Prepared in cooperation with the

West Virginia Department of Health and Human Services and the

West Virginia Department of Environmental Protection

\title{
Hydrogeology and Ground-Water Flow in the Opequon Creek Watershed area, Virginia and West Virginia
}

Scientific Investigations Report 2009-5153 



\section{Hydrogeology and Ground-Water Flow in the Opequon Creek Watershed Area, Virginia and West Virginia}

By Mark D. Kozar and David J. Weary

Prepared in cooperation with the

West Virginia Department of Health and Human Services and the

West Virginia Department of Environmental Protection

Scientific Investigations Report 2009-5153 


\title{
U.S. Department of the Interior \\ KEN SALAZAR, Secretary
}

\section{U.S. Geological Survey \\ Suzette M. Kimball, Acting Director}

\author{
U.S. Geological Survey, Reston, Virginia: 2009 \\ Revised: 2012
}

\begin{abstract}
For more information on the USGS - the Federal source for science about the Earth, its natural and living resources, natural hazards, and the environment, visit http://www.usgs.gov or call 1-888-ASK-USGS

For an overview of USGS information products, including maps, imagery, and publications, visit http://www.usgs.gov/pubprod

To order this and other USGS information products, visit http://store.usgs.gov
\end{abstract}

Any use of trade, product, or firm names is for descriptive purposes only and does not imply endorsement by the U.S. Government.

Although this report is in the public domain, permission must be secured from the individual copyright owners to reproduce any copyrighted materials contained within this report.

Suggested citation:

Kozar, M.D., and Weary, D.J., 2009, Hydrogeology and ground-water flow in the Opequon Creek watershed area, Virginia and West Virginia: U.S. Geological Survey Scientific Investigations Report 2009-5153, 61 p. 


\section{Contents}

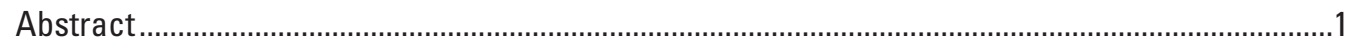

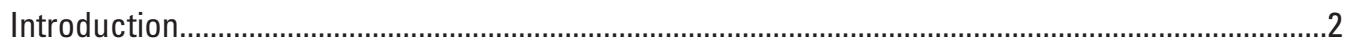

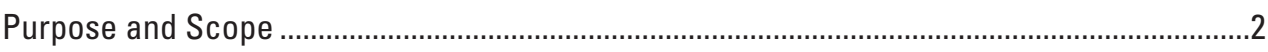

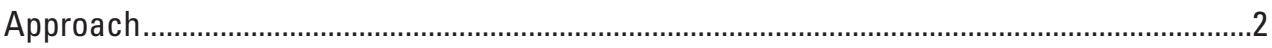

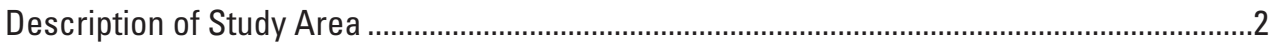

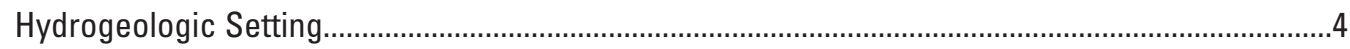

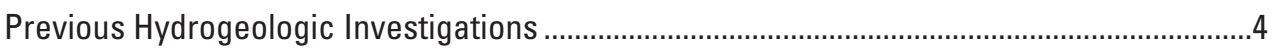

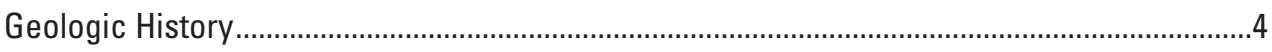

Geology

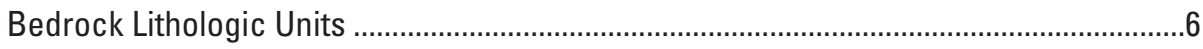

Structural Geology

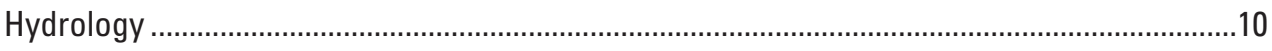

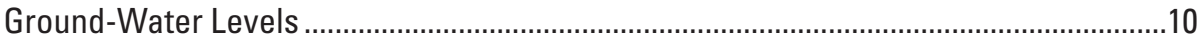

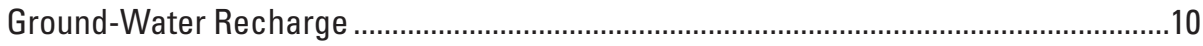

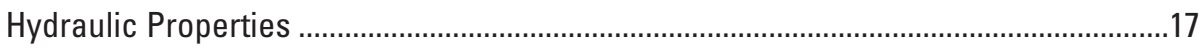

Ground-Water Withdrawals........................................................................................17

Structural and Lithologic Controls on Ground-Water Flow .........................................17

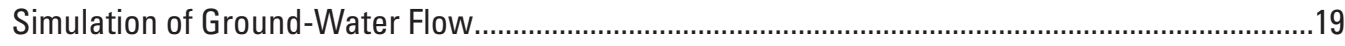

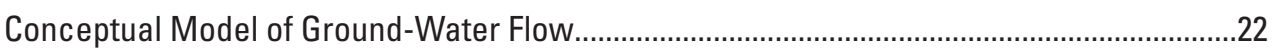

Design and Assumptions ...............................................................................................2

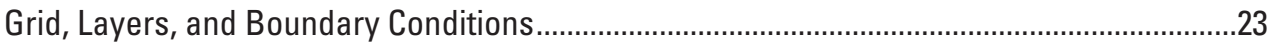

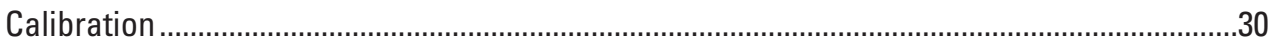

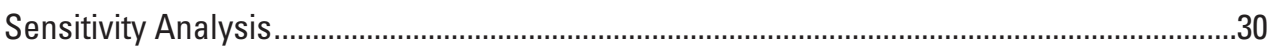

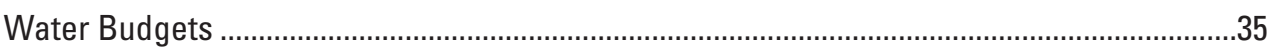

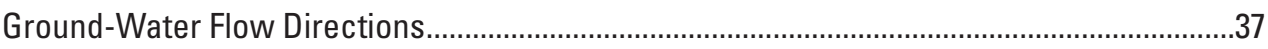

Simulated Flow for Average Conditions.................................................................................

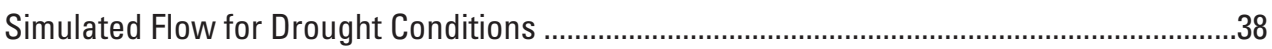

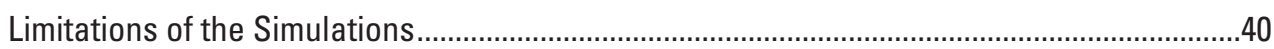

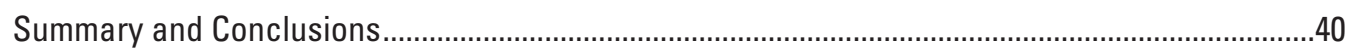

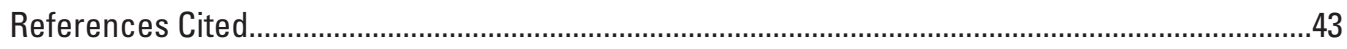

Appendix 1. Water levels and map coordinates for wells used in calibration of the groundwater flow model of the Opequon Creek watershed area, Virginia and West Virginia ...................................................................................................................4

Appendix 2. Data for springs in the Opequon Creek watershed area, Virginia and West Virginia 


\section{Figures}

1. Map showing location of the Opequon Creek watershed area in Virginia and West Virginia

2. (A) Geologic map of, $(B)$ lithologic column for, and $(C)$ geologic sections $A-A^{\prime}$ and

$B$ - $B$ 'through the Opequon Creek watershed area, Virginia and West Virginia.

3-6. Map showing-

3. Location of $(A)$ water-level observation wells used for development and calibration of the ground-water flow model of, and $(B)$ large-capacity production wells, U.S. Geological Survey streamflow-gaging stations, and wastewatertreatment-plant outfalls in, the Opequon Creek watershed area, Virginia and West Virginia

4. Model grid and recharge for the ground-water flow model of the Opequon Creek watershed area, Virginia and West Virginia

5. Distribution of disharge from selected springs and location of known faults and the contact between the Martinsburg Formation and other carbonate bedrock units in the Opequon Creek watershed area, Virginia and West Virginia

6. Digital elevation map of the Opequon Creek watershed area, Virginia and West Virginia

7. Cross section (as shown in figure 6 ) of the model-layer configuration, hydraulic conductivity, inactive cells, and water-table elevation simulated in the ground-water flow model of the Opequon Creek watershed area, Virginia and West Virginia.

8-12. Maps showing-

8. Hydraulic conductivities assigned to the upper layer of the ground-water flow model of the Opequon Creek watershed area, Virginia and West Virginia

9. Hydraulic conductivities assigned to the middle layer of the ground-water flow model of the Opequon Creek watershed area, Virginia and West Virginia .............27

10. Hydraulic conductivities assigned to the lower layer of the ground-water flow model of the Opequon Creek watershed area, Virginia and West Virginia .............28

11. Boundary conditions and the active and inactive cells of the ground-water flow model of the Opequon Creek watershed area, Virginia and West Virginia

12. Subwatersheds for which water-budget analyses were conducted in the Opequon Creek watershed area, Virginia and West Virginia

13-14. Graphs showing-

13. Relation between simulated and observed water levels in 470 observation wells in the Opequon Creek watershed area, Virginia and West Virginia

14. Results of sensitivity analyses of major input parameters for the groundwater flow model of the Opequon Creek watershed area, Virginia and West Virginia

15-16. Maps showing-

15. Simulated potentiometric surface and generalized directions of ground-water flow for average hydrologic conditions in the Opequon Creek watershed area, Virginia and West Virginia.

16. Simulated potentiometric surface and generalized directions of ground-water flow for drought conditions (November 1998-February 2000) in the Opequon Creek watershed area, Virginia and West Virginia 


\section{Tables}

1. (A) Effective-recharge estimates and $(B)$ mean base flow for eight streamflow-gaging stations in the Opequon Creek watershed area, Virginia and West Virginia .....

2. (A) Monthly and annual mean precipitation data for five weather stations in the Opequon Creek watershed area for the period 1971-2000 and $(B)$ historical long-term mean precipitation for Martinsburg, West Virginia, and Winchester, Virginia.

3. Measured values of transmissivity for geologic formations, faults, and fracture zones, and estimated values of hydraulic conductivity assigned to specific layers in the ground-water flow model of the Opequon Creek watershed area, Virginia and West Virginia .....

4. (A) Current withdrawals from large-capacity production wells and $(B)$ return flows from wastewater-treatment plants in the Opequon Creek watershed area, Virginia and West Virginia.

5. Results of geographic information system analyses of the location and discharge of springs with respect to faults, geologic formations, and the contact between carbonate bedrock and the adjacent shale bedrock of the Martinsburg Formation, Opequon Creek watershed area, Virginia and West Virginia.

6. Simulated water budgets for 34 subwatersheds and five streamflow-gaging stations $(A)$ during average hydrologic conditions and $(B)$ during a drought, derived as part of the ground-water flow model of the Opequon Creek watershed area, Virginia and West Virginia. 


\section{Conversion Factors and Datums}

\begin{tabular}{|c|c|c|}
\hline Multiply & By & To obtain \\
\hline \multicolumn{3}{|c|}{ Length } \\
\hline millimeter (mm) & 0.03937 & inch (in.) \\
\hline meter $(\mathrm{m})$ & 3.281 & foot $(\mathrm{ft})$ \\
\hline kilometer (km) & 0.6214 & mile (mi) \\
\hline \multicolumn{3}{|c|}{ Area } \\
\hline square kilometer $\left(\mathrm{km}^{2}\right)$ & 0.3861 & square mile $\left(\mathrm{mi}^{2}\right)$ \\
\hline \multicolumn{3}{|c|}{ Volume } \\
\hline cubic meter $\left(\mathrm{m}^{3}\right)$ & 264.2 & gallon (gal) \\
\hline cubic meter $\left(\mathrm{m}^{3}\right)$ & 35.31 & cubic foot $\left(\mathrm{ft}^{3}\right)$ \\
\hline \multicolumn{3}{|c|}{ Flow rate } \\
\hline cubic meter per day $\left(\mathrm{m}^{3} / \mathrm{d}\right)$ & 35.31 & cubic foot per day $\left(\mathrm{ft}^{3} / \mathrm{d}\right)$ \\
\hline cubic meter per second $\left(\mathrm{m}^{3} / \mathrm{s}\right)$ & 35.31 & cubic foot per second $\left(\mathrm{ft}^{3} / \mathrm{s}\right)$ \\
\hline cubic meter per day $\left(\mathrm{m}^{3} / \mathrm{d}\right)$ & 264.2 & gallon per day (gal/d) \\
\hline cubic meter per second $\left(\mathrm{m}^{3} / \mathrm{s}\right)$ & 22.83 & million gallons per day $(\mathrm{Mgal} / \mathrm{d})$ \\
\hline millimeter per year (mm/yr) & 0.03937 & inch per year (in/yr) \\
\hline \multicolumn{3}{|c|}{ Hydraulic conductivity } \\
\hline meter per day $(\mathrm{m} / \mathrm{d})$ & 3.281 & foot per day (ft/d) \\
\hline \multicolumn{3}{|c|}{ Transmissivity* } \\
\hline meter squared per day $\left(\mathrm{m}^{2} / \mathrm{d}\right)$ & 10.76 & foot squared per day $\left(\mathrm{ft}^{2} / \mathrm{d}\right)$ \\
\hline
\end{tabular}

Vertical coordinate information is referenced to the North American Vertical Datum of 1988 (NAVD 88) unless otherwise noted.

Horizontal coordinate information is referenced to the North American Datum of 1983 (NAD 83).

Altitude, as used in this report, refers to distance above the vertical datum.

*Transmissivity: The standard unit for transmissivity is cubic foot per day per square foot times foot of aquifer thickness $\left[\left(\mathrm{ft}^{3} / \mathrm{d}\right) / \mathrm{ft}^{2}\right] \mathrm{ft}$. In this report, the mathematically reduced form, foot squared per day $\left(\mathrm{ft}^{2} / \mathrm{d}\right)$, is used for convenience and expressed in the metric equivalent of square meters per day $\left(\mathrm{m}^{2} / \mathrm{d}\right)$. 


\title{
Hydrogeologic Setting and Ground-Water Flow in the Opequon Creek watershed area, Virginia and West Virginia
}

\author{
By Mark D. Kozar and David J. Weary
}

\section{Abstract}

Due to increasing population and economic development in the northern Shenandoah Valley of Virginia and West Virginia, water availability has become a primary concern for water-resource managers in the region. To address these issues, the U.S. Geological Survey (USGS), in cooperation with the West Virginia Department of Health and Human Services and the West Virginia Department of Environmental Protection, developed a numerical steady-state simulation of ground-water flow for the 1,013-square-kilometer Opequon Creek watershed area. The model was based on data aggregated for several recently completed and ongoing USGS hydrogeologic investigations conducted in Jefferson, Berkeley, and Morgan Counties in West Virginia and Clarke, Frederick, and Warren Counties in Virginia. A previous detailed hydrogeologic assessment of the watershed area of Hopewell Run (tributary to the Opequon Creek), which includes the USGS Leetown Science Center in Jefferson County, West Virginia, provided key understanding of ground-water flow processes in the aquifer.

The ground-water flow model developed for the Opequon Creek watershed area is a steady-state, three-layer representation of ground-water flow in the region. The primary objective of the simulation was to develop water budgets for average and drought hydrologic conditions. The simulation results can provide water managers with preliminary estimates on which water-resource decisions may be based.

Results of the ground-water flow simulation of the Opequon Creek watershed area indicate that hydrogeologic concepts developed for the Hopewell Run watershed area can be extrapolated to the larger watershed model. Sensitivity analyses conducted as part of the current modeling effort and geographic information system analyses of spring location and yield reveal that thrust and cross-strike faults and low-permeability bedding, which provide structural and lithologic controls, respectively, on ground-water flow, must be incorporated into the model to develop a realistic simulation of groundwater flow in the larger Opequon Creek watershed area.

In the model, recharge for average hydrologic conditions was $689 \mathrm{~m}^{3} / \mathrm{d} / \mathrm{km}^{2}$ (cubic meters per day per square kilometer) over the entire Opequon Creek watershed area. Mean and median measured base flows at the streamflow-gaging station on the Opequon Creek near Martinsburg, West Virginia, were 604,384 and $349,907 \mathrm{~m}^{3} / \mathrm{d}$ (cubic meters per day), respectively. The simulated base flow of $432,834 \mathrm{~m}^{3} / \mathrm{d}$ fell between the mean and median measured stream base flows for the station. Simulated base-flow yields for subwatersheds during average conditions ranged from 0 to $2,643 \mathrm{~m} / \mathrm{d} / \mathrm{km}^{2}$, and the median for the entire Opequon Creek watershed area was $557 \mathrm{~m}^{3} / \mathrm{d} / \mathrm{km}^{2}$.

A drought was simulated by reducing model recharge by 40 percent, a rate that approximates the recharge during the prolonged 16-month drought that affected the region from November 1998 to February 2000. Mean and median measured streamflows for the Opequon Creek watershed area at the Martinsburg, West Virginia, streamflow-gaging station during the 1999 drought were 341,098 and 216,551 $\mathrm{m}^{3} / \mathrm{d}$, respectively. The simulated drought base flow at the station of $252,356 \mathrm{~m}^{3} / \mathrm{d}$ is within the range of flows measured during the 1999 drought. Recharge was $413 \mathrm{~m} / \mathrm{d} / \mathrm{km}^{2}$ over the entire watershed during the simulated drought, and was $388 \mathrm{~m} / \mathrm{d} / \mathrm{km}^{2}$ at the gaging station. Simulated base-flow yields for drought conditions ranged from 0 to $1,865 \mathrm{~m}^{3} / \mathrm{d} / \mathrm{km}^{2}$ and averaged $327 \mathrm{~m}^{3} / \mathrm{d} / \mathrm{km}^{2}$ over the entire Opequon Creek watershed.

Water budgets developed from the simulation results indicate a substantial component of direct ground-water discharge to the Potomac River. This phenomenon had long been suspected but had not been quantified. During average conditions, approximately $564,176 \mathrm{~m}^{3} / \mathrm{d}$ of base flow discharges to the Potomac River. An additional 124,379 $\mathrm{m}^{3} / \mathrm{d}$ of ground water is also estimated to discharge directly to the Potomac River and represents approximately 18 percent of the total discharge to the Potomac River. 


\section{Introduction}

The study area for this investigation is the Opequon Creek watershed area in the northern Shenandoah Valley of Virginia and West Virginia and the Eastern Panhandle of West Virginia. The study area (fig. 1) encompasses approximately $1,013 \mathrm{~km}^{2}$ and includes both the Opequon Creek watershed $\left(855 \mathrm{~km}^{2}\right)$ and those of several smaller, mostly unnamed tributary streams that discharge directly to the Potomac River in the northern portion of the study area $\left(158 \mathrm{~km}^{2}\right)$. The region has experienced rapid population growth and associated economic development over the last 20 years. This increased growth has placed an ever-increasing demand on available ground- and surface-water resources. Local, county, and State water managers have recognized the importance of effective management of the abundant but finite ground-water resources of the region. Effective management of ground-water resources requires a thorough knowledge of the availability of groundwater resources not only during average climatic conditions but also, more importantly, during the critical low-water-table and streamflow conditions that occur during droughts. The 16-month drought that affected the region from November 1998 through February 2000 exposed the limits of water availability and was a driving force behind the need for accurate assessments of water resources in the region.

\section{Purpose and Scope}

This report presents results of a steady-state simulation of ground-water flow in the Opequon Creek watershed area in the northern Shenandoah Valley of Virginia and West Virginia. The model was developed by extrapolating the conceptual model (Kozar and others, 2007) of ground-water flow developed for the smaller Hopewell Run watershed area $\left(52 \mathrm{~km}^{2}\right)$ (fig. 1) to the much larger Opequon Creek watershed area $\left(1,013 \mathrm{~km}^{2}\right)$. The resulting model was used to develop a budget of available ground-water resources and to assess the potential effects of drought on water availability within the watershed. The report describes the hydrogeology of the study area, documents the development of the ground-water flow model, presents the results of water-budget analyses, and quantifies simulated streamflow under both average and drought conditions.

\section{Approach}

Various methods were used to develop the numerical ground-water flow model of the Opequon Creek watershed area. Extensive aquifer tests conducted in Berkeley and Jefferson Counties, West Virginia (McCoy and others, 2005a, 2005b), and in a recent investigation completed at the USGS Leetown Science Center (Kozar and others, 2007, 2008) provided the hydraulic data (transmissivity, hydraulic conductivity, and storativity) and the conceptual model of groundwater flow needed to develop and calibrate a numerical ground-water flow model of the area. Eight USGS streamflowgaging stations (table 1) provided base-flow data to aid in calibrating simulated ground-water flows in the model. Base-flow surveys conducted in the region in 2005 and 2006 (Evaldi and Paybins, 2006a, 2006b) helped to identify potential gaining and losing reaches in the watershed and subwatersheds with either abnormally high or low base-flow yields. Base flow is streamflow provided by ground-water discharge. Recharge to the study area was estimated by analyzing streamflow hydrographs (Rutledge, 1998) for the eight gaging stations in the watershed and provided the primary input to the model. Ground-water levels measured at 420 wells in the study area were retrieved from the USGS Ground-Water Site Inventory (GWSI) database and used for calibration of ground-water levels in the model. Aquifer tests conducted in the area as part of previous studies (McCoy and others, 2005a, 2005b) provided data on the hydraulic properties of the aquifer needed for model development and calibration.

The computer software package Visual MODFLOW, version 4.0.0.131 (Waterloo Hydrogeologic, Inc., 2004), was used to develop a steady-state ground-water flow model of the Opequon Creek watershed area. Visual MODFLOW is a commercially derived graphical user interface to the USGS MODFLOW 2000 three-dimensional finite-difference groundwater modeling software (Harbaugh and others, 2000) and to MODPATH (Pollock, 1998), a USGS particle-tracking software package. MODFLOW was used to simulate groundwater levels and develop a water budget for the Opequon Creek watershed area.

\section{Description of Study Area}

The study area is an approximately $1,013-\mathrm{km}^{2}$ region of the northern Shenandoah Valley in Virginia and West Virginia (fig. 1). The region is part of the broader Great Valley of the Valley and Ridge Physiographic Province (Fenneman, 1938), which extends from New York to Alabama. Therefore, it is assumed that methods developed and tested for this and previous studies in the area are transferable to the broader Great Valley region. Major population centers in the region include Martinsburg, West Virginia, and Winchester, Virginia (fig. 1). The major tributary draining the study area is Opequon Creek (drainage area of $855 \mathrm{~km}^{2}$ ), which discharges to the Potomac River. Numerous smaller tributaries, including Hopewell Run, drain to Opequon Creek, and a few smaller streams (drainage areas totaling $158 \mathrm{~km}^{2}$ ) drain directly to the Potomac River. Elevation in the study area ranges from a maximum of approximately $390 \mathrm{~m}$ along North Mountain in the western part of the study area to a minimum of $130 \mathrm{~m}$ at the mouth of Opequon Creek. 


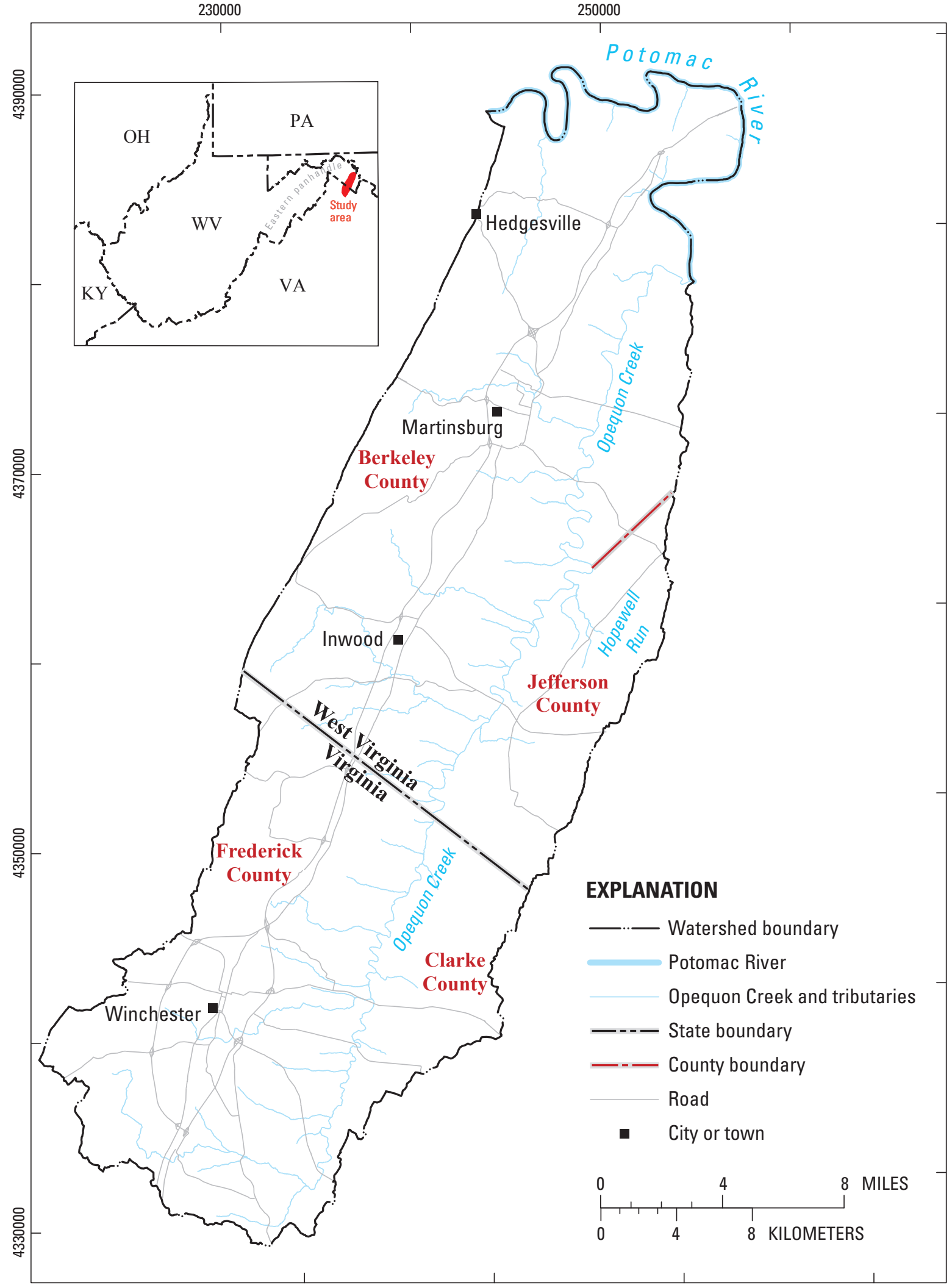

Base from U.S. Geological Survey digital data, Universal Transverse Mercator Projection, Zone 18, NAD 83.

Figure 1. Location of the Opequon Creek watershed area in Virginia and West Virginia. (Opequon Creek forms the boundary between Berkeley and Jefferson Counties in West Virginia and between Clarke and Frederick Counties in Virginia.) 
Hydrogeologic Setting and Ground-Water Flow in the Opequon Creek Watershed Area, Virginia and West Virginia

\section{Hydrogeologic Setting}

The study area is dominated by karst terrain, consisting of Cambro-Ordovician-age limestones and dolomites in a broad synclinal trough, which is bisected by the younger late-Ordovician-age Martinsburg Formation. This unit is a predominantly brown shale, which crops out in the center of the valley (fig. 2a). Siliciclastic rocks border the study area along a series of high-angle thrust faults along North Mountain to the west. Bedrock ridges form in the low-permeability Conococheague Limestone on the eastern side of the syncline. Although the study area is karstic, sinkholes are sparse and typically are small, less than $10 \mathrm{~m}$ in diameter. Caves are also sparse and limited in length and width. Within the karst aquifer system, diffuse components of ground-water flow provide most of the storage.

\section{Previous Hydrogeologic Investigations}

The relation between geology and ground-water supply and quality in the study area was first discussed by Jeffords (1945a, 1945b). Graeff (1953) and Beiber (1961) explained the lithologic control of carbonate units on the quality and quantity of ground water, and on the direction of flow in the aquifers of Jefferson and Berkeley Counties, West Virginia. Large springs discharging more than $545 \mathrm{~m}^{3} / \mathrm{d}(1,000 \mathrm{gal} / \mathrm{min})$ from these carbonate units were correlated with the faults in the area by Hobba and others (1972). Taylor (1974) concluded that systematic fracturing of the carbonate bedrock, attributed to a four-phase deformation history, is partially evident from topographic analysis of the area. He found that well yields and spring locations in lowland areas are related to structural features, such as joints, faults, and fractures, that allow large quantities of ground water to flow downgradient. Seasonal and annual fluctuations in ground-water storage and base-flow discharge to streams associated with these features can be large (Hobba, 1976, 1981). Estimates of aquifer transmissivity for the fractured carbonate rocks from Kozar and others (1991) and Shultz and others (1995) ranged over four orders of magnitude $\left(0.1-2,000 \mathrm{~m}^{2} / \mathrm{d}\right)$. Preferential flow in the direction of strike was verified by the dye-tracing work of Jones (1991), Kozar and others (1991), and Shultz and others (1995). Previous dye-tracing work in the Hopewell Run watershed area by Jones and Deike (1981) led to the conclusion that the aquifer is characterized by steeply dipping bedding planes with a diffuse network of fractures that may retard travel times and force circulation to depths below those common in other karst systems. McCoy and Kozar (2007b) found that vertical flow of ground water in the Great Valley was downgradient along continuous interconnected fractures in the direction of bedding. Ground water is eventually forced to the surface along structural offsets perpendicular to strike. Structural geologic features, especially thrust faults and cross-strike faults, are important controls on ground-water flow and coincide with many of the larger solution conduits in the region (Kozar and others, 2007, 2008). Lithologic controls, especially low-permeability units such as the Conococheague Limestone and Martinsburg Formation, are equally important, as they act as barriers to ground-water flow, forcing water to flow along solutionally enlarged bedding planes, thrust faults, and crossstrike faults. In nearby Frederick County, Virginia, Harlow and others (2005) modified the conceptual model of Wolfe and others (1997) to describe the influence of structural features on karst development at moderate depths. An equivalent-porousmedium (EPM) finite-difference model for the Opequon Creek watershed was first developed by Early (2005), but simulation of discharge at springs by use of pumping nodes produced unrealistic cones of depression around the springs. The effort did, however, illustrate the potential utility of EPM simulations for assessing regional water budgets. A regional ground-water flow model developed for the entire Shenandoah River watershed (Yager, 2008) was used to evaluate the effect of complex geologic structure on regional patterns of ground-water flow to production wells. Dealing with different geologic structure in various ways produced slightly different zones of contribution to simulated production wells, but overall water budgets were similar.

Ground-water flow patterns in the Great Valley are complex. The once flat-lying sedimentary rocks have been folded, faulted, and intensely weathered such that a variably thick layer of regolith overlies steeply dipping, deformed bedrock units. Recharge in the form of infiltration of precipitation initially moves into the regolith, where much of it is stored. Water moves to the underlying bedrock by way of leakage to open fractures, faults, and bedding planes or by direct runoff into surficial karst features. Flow in the bedrock is controlled by the orientation and connectivity of the fracture system and the location of solution-enlarged conduits. Relict structure in the regolith and continuous bedding planes apparently force flow parallel to regional gradients (Jones, 1991). Frazier and others (1988) conducted a detailed surface-water assessment at the USGS Leetown Science Center and adjacent property in the Hopewell Run watershed using watershed models to assess flooding potential and long-term stability of engineered ponds proposed for construction.

\section{Geologic History}

The sedimentary rocks in the Opequon Creek watershed area were deposited in chiefly shallow marine environments over about a 200-million-year (m.y.) period of relative tectonic quiescence from the Late Cambrian (about 540 m.y. ago) into the Mississippian Period (about 340 m.y. ago). From about 340 m.y. to about 280 m.y. ago, continental collision between North America and Africa, the Alleghenian orogeny, produced most of the folds, faults, and joints seen in the Great Valley today. Earlier episodes of tectonism seen in rocks east of the Blue Ridge, such as the Taconic and Acadian orogenies, apparently did not affect the rocks of the Great Valley (Southworth and others, 2006). Post-Paleozoic erosion has removed younger sediments to expose Cambrian- and Ordovician-age rocks at the land surface today. 


\section{Geology}

Lithology and bedrock structure are important controls on ground-water flow. Low-permeability lithologic units such as the Martinsburg Formation and Conococheague Limestone act as barriers to ground water flowing across the strike of the bedding. This retardation of cross-strike flow is especially pronounced where the bedding dips at steep angles or where the lower permeability formations crop out. Geologic structures that disrupt the rocks in cross-strike directions, especially highly permeable fault and fracture zones, provide avenues through which ground water can flow laterally across or through strata with low primary permeability. Solution conduits form along strike-parallel thrust faults, especially where downgradient flow is forced into these features by lower permeability bedrock. These structural features act as drains for the broader network of diffuse-flow fractures in the aquifer and are especially prominent along the geologic contacts between carbonate strata and the much lower permeability Martinsburg Formation.

\section{Bedrock Lithologic Units}

The bedrock of the Opequon Creek watershed area (fig. 2a) is composed of predominantly fractured limestone and dolomite of the Upper Cambrian Elbrook Formation and Lower Ordovician and Upper Cambrian Conococheague Limestone; the Lower Ordovician Stonehenge Limestone, Rockdale Run Formation, and Pinesburg Station Dolomite; and the Middle Ordovician New Market and Chambersburg Limestones. A large portion of the Opequon Creek watershed area is underlain by clastic rocks of the Upper and Middle Ordovician Martinsburg Formation, the youngest bedrock lithologic unit in the model area. A thin band of Silurian and Devonian clastic rocks crops out along much of the northwestern boundary of the watershed in the Little North Mountain fault zone. The stratigraphic relations, lithologies, and relative thicknesses of the Cambrian and Ordovician rock units are shown in figure $2 b$.

The Elbrook Formation, the oldest unit exposed in the Opequon Creek watershed area, is found in a thick outcrop belt that parallels the western edge of the study area (fig. 2a). The Elbrook is composed of interbedded limestone, dolostone, and shale. The limestone, which may be thinly to moderately bedded, contains algal bioherms, intraformational conglomerates, and dolomite mottling. The dolostone is commonly moderately bedded; a distinctive yellowish weathering of thinly bedded laminated dolostone appears shaly in weathered outcrops. The Elbrook Formation in the watershed is about $700 \mathrm{~m}$ thick.

The Conococheague Limestone is exposed in a thick outcrop belt along the western side and in several folds in the northern and eastern part of the Opequon Creek watershed area (fig. 2a). The Conococheague Limestone is chiefly thickbedded, light-gray limestone deposited in upward-shallow peritidal cycles capped by laminated dolomite beds. Typical cycle thicknesses range from 2 to $12 \mathrm{~m}$. Some beds contain rip-up clasts, forming flat-pebble, edgewise conglomerates. The quartz-sandstone-rich, basal Big Springs Station Member of the Conococheague Limestone is resistant to weathering and produces prominent topographic ridges that serve as markers for the contact with the underlying Elbrook Formation, which is commonly obscured by soil. Conodont biostratigraphy suggests that the Cambrian-Ordovician boundary is within the Conococheague Limestone near the upper formational contact (Harrris and others, 1994). The Conococheague Limestone is about $850 \mathrm{~m}$ thick in this part of the Great Valley.

The Ordovician Stonehenge Limestone occurs in outcrop belts in approximately the center of each of the east and west limbs of the Massanutten synclinorium in the Opequon Creek watershed area (fig. 2a). The Stonehenge Limestone is a thick to massive-bedded (with thin interbeds), dark-gray, siliceous limestone. The silt is concentrated in wispy laminae that commonly weather in raised-relief natural exposures. The silt content of the rock has allowed a pervasive axial planar cleavage, related to Alleghenian folding, to be produced. In some exposures the cleavage is so penetrative that it has obscured or obliterated the bedding planes. In such areas, the cleavage probably has a greater effect on the hydrologic properties of the rocks than the bedding. The lower part of the Stonehenge Limestone is the Stoufferstown Member. This member is distinguished by the anastomosing, crinkly, siliceous laminae permeating the limestone, and commonly forms distinct strikeparallel linear ridges and fins in outcrop. The Stonehenge Limestone is about $198 \mathrm{~m}$ thick.

The Rockdale Run Formation and the superjacent Pinesburg Station Dolomite were treated as one unit for this study. The Rockdale Run Formation is composed of thick and medium-bedded, light-gray limestone and dolomite in cyclic, peritidal deposits that resemble those in the Conococheague Limestone. It is commonly lighter in color and less cleaved than the underlying Stonehenge Limestone. The Pinesburg Station Dolomite is thick-bedded and weathers light gray to buff. It ranges from 0 to $122 \mathrm{~m}$ thick, whereas the Rockdale Run Formation is commonly about $460 \mathrm{~m}$ thick in this part of the Great Valley (Dean and others, 1990).

Because of the regional scale of this study, the relatively thin Middle Ordovician limestones overlying the Pinesburg Station Dolomite were combined into one map unit (Oeln). In Virginia, these units are the New Market, Lincolnshire, and Edinburg Limestones. In West Virginia, the facies that defines the Lincolnshire is absent, and the rocks above the New Market Limestone that are equivalent to the Edinburg lithology are called the Chambersburg Limestone. These limestones are exposed in two belts flanking the core of the Massanutten synclinorium, which is occupied by the superjacent shales and sandstones of the Martinsburg Formation (fig. 2a). The New Market Limestone lies unconformably above the Pinesburg Station Dolomite. The New Market Limestone is a very pure, dove-gray, lime mudstone. It is quarried extensively at various locations in the region. The New Market is the most soluble 


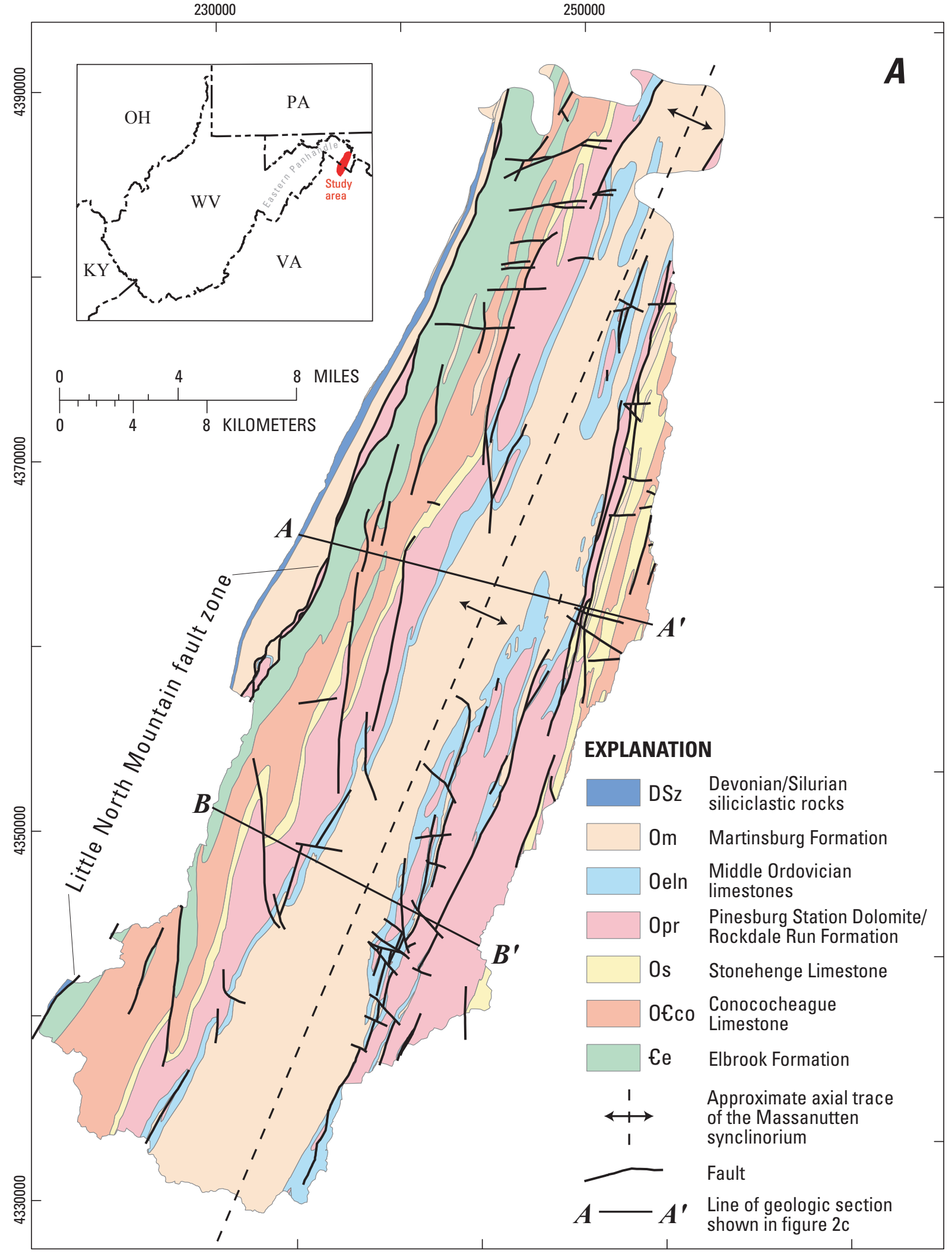

Base from U.S. Geological Survey digital data, Universal Transverse Mercator Projection, Zone 18, NAD 83.

Figure 2. (A) Geologic map of, $(B)$ lithologic column for, and $(C)$ geologic sections $A-A^{\prime}$ and $B$ - $B^{\prime}$ through the Opequon Creek watershed area, Virginia and West Virginia. 


\section{EXPLANATION}
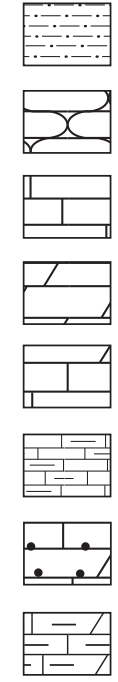

Shale and siltstone

Knobby limestone and calcareous shale

Limestone

Dolomite

Interbedded limestone and dolomite

Shaly limestone

Sandy interbedded dolomite and limestone

Shaly limestone and dolomite

Vertical scale

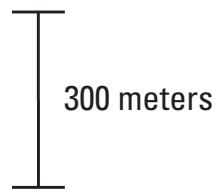

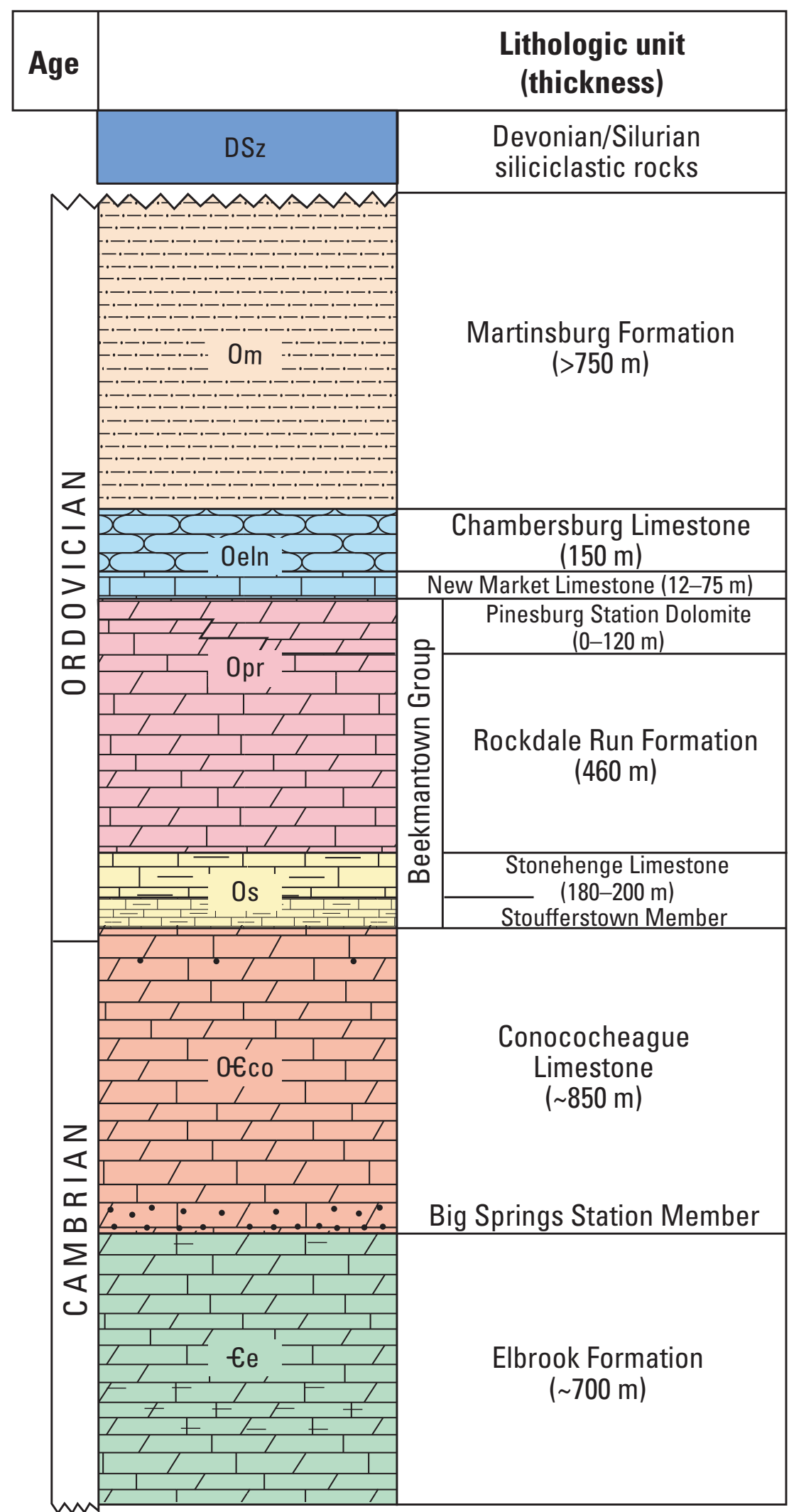

Figure 2. (A) Geologic map of, $(B)$ lithologic column for, and $(C)$ geologic sections $A-A^{\prime}$ and $B-B^{\prime}$ through the Opequon Creek watershed area, Virginia and West Virginia.-Continued 

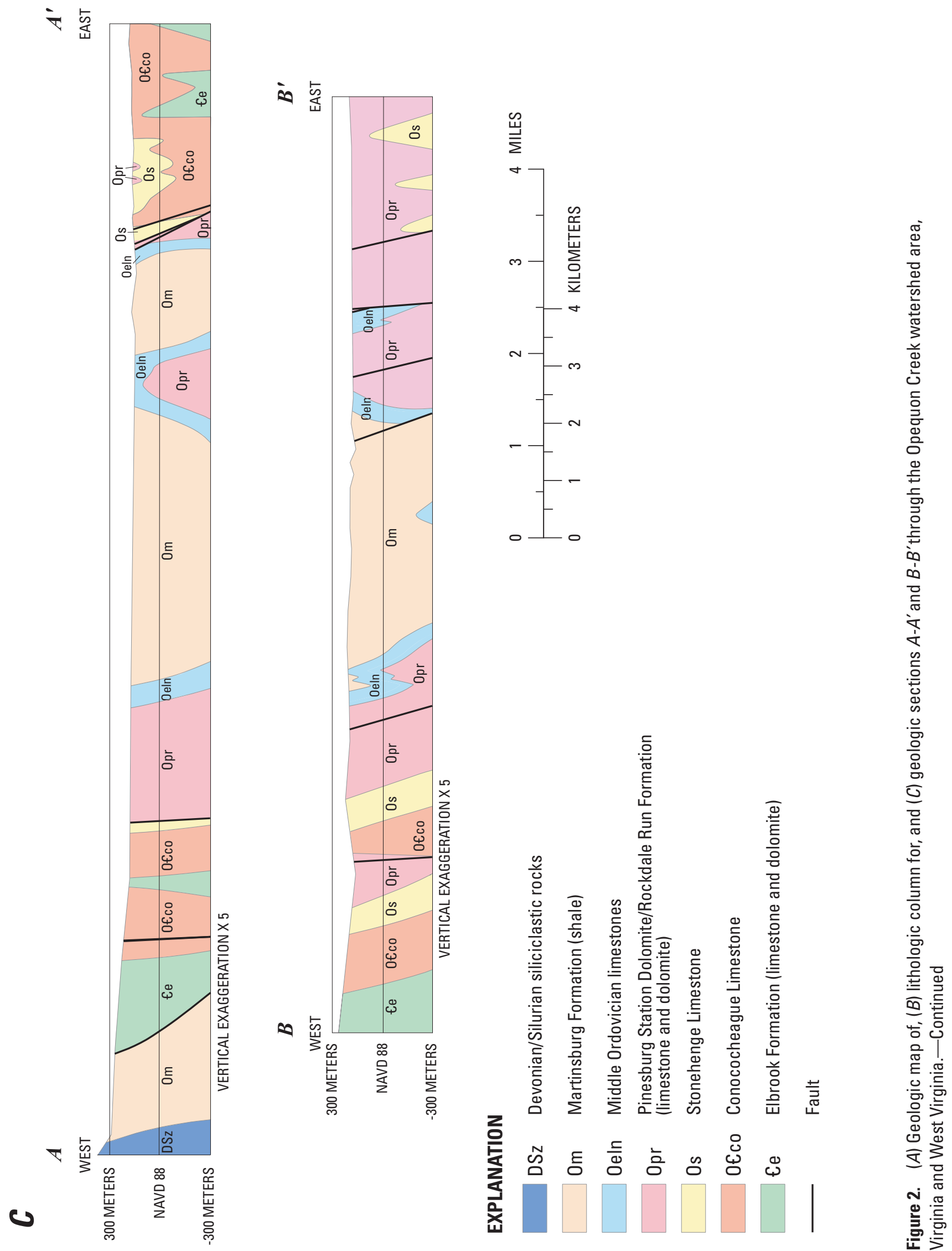
unit in the study area and is the most likely to develop karst features. The other Middle Ordovician limestones, although less soluble than the New Market, constitute a highly soluble outcrop belt between the Pinesburg Station Dolomite below and the shale of the Martinsburg Formation above. The Middle Ordovician limestones are about $200 \mathrm{~m}$ thick.

The Martinsburg Formation, the youngest stratigraphic unit in the study area, chiefly occupies a large area along the axis of the Massanutten synclinorium (fig. 2a, 2c). A large outcrop belt also exists along the western margin of the Opequon Creek watershed area in the Little North Mountain fault zone. Several thin belts along narrow thrust-fault-truncated synclines also occur in the east-central part of the watershed area (fig. 2a, 2c). The Martinsburg Formation contains mediumgray to dark-gray and light-olive-gray shale and siltsone, commonly weathering to a light yellowish or orange-brown color. The lower several hundred meters may be composed of calcareous shales of the Stickley Run Member (Orndorff and others, 1999). The Martinsburg Formation also contains beds of medium-gray to olive-gray graywacke. Graywacke is more abundant and more thickly bedded higher in the section, where it forms conspicuous ribs in creek beds and may comprise as much as 30 percent of some intervals that are several hundred meters thick. This occurs more commonly in the southern part of the watershed, where the Massanutten synclinorium is plunging to the south. Axial planar cleavage is well developed along folds and in places obscures the bedding. As a primarily siliciclastic unit, the Martinsburg Formation is the only bedrock unit in the study area that does not have karst features. The total thickness of the Martinsburg Formation in the study area exceeds $760 \mathrm{~m}$. The youngest rocks in the study area are a thin belt of undifferentiated clastic rocks of Silurian and Devonian age that are exposed along Little North Mountain at the western edge of the Opequon Creek watershed area. These rocks are chiefly quartz arenites, orthoquartzites, and shales.

\section{Structural Geology}

The geologic structure of the Opequon Creek watershed area is complex, with numerous thrust faults oriented parallel or subparallel to the regional bedrock strike and fault traces trending approximately N. $20^{\circ}$ E. Cross-strike longitudinal and oblique faults also occur, with traces at attitudes of approximately N. $80^{\circ} \mathrm{W}$. and N. $65^{\circ}$ E., respectively. The rocks are tectonically deformed, and the numerous upright and overturned folds in the area affect ground-water flow.

Structurally, the Opequon Creek watershed area lies almost entirely within the Massanutten synclinorium, a megascale downfold with many small folds and faults superimposed upon it, which locally forms the Great Valley. Within the watershed, the synclinorium plunges gently toward the south and is slightly asymmetrical, with the eastern limb steeper than the western. Most of the main stem of Opequon Creek is located just east of the fold axis, flowing north-northeast near or on the contact between the clastic rocks of the Martinsburg
Formation and the carbonates of the Middle Ordovician limestones (see geologic map and cross sections, figures $2 \mathrm{a}$ and 2c). East of the synclinorium axis, beds tend to dip steeply and are overturned in some areas. The overturned folds verge to the northwest with limbs dipping steeply toward the southeast (fig. 2c). Folds on the western limb of the synclinorium tend to plunge toward the southwest; those on the eastern limb plunge toward the northeast.

Thrust faults, which moved rocks from the southeast up and over rocks to the northwest, form the dominant fracture pattern in the Opequon Creek watershed area. They are more common in the carbonate rocks on the eastern side of the synclinorium (fig. 2a, 2c); on the western side, most thrust movement has occurred along the Little North Mountain fault zone.

A series of several south-to-north-trending faults are important features found on the west side of the synclinorium. These are reverse faults associated with large, failed folds and may focus ground-water flow out of the large southwardplunging synclines to the south and across the structural grain toward the axis of the synclinorium.

Although many cross-strike faults have been mapped both on the eastern and western sides of the watershed, they are more common on the eastern side (fig. 2a). These faults are commonly only a few miles in extent, but are probably important for guiding ground-water flow across the strike of bedding and possibly across thrust faults. They can be either normal or reverse faults and most are near vertical in attitude. (See Orndorff (1992) for a discussion of cross-strike faults in the Great Valley.) There are probably a number of faults of each style in the belt of Martinsburg Formation exposed along the axis of the synclinorium, but they are unmapped because they are not exposed and lack good marker horizons within the Martinsburg Formation.

The pattern of distinct cross-strike faults, clearly seen in the topographic expression of the weathered land surface over the Martinsburg Formation, suggests that the core of the Massanutten synclinorium in this part of the Great Valley (north of Massanutten Mountain and south of the Potomac River) achieves its apparent southward plunge through many normal faults, which step down to the south. This is also manifested by the relative widening of the map pattern of the synclinorium to the south.

At a local scale, bedding planes and joints are the dominant fracture type in the Opequon Creek watershed area. The predominant trends for bedding attitude are strikes to the north-northeast and dips to the southeast or northwest. On the eastern side of the Massanutten synclinorium the dip is mostly steep and to the northwest, although some areas are overturned and dip very steeply to the southeast. On the western side of the synclinorium the dip tends to be to the southeast and, on average, less steep than on the eastern side.

Joints - fractures in the rock produced by tectonic stress - are found in all of the bedrock units in the Opequon Creek watershed area. The most common joint-plane attitudes are (1) oriented approximately normal to the strike of bedrock 
(dip joints), (2) oriented approximately parallel to the strike of bedrock (longitudinal joints), and (3) oriented in the directions of shear (at acute angles bisected by the plane of the dip joints). Most of the joints are non-throughgoing - that is, they do not penetrate continuously across lithologic boundaries. Locally, some joints are throughgoing, and may be important avenues for ground-water flow.

\section{Hydrology}

Ground water in the study area occurs predominantly in diffuse fractures. Water that flows through the intricate network of lower permeability diffuse fractures is collected over a broad area in higher permeability conduit drains that primarily coincide with the major thrust, normal, and crossstrike faults of the region. Earlier investigators who developed conceptual models of ground-water flow in the area (Kozar and others, 1991; Shultz and others, 1995) recognized the importance of solutionally enlarged bedding planes in governing ground-water flow. The importance of cross-strike faults or other complex geologic structures, such as overturned or tightly folded structures, in controlling ground-water flow was not fully realized until it was viewed in the context of recent work (McCoy and others, 2005a, 2005b), and of the data collected for this investigation. The conceptual model of groundwater flow in the region was more fully documented in recent investigations completed in the Hopewell Run watershed area (Kozar and others, 2007, 2008).

\section{Ground-Water Levels}

A search of ground-water levels available for the study area was made by querying the GWSI database. A total of 513 water levels were available for development and calibration of the ground-water flow model of the Opequon Creek watershed area. Unfortunately, the data were collected over a 40 -year period that includes both high and low ground-waterlevel conditions. Also, some of the data were considered to be questionable as a result of poor location information, pumping prior to measurement of the water level, poor well yield, or other factors. After approximately 10 percent of obvious outlier data were eliminated, 470 sites (app. 1) remained for final calibration and development of the ground-water flow model. The data provided good areal coverage of the Opequon Creek watershed area (fig. 3a), and overall provided a large data set of ground-water levels to which the ground-water flow model could be calibrated. Because the data represented measurements over a broad range of hydrologic conditions, the ground-water flow model was calibrated to the average ground-water level represented by the data throughout the range of altitude for the watershed. Production wells within the Opequon Creek watershed area are shown in figure $3 \mathrm{~b}$.

\section{Ground-Water Recharge}

An accurate assessment of ground-water recharge in the study area is needed to develop a realistic ground-water flow model. Streamflow data for the Opequon Creek watershed area were obtained from eight USGS streamflow-gaging stations (fig. 3b). Hydrographs of the streamflow data from six of the gaging stations were analyzed using the Rorabaugh method (Rutledge, 1998) to estimate effective ground-water recharge rates for the watershed. Effective recharge was estimated using the USGS hydrograph analysis software RORA and RECESS (Rutledge, 1998). Recharge ranged from 123 to $420 \mathrm{~mm} / \mathrm{yr}$ (table 1). The variability in recharge is primarily a function of the composition of bedrock within the respective watersheds for which the estimates are made. Recharge in the model was assigned on the basis of analyses of streamflow records but was modified on the basis of model-calibration results to account for differences in lithology and density of cross-strike faults.

Recharge rates tend to be lower in areas dominated by shale than in areas with a higher proportion of limestone, especially the more permeable limestones such as those of the Stonehenge Limestone, the Rockdale Run Formation, and the Middle Ordovician limestone formations (fig. 2). As a result, three different recharge rates were used to simulate ground-water flow in the model representing this variability in recharge for the region. The highest recharge rate $(390 \mathrm{~mm} / \mathrm{yr})$ was applied to the northern part of the study area, north of Martinsburg (fig. 4). This area has experienced intensive downcutting of bedrock by the Potomac River and is characterized by a higher density of cross-strike faults (fig. 2) than other areas within the watershed. The higher density of crossstrike faults along with the downcutting results in greater depths to ground water and greater ground-water recharge than in other parts of the watershed. A recharge value of $280 \mathrm{~mm} /$ yr was assigned to carbonate bedrock formations within the model; a value of $150 \mathrm{~mm} / \mathrm{yr}$ was assigned to the area underlain by the Martinsburg Formation.

Precipitation records (National Oceanic and Atmospheric Administration, 2002a, 2002b) from five National Oceanic and Atmospheric Administration (NOAA) weather stations and from the airport at Winchester, Virginia, indicate long-term average annual precipitation of 925 to $1,026 \mathrm{~mm} / \mathrm{yr}$ (table 2). The long-term average precipitation for the region was used to develop the water budget for the Opequon Creek watershed area. Precipitation is the major input of water into the study area. The only interbasin transfer of water into the watershed occurs as a result of the wastewater-treatment return flow from Winchester, Virginia, which obtains water from an intake on the Shenandoah River. Although the interbasin transfer of water is negligible in relation to the recharge from precipitation, it was factored into the water budget and accounted for by the streamflow data from USGS streamflow-gaging stations. 


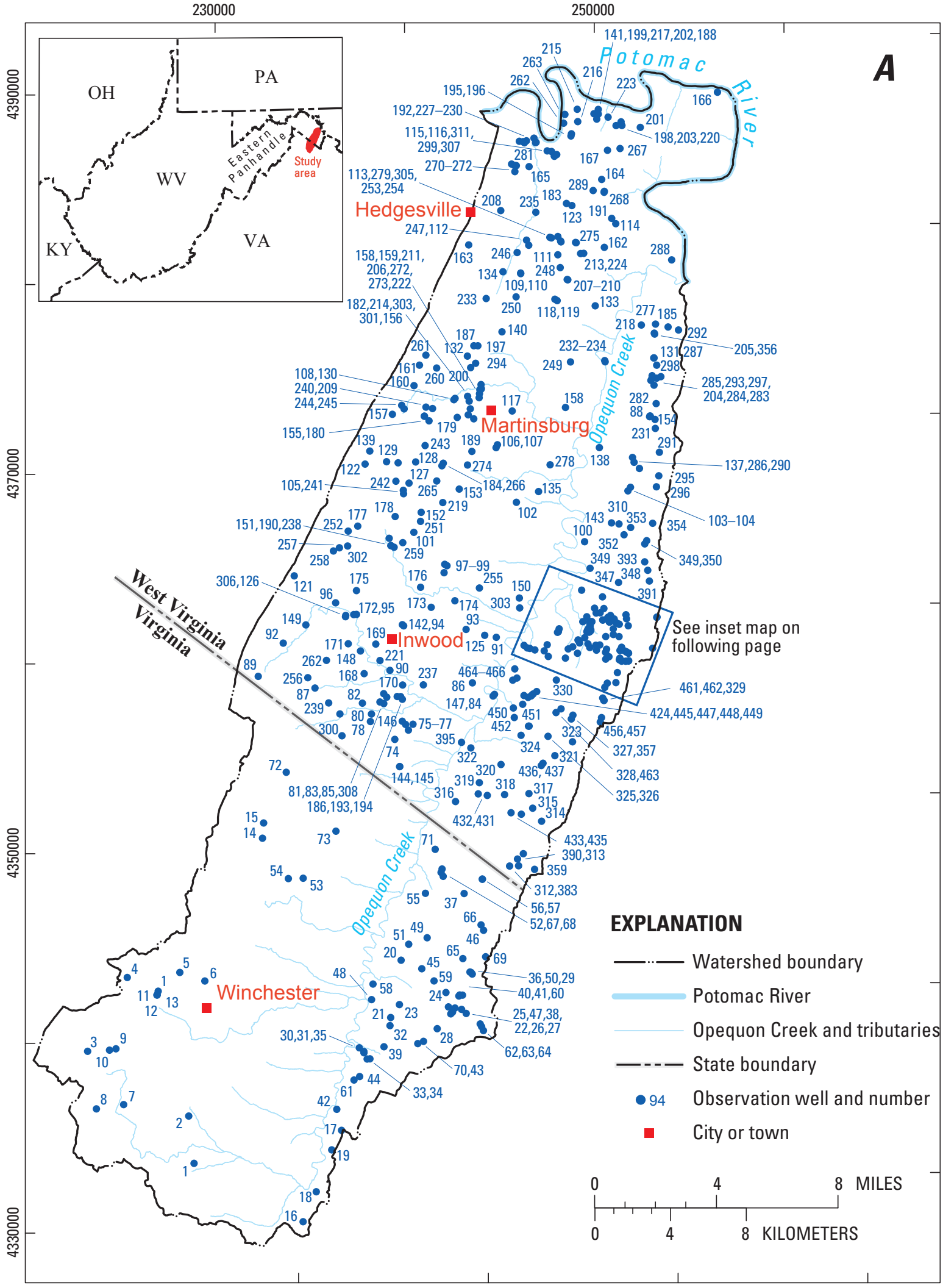

Base from U.S. Geological Survey digital data, Universal Transverse Mercator Projection, Zone 18, NAD 83.

Figure 3. Location of $(A)$ water-level observation wells used for development and calibration of the ground-water flow model of, and $(B)$ large-capacity production wells, U.S. Geological Survey streamflow-gaging stations, and wastewater-treatment-plant outfalls in, the Opequon Creek watershed area, Virginia and West Virginia. 


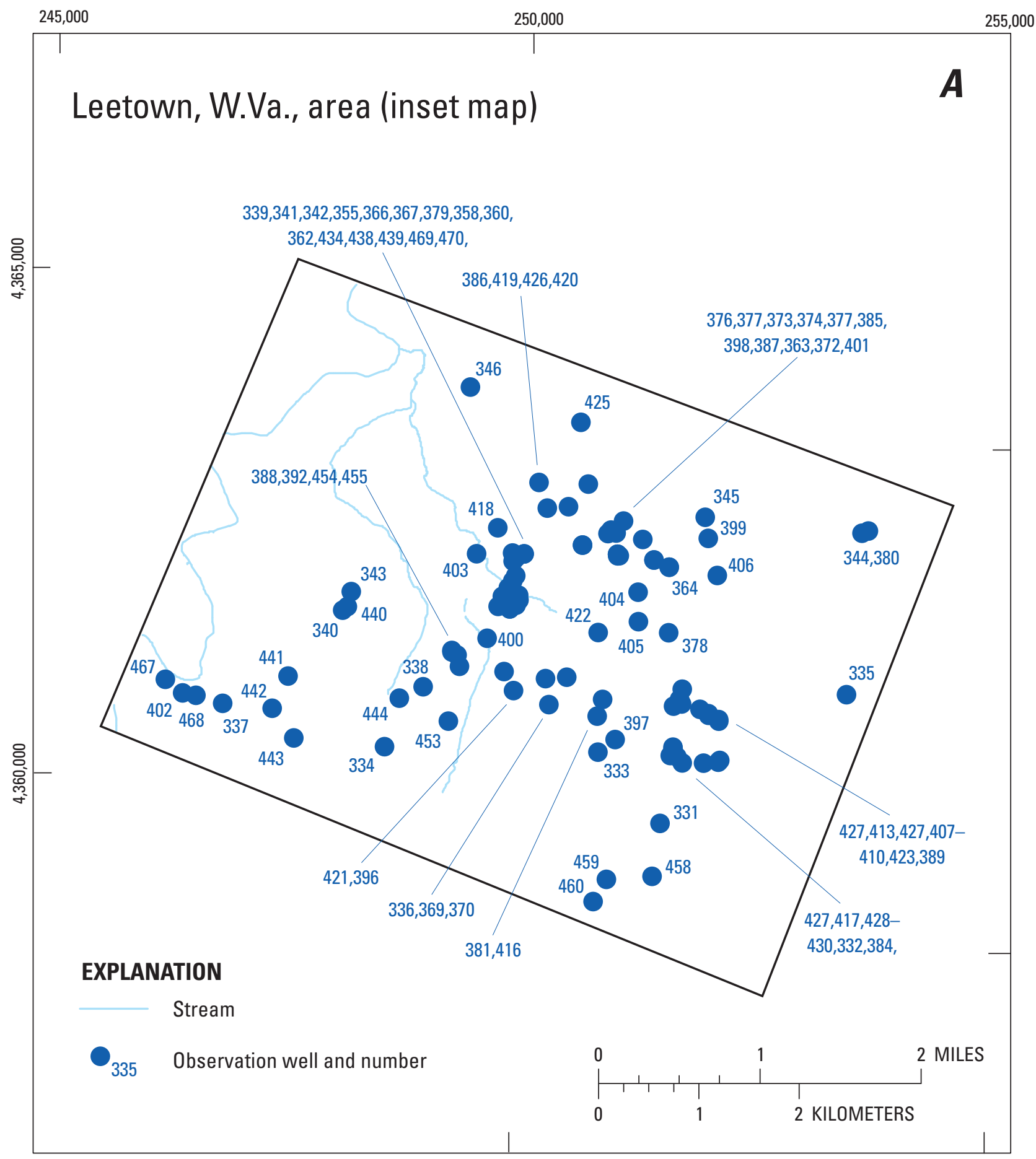

Base from U.S. Geological Survey digital data, Universal Transverse Mercator Projection, Zone 18, NAD 83.

Figure 3. Location of $(A)$ water-level observation wells used for development and calibration of the ground-water flow model of, and $(B)$ large-capacity production wells, U.S. Geological Survey streamflow-gaging stations, and wastewater-treatment-plant outfalls, in the Opequon Creek watershed area, Virginia and West Virginia._Continued 


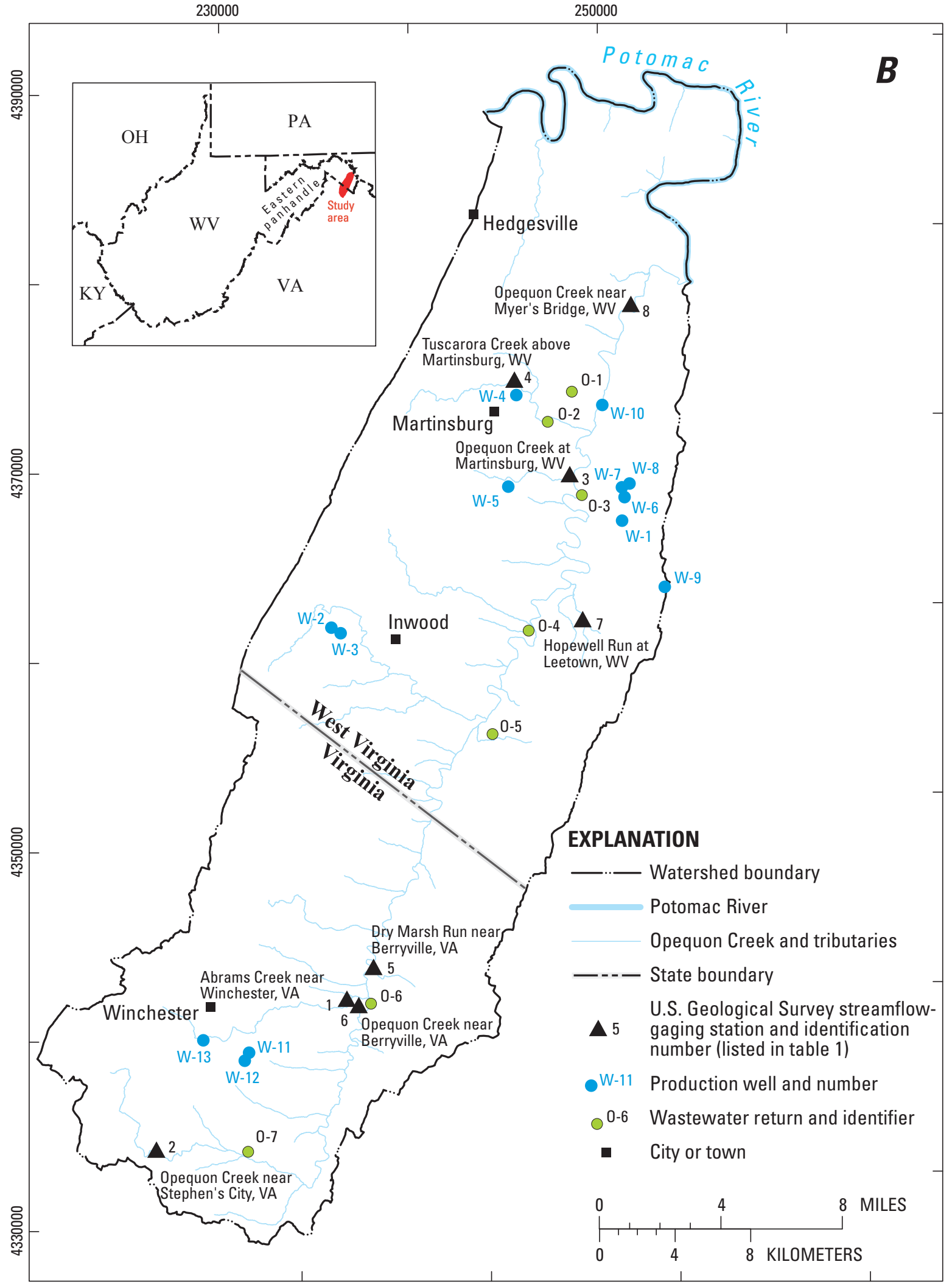

Base from U.S. Geological Survey digital data, Universal Transverse Mercator Projection, Zone 18, NAD 83.

Figure 3. Location of $(A)$ water-level observation wells used for development and calibration of the ground-water flow model of, and $(B)$ large-capacity production wells, U.S. Geological Survey streamflow-gaging stations, and wastewater-treatment-plant outfalls, in the Opequon Creek watershed area, Virginia and West Virginia.-Continued 

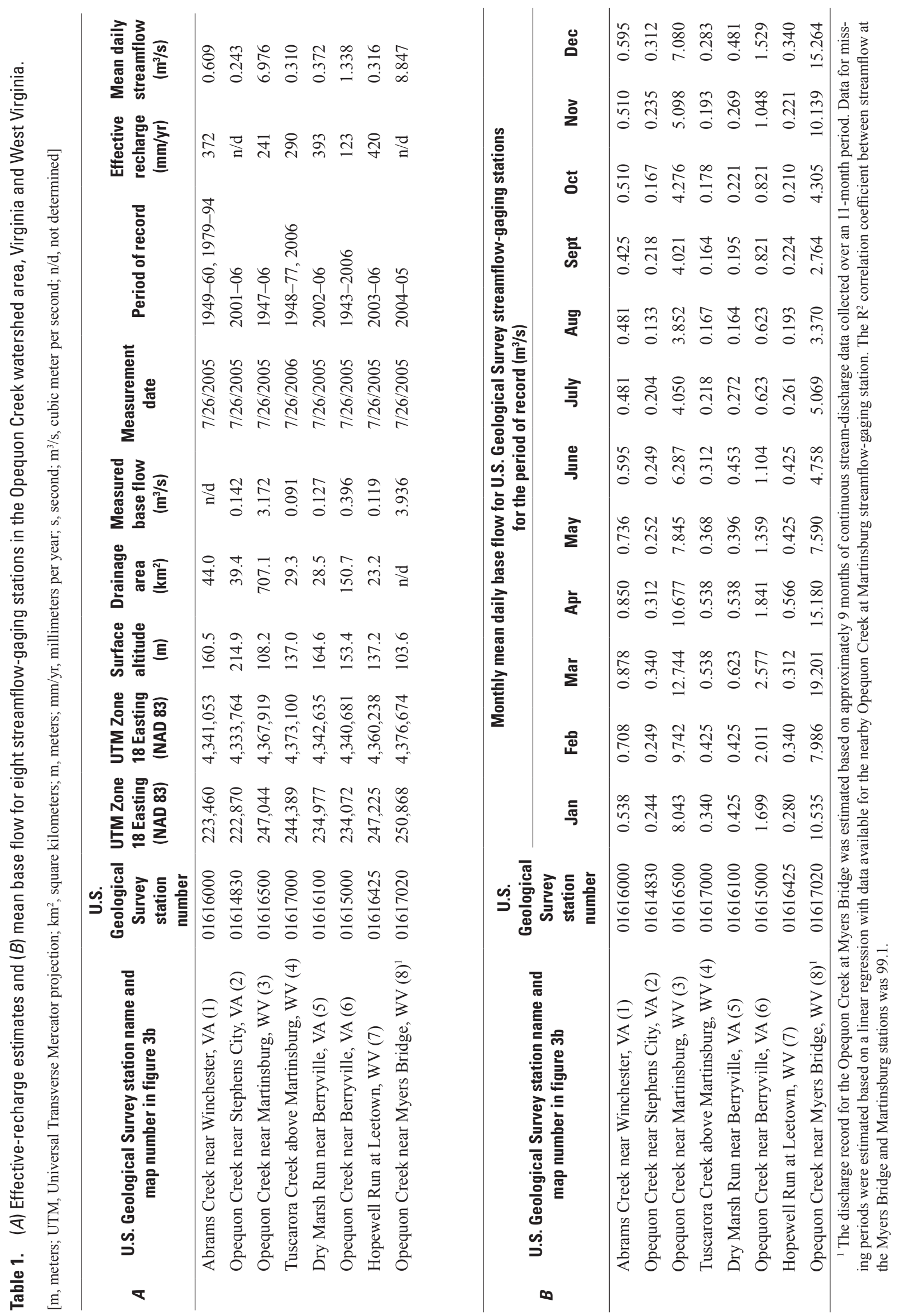


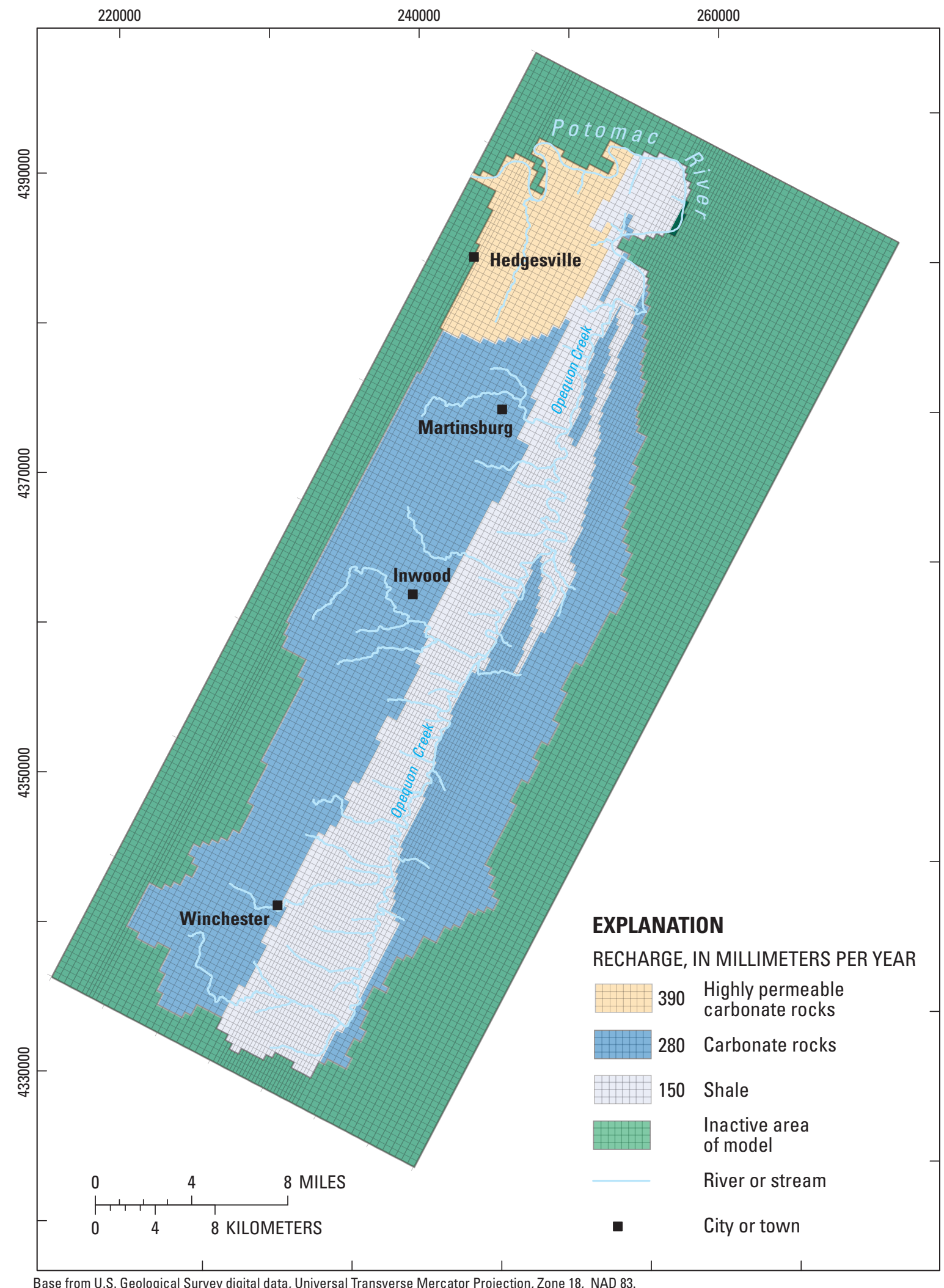

Figure 4. Model grid and recharge for the ground-water flow model of the Opequon Creek watershed area, Virginia and West Virginia. 


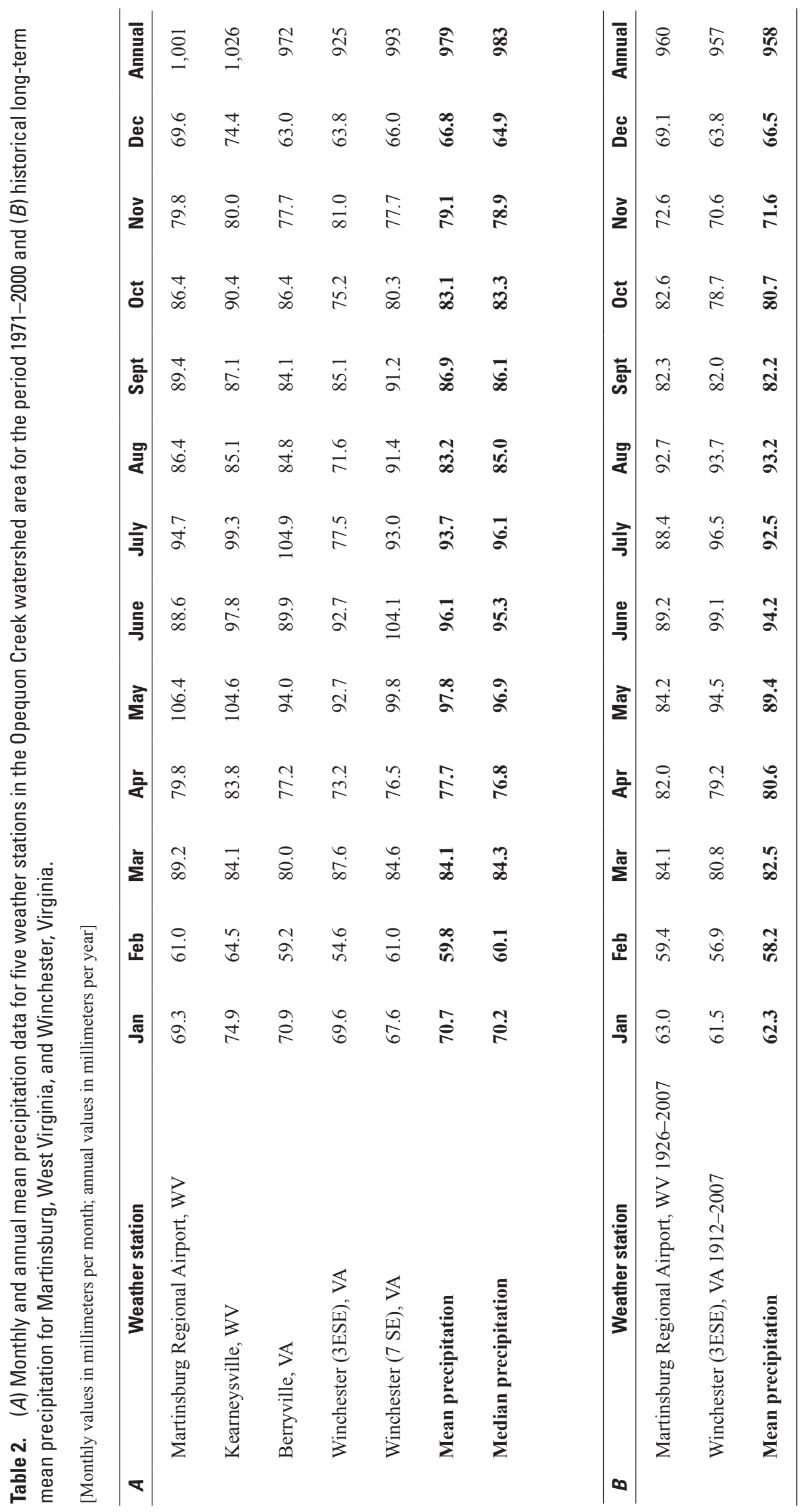


Streamflow data for the Opequon Creek near Martinsburg streamflow-gaging station for the period of record were analyzed as part of developing the ground-water flow model of the Hopewell Run watershed area (Kozar and others, 2007, 2008). The long-term average recharge for the part of the Opequon Creek watershed area draining to Opequon Creek near Martinsburg was estimated to be $250 \mathrm{~mm} / \mathrm{yr}$ (Kozar and Mathes, 2001). Meteorological records (Cornell University, 2008) indicate the most recent drought in the area occurred from November 1998 to January 2000. This was the fourth most severe drought on record, dating back to 1895 , and was the longest, lasting for approximately 16 months. Estimated ground-water recharge for the Opequon Creek near Martinsburg drainage area for the 16-month drought was $145 \mathrm{~mm} / \mathrm{yr}$ (Kozar and others, 2007, 2008), or approximately 60 percent of the average recharge rate for the watershed. Recharge for the 16-month drought was simulated by decreasing the effective recharge rates for each of the three zones used to develop the steady-state model by approximately 40 percent.

\section{Hydraulic Properties}

The hydraulic properties of aquifers that are used to develop a ground-water flow model include aquifer transmissivity, hydraulic conductivity, saturated thickness, and specific yield (storativity). Transmissivity in square meters per day $\left(\mathrm{m}^{2} / \mathrm{d}\right)$ is a measure of an aquifer's ability to transmit water and generally is defined as the rate at which water is transmitted through a unit width of aquifer under a unit hydraulic gradient (Gary and others, 1973). Saturated thickness in meters $(\mathrm{m})$ is the thickness of the aquifer that is saturated with ground water. Hydraulic conductivity in meters per day $(\mathrm{m} / \mathrm{d})$ is equal to transmissivity divided by the saturated thickness of the aquifer. Storativity is the volume of water released from storage per unit decline in head. Specific yield is a measure of the capacity of an unconfined aquifer to store water and is defined as the ratio of the volume of water a given mass of saturated aquifer will yield by gravity to the volume of that mass (Gary and others, 1973). For an unconfined aquifer, storativity is approximately equal to specific yield. These hydraulic properties were determined by conducting many single- and multi-well aquifer tests in the bedrock units of the Opequon Creek watershed area. The same units crop out at the surface over a broad area in both Jefferson and Berkeley Counties. Aquifer-test data were obtained from two previous investigations (McCoy and others, 2005a, 2005b), that include data for the Leetown area and a recent hydrogeologic investigation completed in Morgan County, West Virginia (Boughton and McCoy, 2006), and were used to determine the typical hydraulic properties of the geologic formations in the model area. Statistical analyses of these data indicate that two of the eight geologic formations that are exposed at the surface in the study area have characteristically low $(<0.8 \mathrm{~m} / \mathrm{d})$ hydraulic conductivities (table 3 ). These formations are the Martinsburg Formation and the Conococheague Limestone. Hydraulic conductivities are $0.6 \mathrm{~m} / \mathrm{d}$ for all three layers of the Martinsburg Formation and range from 0.2 to $0.8 \mathrm{~m} / \mathrm{d}$ for the Conococheague Limestone. The low hydraulic conductivity of these units (table 3) means that they control ground-water flow in the study area by acting as barriers to flow. Solution enlargement of fractures along major fault zones (simulated hydraulic conductivity ranging from 30 to $120 \mathrm{~m} / \mathrm{d}$ ) results in enhanced permeability along these features, allowing them to act as drains for water to flow easily through or across the less permeable units. The cross-strike faults and some of the oblique faults, both of which cross bedrock strike at high angles, are especially effective as conduit drains for ground water.

\section{Ground-Water Withdrawals}

The major ground-water withdrawals (fig. 3b) in the watershed are primarily from large-capacity production wells for public water supplies or for commercial or industrial activities related to quarry and aggregate operations. Large withdrawals are not common; the few large water withdrawals are tabulated in table 4 . Individual domestic withdrawals were not simulated in this model and it was assumed that most of the water withdrawn from residential wells is returned to the aquifer through septic-system return flows. Several large springs in the study area are also used as a source of water for public supply.

\section{Structural and Lithologic Controls on Ground- Water Flow}

The conceptual model of ground-water flow described above is derived primarily from the work conducted as part of the hydrogeologic assessment of the Hopewell Run watershed area near Leetown, West Virginia (Kozar and others, 2007, 2008). Although the geology of the Opequon Creek watershed area is nearly identical to that of the Hopewell Run watershed area, the structural and lithologic controls on ground-water flow in the Opequon Creek watershed area have not been fully documented. To ensure that the conceptual model developed for the Hopewell Run watershed area is applicable to the Opequon Creek watershed area, an assessment was conducted in the Opequon Creek watershed area of the locations of known springs in relation to known faults and the contacts between carbonate bedrock and the low-permeability shale bedrock of the Martinsburg Formation.

This assessment was conducted as part of a GIS analysis by plotting on a map the locations of all known springs along with the contact of the carbonate rocks with the Martinsburg Formation and the location of all known mapped faults in the region (fig. 5). A 300-m buffer zone was placed around all known faults on the GIS map, and springs were divided into three groups based on measured discharge: less than $545 \mathrm{~m}^{3} / \mathrm{d}$ (less than $100 \mathrm{gal} / \mathrm{min}$ ), 545 to $5,449 \mathrm{~m}^{3} / \mathrm{d}$ (100 to $999.9 \mathrm{gal} / \mathrm{min}$ ), and greater than $5,450 \mathrm{~m}^{3} / \mathrm{d}$ (greater 


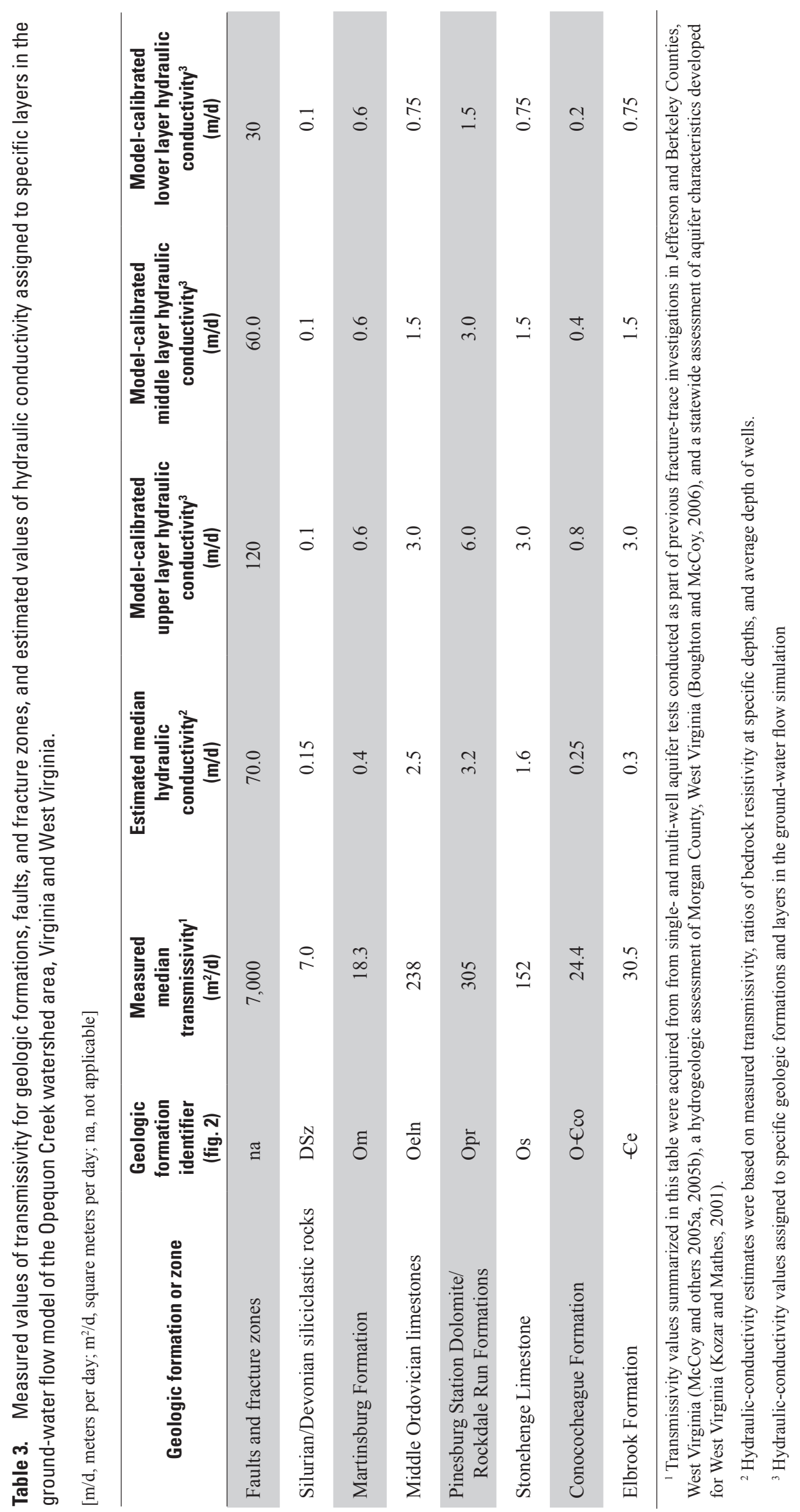


Table 4. (A) Current withdrawals from large-capacity production wells and $(B)$ return flows from wastewater-treatment plants in the Opequon Creek watershed area, Virginia and West Virginia.

[Data in this table are public records available from the West Virginia Department of Environmental Protection, West Virginia Public Service Commission, and the Virginia Department of Environmental Quality. Withdrawals and return flows are based on 2002-03 averages; m, meters; $\mathrm{m}^{3} / \mathrm{d}$, cubic meters per day; UTM, Universal Transverse Mercator Projection]

\begin{tabular}{|c|c|c|c|c|c|}
\hline$A$ & $\begin{array}{c}\text { Site } \\
\text { identification } \\
\text { number in } \\
\text { figure } 3 \mathbf{b}\end{array}$ & $\begin{array}{c}\text { UTM } \\
\text { Zone } 18 \\
\text { Northing }\end{array}$ & $\begin{array}{c}\text { UTM } \\
\text { Zone } 18 \\
\text { Easting }\end{array}$ & $\begin{array}{c}\text { Well } \\
\text { depth } \\
(\mathrm{m})\end{array}$ & $\begin{array}{c}\text { Current } \\
\text { production } \\
\left(\mathrm{m}^{3} / \mathrm{d}\right)\end{array}$ \\
\hline & W-1 & 249,476 & $4,365,335$ & 122 & 0.0 \\
\hline & W-2 & 233,821 & $4,360,756$ & 111 & 11.4 \\
\hline & W-3 & 234,245 & $4,360,525$ & 46 & 11.4 \\
\hline & W-4 & 244,391 & $4,372,420$ & 146 & 3,785 \\
\hline & W-5 & 243,327 & $4,367,733$ & 153 & 4,731 \\
\hline & W-6 & 249,810 & $4,366,842$ & 54 & 217 \\
\hline & W-7 & 249,692 & $4,366,907$ & 91 & 217 \\
\hline & W-8 & 250,018 & $4,367,360$ & 72 & 217 \\
\hline & W-9 & 251,701 & $4,361,565$ & 117 & 454 \\
\hline & W-10 & 248,718 & $4,371,569$ & 125 & 394 \\
\hline & W-11 & 227,984 & $4,338,339$ & 125 & 96 \\
\hline & W-12 & 227,882 & $4,338,189$ & 125 & 1.9 \\
\hline & W-13 & 225,605 & $4,339,071$ & 125 & 1,018 \\
\hline
\end{tabular}

\begin{tabular}{cccc}
\hline $\begin{array}{c}\text { Site } \\
\boldsymbol{B} \\
\begin{array}{c}\text { identification } \\
\text { number in } \\
\text { figure 3b }\end{array}\end{array}$ & $\begin{array}{c}\text { UTM } \\
\text { Zone 18 } \\
\text { Northing }\end{array}$ & $\begin{array}{c}\text { UTM } \\
\text { Zone 18 } \\
\text { Easting }\end{array}$ & $\begin{array}{c}\text { Return } \\
\text { flow } \\
\left(\mathbf{m}^{3} / \mathbf{d}\right)\end{array}$ \\
\hline O-1 & 247,414 & $4,372,681$ & 118.8 \\
\hline O-2 & 245,829 & $4,371,035$ & 417.1 \\
\hline O-3 & 247,544 & $4,367,120$ & 89.7 \\
\hline O-4 & 244,250 & $4,360,159$ & 69.6 \\
\hline O-5 & 241,890 & $4,354,742$ & 61.7 \\
\hline O-6 & 234,392 & $4,340,886$ & 1012.9 \\
\hline O-7 & 227,309 & $4,333,443$ & 207.4 \\
\hline
\end{tabular}

than $1,000 \mathrm{gal} / \mathrm{min}$ ). The locations of the springs then were assessed in relation to discharge and proximity to known faults or the contact between carbonate bedrock and the shale bedrock of the Martinsburg Formation (table 5). Faults and the Martinsburg Formation were found to be strong controls on ground-water flow in the Hopewell Run watershed area. The locations of springs were found to correlate with distance to known major faults and the contact with the Martinsburg Formation (table 5). Mean spring discharge and location information for the known springs in the Opequon Creek watershed area are presented in appendix 2 . Sixty-one percent of all known springs and 80 percent of large springs with flow in excess of $1,000 \mathrm{gal} / \mathrm{min}$ were found within $300 \mathrm{~m}$ of either a known fault or the contact with the Martinsburg Formation.

\section{Simulation of Ground-Water Flow}

A calibrated steady-state ground-water flow model was developed and analyzed to (1) develop a water budget for the study area and assess the effects of ground-water withdrawals on long-term water availability, (2) evaluate hydraulic heads simulated by the model to better understand groundwater flow in the watershed and to assess potential structural controls on ground-water flow, (3) assess effects of drought on water availability by reducing the recharge to the model and comparing simulated water levels for average hydrologic periods to those simulated for drought periods, and (4) assess ground-water yields for subwatersheds in the model to evaluate potential availability of ground water during average and drought conditions in various parts of the watershed.

The suitability of using a three-dimensional numerical model such as MODFLOW for simulating ground-water flow in a karst setting is subject to debate. Because an equivalent porous medium is assumed in MODFLOW, its use in simulating ground-water flow may be inappropriate for some karst aquifers. This is especially true for cavernous and largeconduit-dominated karst systems such as that found in the Mammoth Cave area of Kentucky. MODFLOW has been effectively used to simulate ground-water flow in many karst aquifer systems, however. Although the aquifer does exhibit some karst features, sinkhole development is sparse, and caverns, where encountered, are limited in length and width. The majority of the rock mass in the region, especially in upland areas, is drained by an interconnected network of bedrock fractures with little solution development. The conduits that develop, predominantly in low-lying areas, act as drains for the interconnected fracture network in the more areally extensive fractured-rock mass. In the model, the conduits were simulated as a network of interconnected drains by assigning higher hydraulic conductivities to these more permeable features and the fractured-rock portion of the aquifer was effectively simulated by using an equivalent-porous-medium approach. Models that do not account for conduit drains or aquifer anisotropy do not effectively simulate ground-water flow in fracture-dominated karst aquifers drained by solution conduits. 


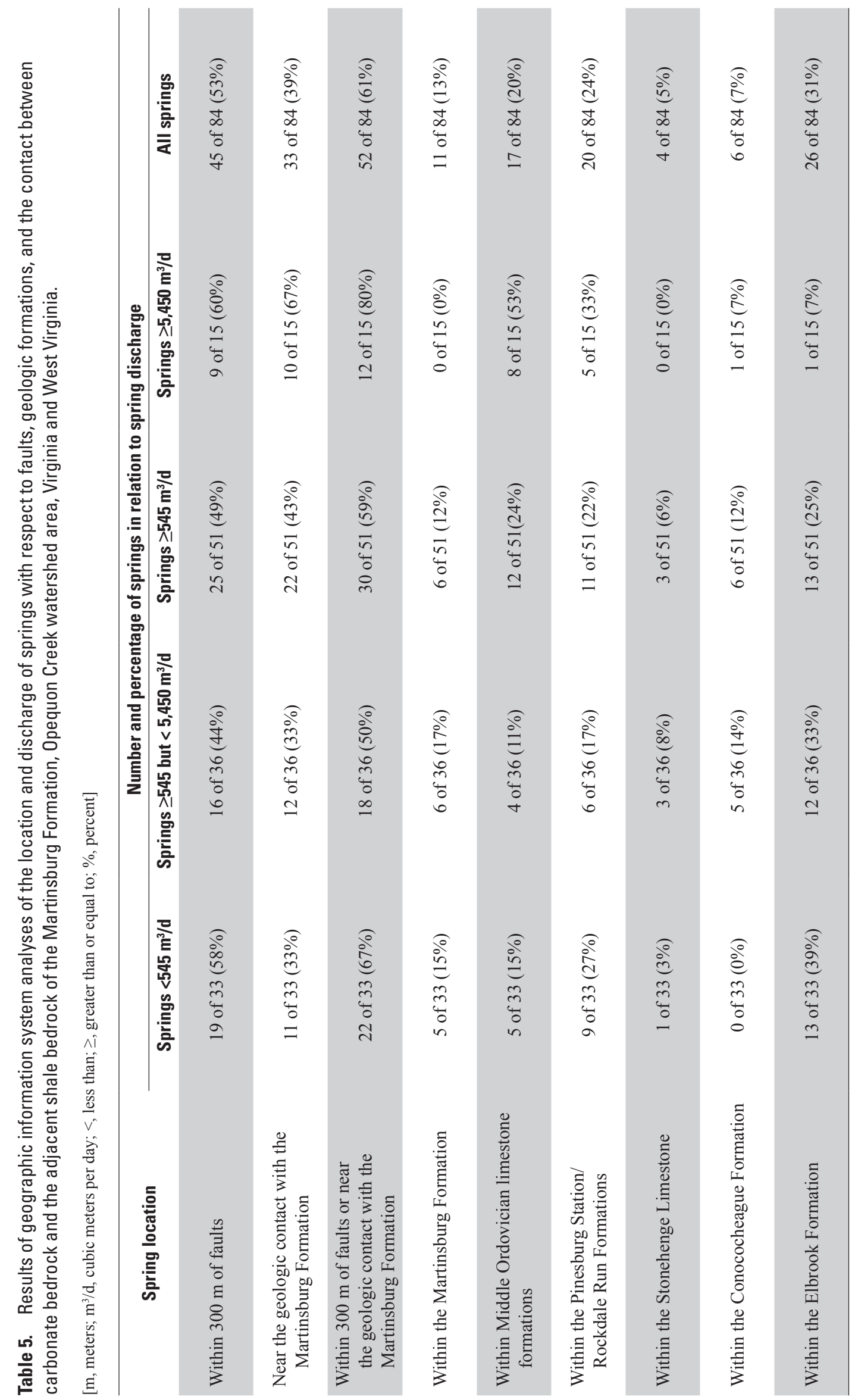




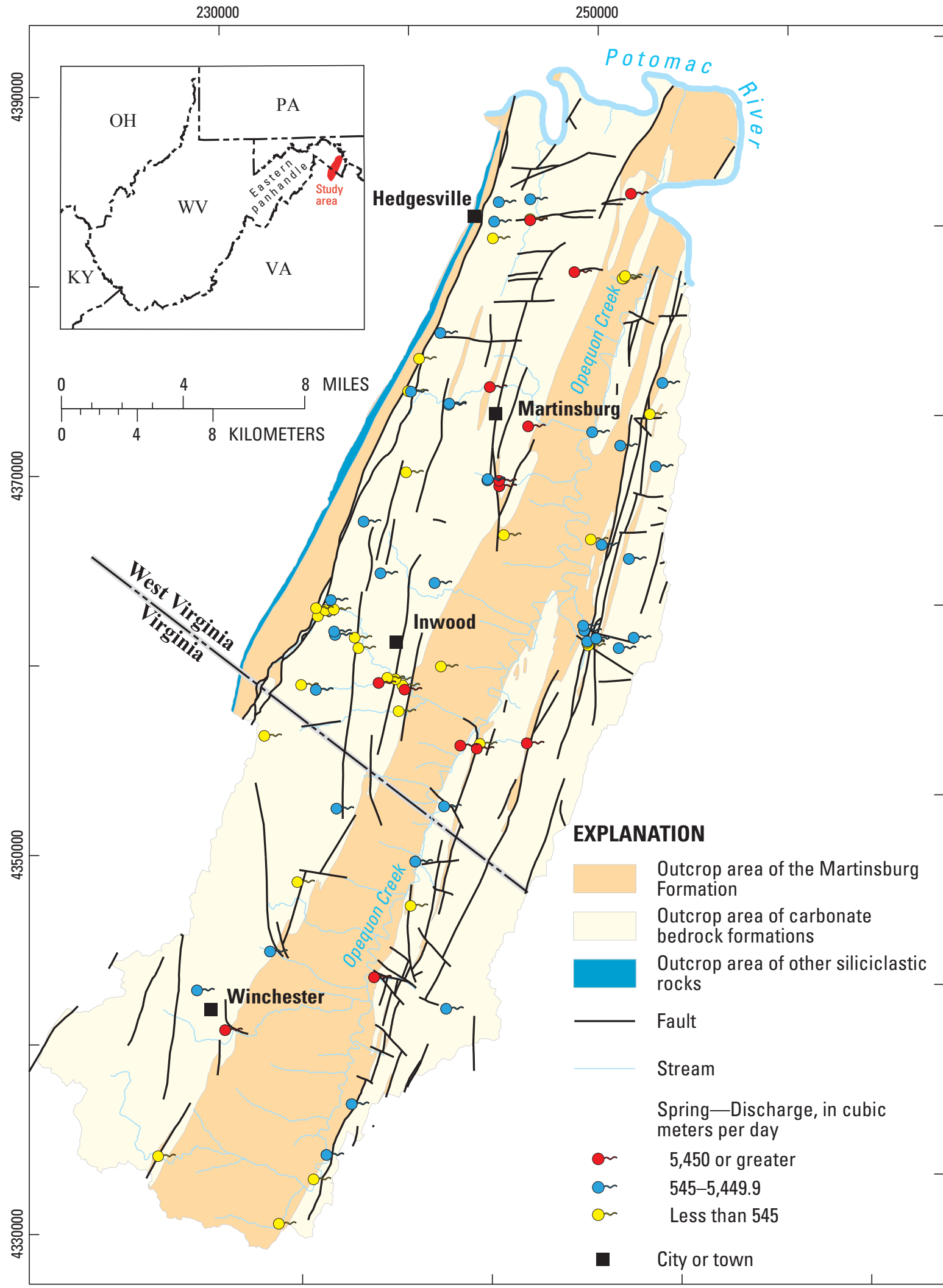

Base from U.S. Geological Survey digital data, Universal Transverse Mercator Projection, Zone 18, NAD 83.

Figure 5. Distribution of disharge from selected springs and location of known faults and the contact between the Martinsburg Formation and other carbonate bedrock units in the Opequon Creek watershed area, Virginia and West Virginia. 
Previous simulations of ground-water flow have been effectively developed in karst hydrogeologic settings similar to that of the Hopewell Run and Opequon Creek watershed areas using an equivalent-porous-medium approach and the MODFLOW software. White (2002) discussed the problems of simulating ground-water flow in karst settings but also indicated that the equivalent-porous-medium approach can work well when the locations of the major conduit drains are known or can be accurately estimated. A few examples of other equivalent-porous-media modeling of karst systems using MODFLOW include models developed for the Madison aquifer in South Dakota (Putnam and Long, 2005), the Edwards aquifer in Texas (Lindgren and others, 2005), the Burlington-Keokuk Limestone aquifer in Missouri (Quinn and others, 2005a), the Malm Formation aquifer in Germany (Quinn and others, 2005b), and the Boone-St. Joe Limestone aquifer in Arkansas (Unger and others, 2003).

The methods described were tested and evaluated in a steady-state ground-water flow model developed for the Hopewell Run watershed area in Jefferson County, West Virginia, and were found to work well for simulating groundwater flow in the complex, fracture-dominated karst aquifer in that area (Kozar and others, 2007, 2008). Geologic mapping, surface-geophysical surveys, and analysis of Light Detection and Ranging (LiDAR) imagery were employed in a hydrogeologic assessment of the Hopewell Run watershed area (Kozar and others, 2007, 2008) to accurately map the location of conduit drains within the aquifer. Hopewell Run is a tributary to the Opequon Creek, the hydrogeologic settings of the two watersheds are similar, and both watersheds are composed of the same bedrock formations. Because it was not practical to collect as intensive a data set of aquifer properties, water levels, and surface-geophysical and fracture-occurrence data for the Opequon Creek watershed area as was collected and analyzed for the Hopewell Run watershed area, the conceptual model of ground-water flow developed for the smaller Hopewell Run watershed area was extrapolated to the larger Opequon Creek watershed area.

\section{Conceptual Model of Ground-Water Flow}

A previously developed conceptual model of groundwater flow (Kozar and others, 1991; Shultz and others, 1995) in the Jefferson and Berkeley County areas of West Virginia was modified on the basis of additional borehole- and surfacegeophysical data and geologic mapping conducted as part of an intensive investigation of the hydrogeology and groundwater flow in the Hopewell Run watershed area, West Virginia (Kozar and others, 2007, 2008). As Hopewell Run is part of the Opequon Creek watershed area and the geology and hydrology of the areas are similar, the conceptual model of ground-water flow developed for the Hopewell Run watershed area was applied to the larger Opequon Creek watershed area. Major findings of the studies were that although recharge to sinkholes can occur, it is not a dominant process, and groundwater recharge is distributed over a broad area. Recharge to sinkholes can be a dominant process only when surface runoff occurs, typically as a result of intense rainfall, and for sinkholes with large drainage areas. Areal recharge occurs as precipitation falls on the surface, quickly infiltrates the soil and regolith, and percolates into the epikarst, a zone of intense weathering from land surface to a depth of approximately 20 $\mathrm{m}$. Hydrogeologic settings of carbonate bedrock bounded by low-permeability bedrock such as the Conococheague Limestone and Martinsburg Formation are conducive to conduit development and may provide good locations for development of ground-water supplies. Large quantities of ground water are funneled through these areas, but water availability is limited by periods of low streamflow and low ground-water levels. In addition to the Hopewell Run watershed area, there are other areas where low-permeability bedrock forces ground water to flow along strike-parallel thrust faults, resulting in large springs; these include areas near Inwood (Bunker Hill), Middleway, Winchester, and Martinsburg, along the margins of the Martinsburg Formation.

The epikarst is characterized by solutionally enlarged bedding planes and high-angle joints that allow rapid infiltration of water to the deeper bedrock aquifer. Below the epikarst, an intermediate zone of less weathered bedrock is present. This intermediate zone of moderately fractured bedrock typically does not exhibit the high density of solutionally enlarged conduits that is evident in the epikarst. Hydraulic conductivity is less in the intermediate zone than in the epikarst. Below a depth of about $75 \mathrm{~m}$, the aperture of bedrock fractures decreases substantially, and the estimated hydraulic conductivity, based on aquifer-test data, is approximately half that in the intermediate zone. Vertical hydraulic conductivity is poorly understood and was simulated in both the Hopewell Run and Opequon Creek models as approximately one-tenth of the horizontal hydraulic conductivity. Sensitivity tests were used to evaluate the importance of variations in vertical hydraulic conductivity in the model.

The ground-water flow system is a triple-porosity system with negligible intergranular primary porosity. Microfractures (matrix porosity) provide some storage of water, a dominant set of diffuse fractures provides most of the storage in the aquifer, and a system of solutionally enlarged fractures (conduits) acts as drains for the intricate network of secondary-porosity features. Flow of ground water in the epikarst can be rapid, on the order of weeks, as indicated by results of tracer tests conducted in the area (Jones, 1997; Jones and Deike, 1981). This is especially true if flow is concentrated in solutionally enlarged conduits. Ground water in the intermediate zone is much older; estimates of ground-water age in the Great Valley carbonate rocks are on the order of 15 to 50 years (McCoy and Kozar, 2007a). There are few data from which to estimate the age of ground water in the deeper parts of the aquifer. It is likely that ground water flows slowly at depths greater than about $100 \mathrm{~m}$. A chlorofluorocarbon (CFC) analysis of water from a 145-m-deep well at the USGS Leetown Science Center in the Hopewell Run watershed area indicated an apparent ground-water age of approximately 50 years. Water from greater depths is likely much older (Kozar and others, 2008). 
Topography also has a major effect on ground-water flow. Depth to water typically is greater on hilltops than in valley or hillside settings. Upland areas are commonly formed from more resistant rock. These rock units typically have lower hydraulic conductivities than the more permeable formations in lowland areas. The Conococheague Limestone and Elbrook and Martinsburg Formations (fig. 2) are the principal lower permeability units and act as barriers to downgradient flow of ground water. Regional ground-water flow in the study area is primarily from the topographically higher areas in the east and west toward Opequon Creek, which drains the watershed near the center of the north-northeast-trending valley. The low-permeability Martinsburg Formation and Conococheague Limestone provide dominant controls on ground-water flow, impeding flow toward Opequon Creek. Water is forced to flow parallel to bedrock strike along solutionally enlarged thrust faults. Cross-strike faults, oblique faults, and associated fracture zones provide avenues along which ground water can flow either across or through the less permeable units.

The ground-water flow model developed for this investigation is a steady-state model of the Opequon Creek watershed area, including areas that drain directly to the Potomac River in the northern part of the study area (fig. 1). A 30-m USGS digital elevation model (DEM) of the Opequon Creek watershed area (fig. 6) provided the elevation from which the upper surface of the ground-water flow model was derived. Elevations in the watershed are highest in the southwestern part of the study area and along North Mountain in the west; the lowest are in the northern part of the watershed along the Potomac River. Topography, structural features such as thrust faults and cross-strike faults, and low-permeability bedrock such as the Conococheague Limestone and Elbrook and Martinsburg Formations are the principal factors governing rates and directions of ground-water flow in the watershed.

\section{Design and Assumptions}

The ground-water flow model is based on the conceptual model of ground-water flow previously discussed and derived primarily from investigations conducted for the Hopewell Run watershed area near Leetown, West Virginia (Kozar and others, 2007, 2008) The model consists of three layers that are used to simulate (1) the epikarst zone; (2) the primary intermediate zone in which most wells are completed; and (3) the less fractured, deeper part of the bedrock aquifer (fig. 7).

Assumptions were made for areas where data were limited or unavailable and for the overall depth of ground-water flow simulated by the model. Geologic maps developed as part of this investigation provided the locations of the major thrust and cross-strike faults, which were the basis for the simulation of conduits in the model. Aquifer tests conducted in the region (McCoy and others, 2005a, 2005 b) indicate that the faults in the area tend to have higher hydraulic conductivity than the bedrock formations (table 3). Therefore, as in the groundwater flow model for the Hopewell Run watershed area (Kozar and others, 2007, 2008), faults were simulated as areas of high conductivity throughout the model. Because few data were available to characterize the peripheral areas of the model, especially along the North Mountain fault, some simplifying assumptions were made. The simulation along North Mountain is less accurate than in other areas of the model; however, this area is not an emphasis of the study.

The base elevation of the study area near the Potomac River is approximately $130 \mathrm{~m}$. Because the Potomac River is the primary surface- and ground-water discharge zone in the region, it is assumed that substantial ground-water flow does not occur at depths much greater than the base level of the Potomac River. However, the ground-water flow model was extended to a depth of approximately $30 \mathrm{~m}$ below NAVD 88 to account for the small amount of deeper ground-water flow that may occur. The maximum depth of ground-water flow simulated was approximately $185 \mathrm{~m}$ below land surface. Landsurface elevations simulated in the model range from a maximum of $390 \mathrm{~m}$ above NAVD 88 in the southwestern part of the model and along North Mountain to $130 \mathrm{~m}$ above NAVD 88 along the Potomac River in the northeastern part.

\section{Grid, Layers, and Boundary Conditions}

The model grid (fig. 4) extends from the Potomac River in the north to Winchester, Virginia, to the south, and is bounded by North Mountain to the west and by bedrock ridges to the east. The variably spaced grid consists of 170 rows and 73 columns, includes 37,230 individual nodes, and encompasses an area of $1,010 \mathrm{~km}^{2}$. The larger nodes in the model each represent a surface area of approximately $472 \mathrm{~m}$ by $409 \mathrm{~m}$ and the smaller nodes each represent a surface area of approximately $236 \mathrm{~m}$ by $409 \mathrm{~m}$. Approximately one-third of the nodes in the model are inactive. Opequon Creek and the Potomac River are the major streams simulated in the model.

The model consists of three layers that represent the layers previously discussed in "Conceptual Model of GroundWater Flow." Hydraulic conductivity is greatest in the upper layer (fig. 8 and table 3), which represents the epikarst and extends from land surface to a depth of $35 \mathrm{~m}$. The middle layer represents the fracture-dominated bedrock part of the aquifer in which most wells are completed (fig. 9); it is $65 \mathrm{~m}$ thick and was assigned hydraulic conductivities approximately 2.0 to 2.5 times lower than those assigned to layer 1 . The lower layer (fig. 10) represents mostly fractured rock with low permeability and little or no conduit development. This layer represents approximately $85 \mathrm{~m}$ of bedrock, and was assigned hydraulic conductivities approximately half that of the middle layer. The lower layer of the model extends to near or below NAVD 88 in most areas.

Two different boundary conditions were simulated in the model (fig. 11). No-flow cells were assigned to the bedrock ridges on the eastern, western, and southern margins of the model. The Opequon Creek and its tributaries were simulated with stream cells (fig. 11). Use of stream cells provided a more realistic simulation of spring and streamflow than was possible with either the river or the drain packages within 


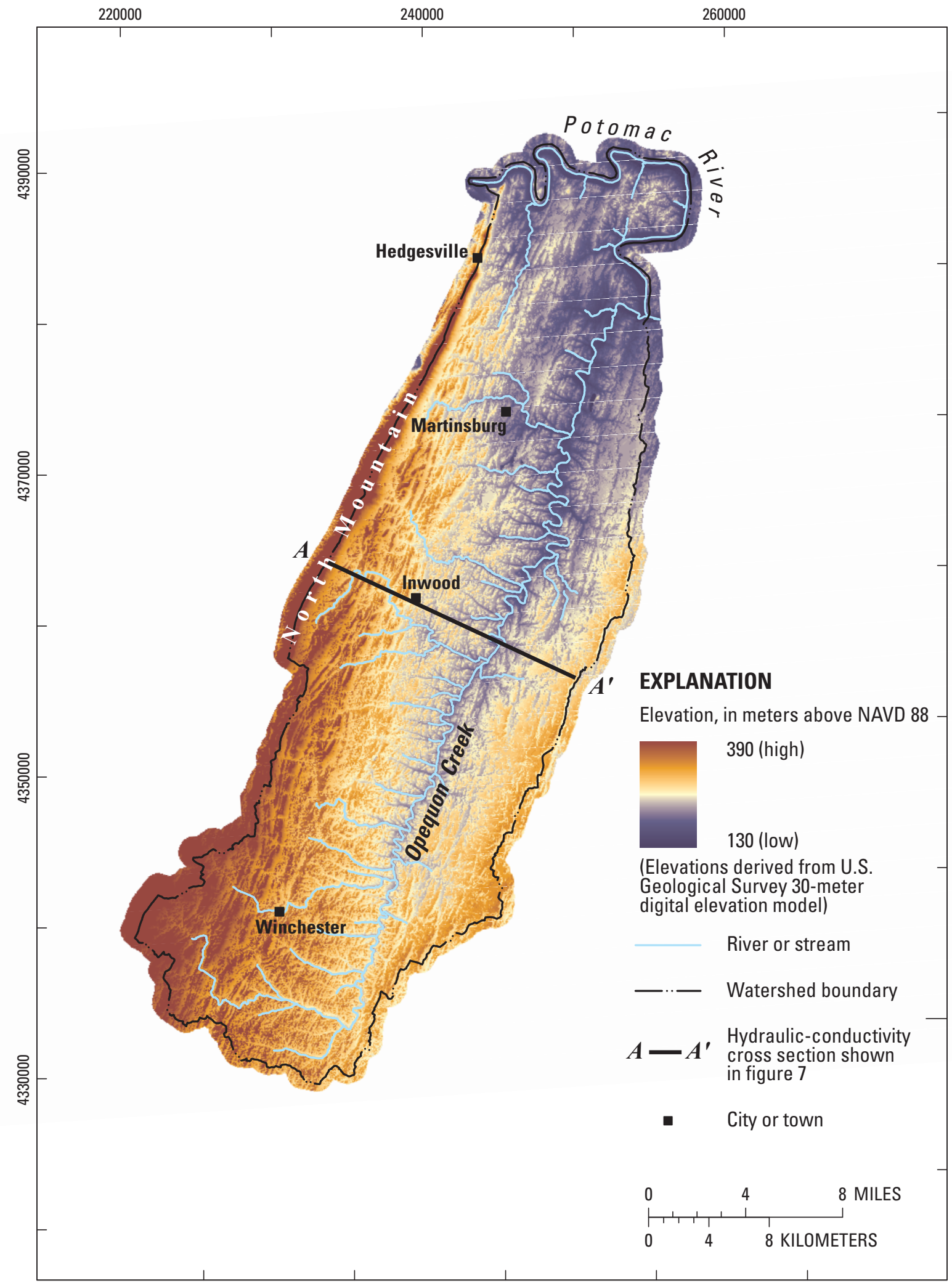

Base from U.S. Geological Survey digital data, Universal Transverse Mercator Projection, Zone 18, NAD 83.

Figure 6. Digital elevation map of the Opequon Creek watershed area, Virginia and West Virginia. 
EXPLANATION

Hydraulic conductivity, in meters per day
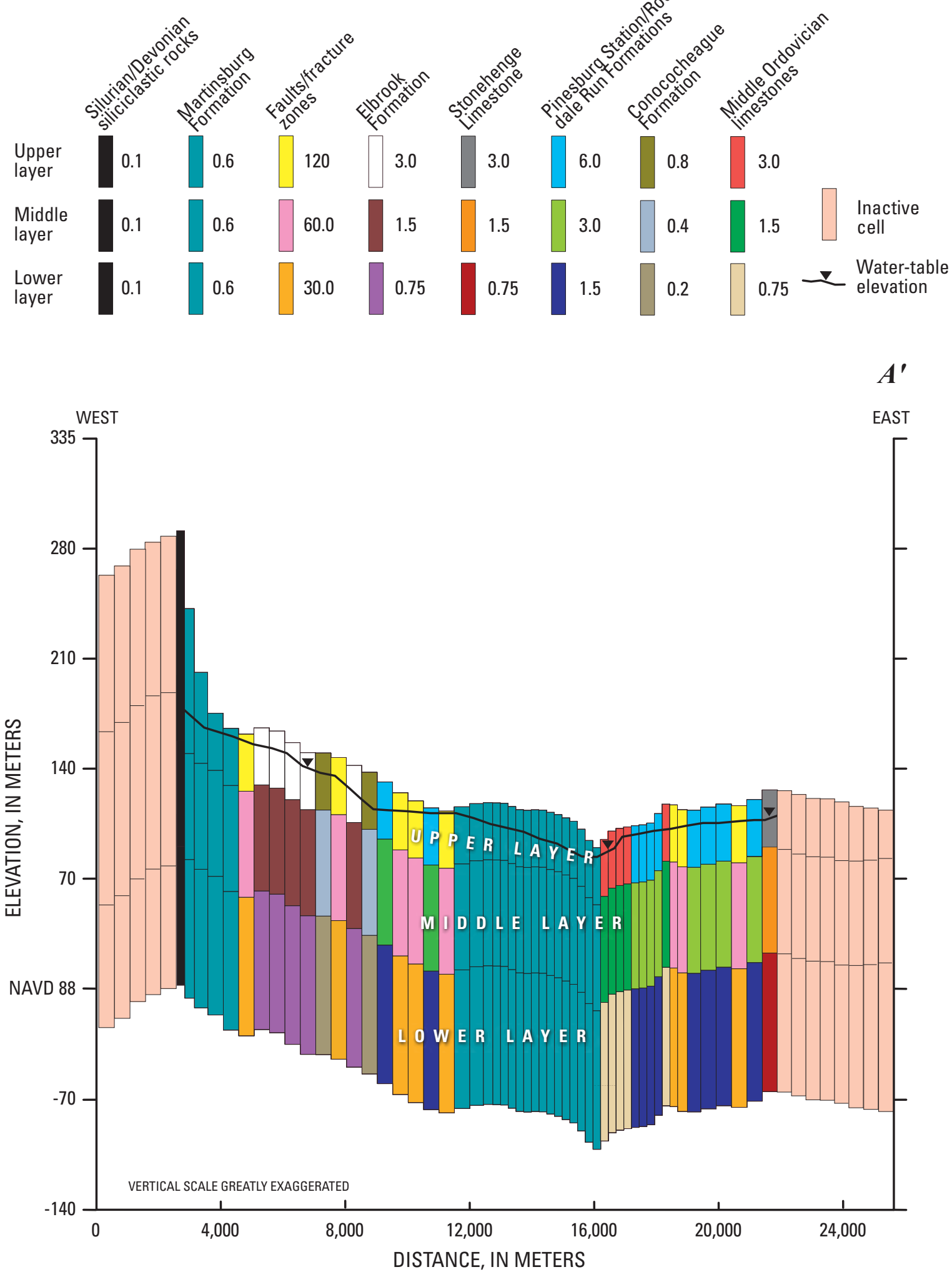

Figure 7. Cross section (as shown in figure 6) of the model-layer configuration, hydraulic conductivity, inactive cells, and water-table elevation simulated in the ground-water flow model of the Opequon Creek watershed area, Virginia and West Virginia. 


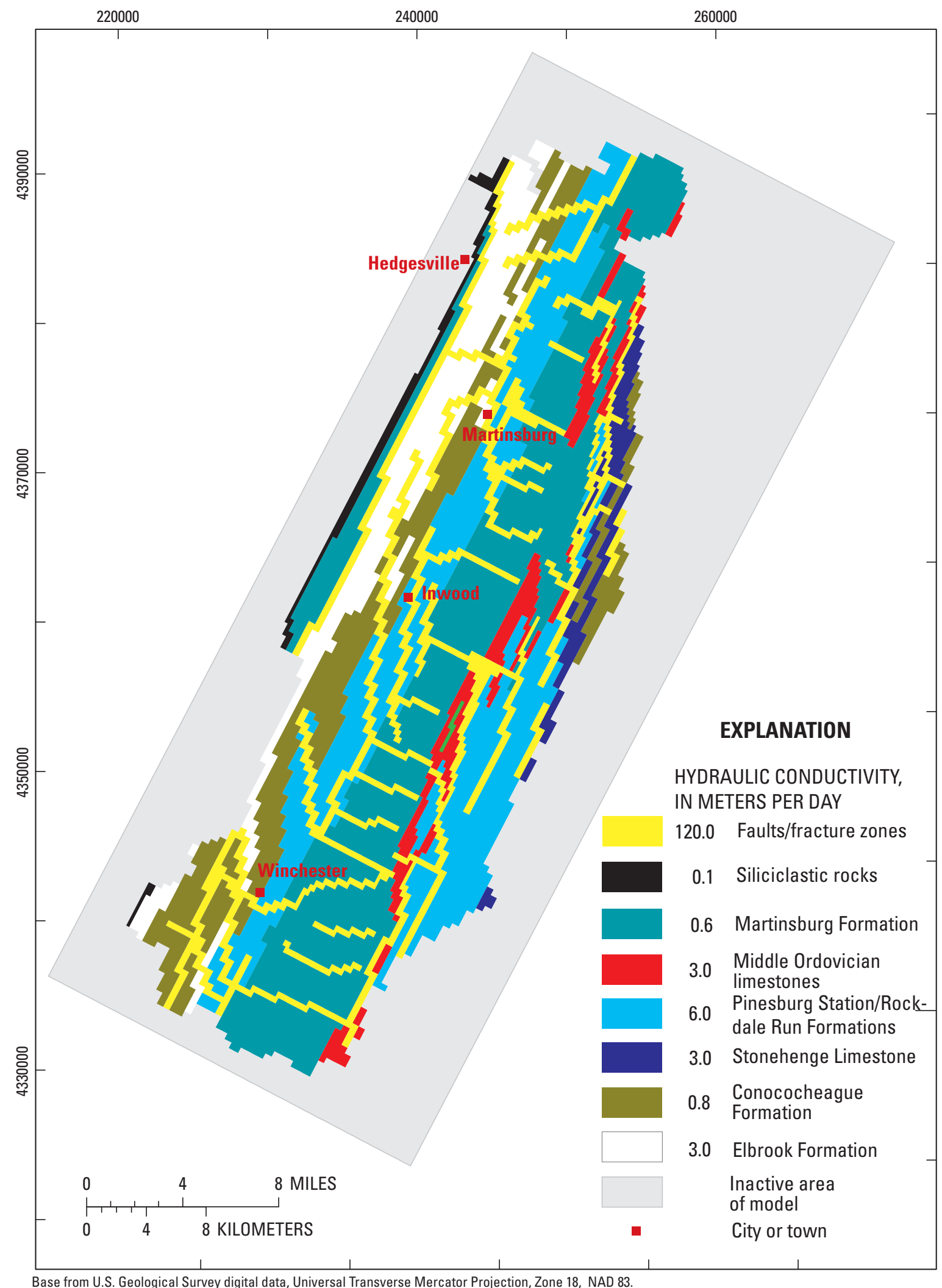

Figure 8. Hydraulic conductivities assigned to the upper layer of the ground-water flow model of the Opequon Creek watershed area, Virginia and West Virginia. 


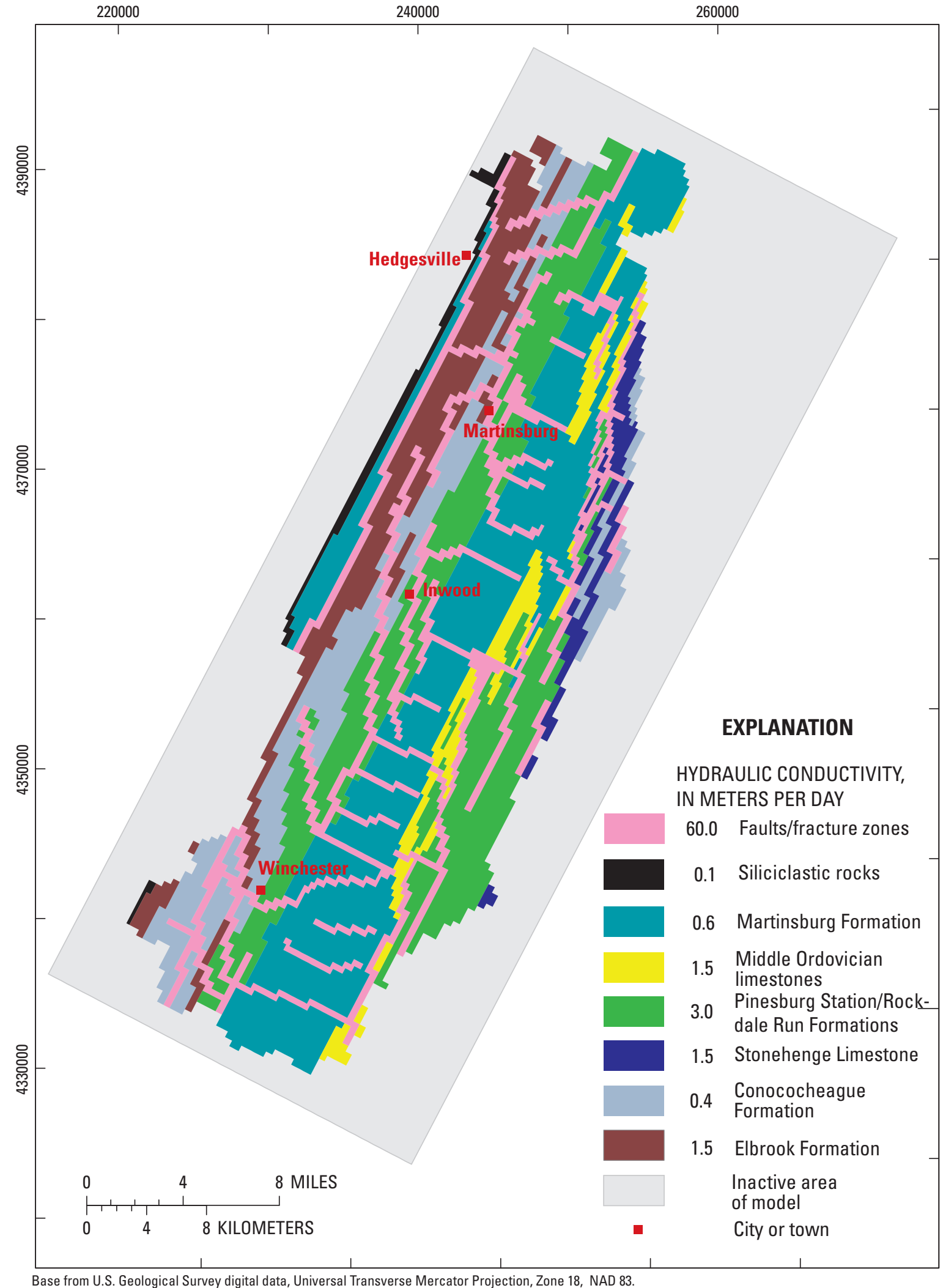

Figure 9. Hydraulic conductivities assigned to the middle layer of the ground-water flow model of the Opequon Creek watershed area, Virginia and West Virginia. 


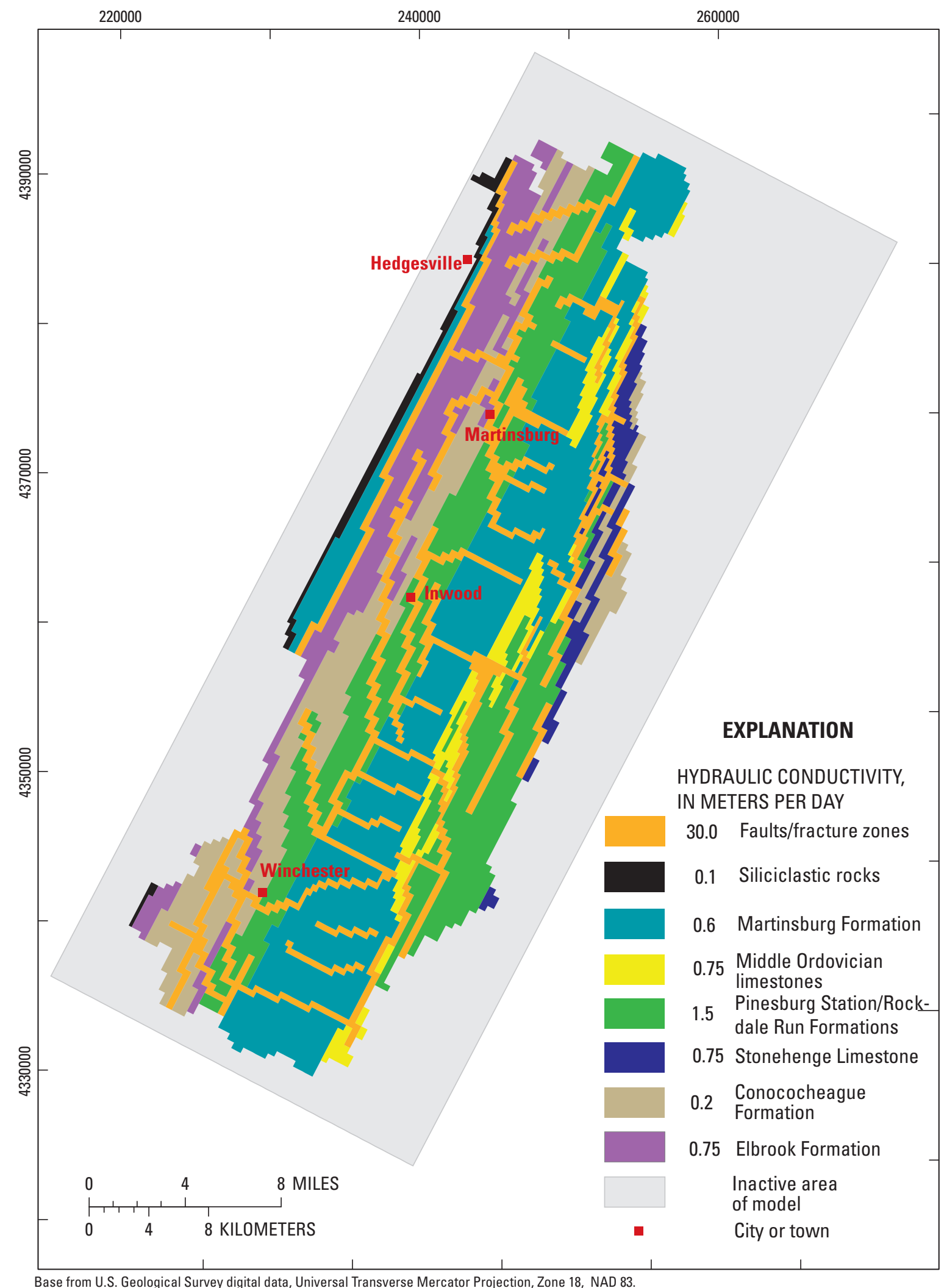

Figure 10. Hydraulic conductivities assigned to the lower layer of the ground-water flow model of the Opequon Creek watershed area, Virginia and West Virginia. 


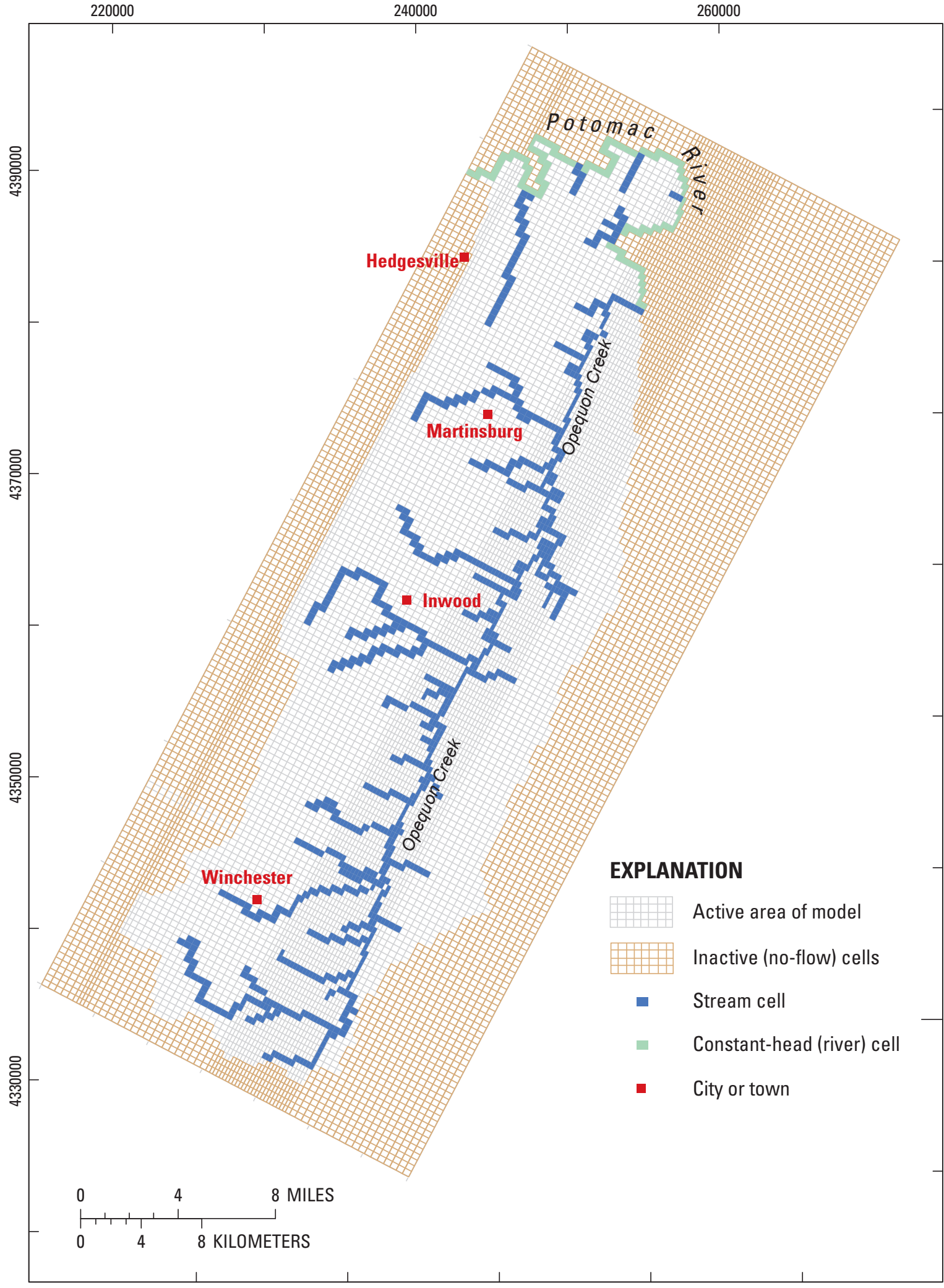

Base from U.S. Geological Survey digital data, Universal Transverse Mercator Projection, Zone 18, NAD 83.

Figure 11. Boundary conditions and the active and inactive cells of the ground-water flow model of the Opequon Creek watershed area, Virginia and West Virginia. 
Visual MODFLOW. A streambed conductance of $0.09 \mathrm{~m} / \mathrm{d}$ and a streambed thickness of $2 \mathrm{~m}$ were applied to all stream cells in the model. There is likely substantial variability in both streambed conductance and streambed thickness across the Opequon Creek watershed area, but site-specific data were not available to assess the range in variability. The Potomac River was simulated as constant-head cells using the MODFLOW river package, as river and ground-water levels on the Potomac River are regulated by locks and dams along its length and are relatively constant during base flow. Stream stage for the Potomac River, Opequon Creek, and tributaries were estimated from DEM elevation data and measurements of streamflow available from base-flow surveys conducted in the watershed (Evaldi and Paybins, 2006a, 2006b)

\section{Calibration}

The ground-water flow model was calibrated to both stream base flow and hydraulic heads (ground-water levels). USGS streamflow-gaging stations in the watershed (fig. $3 \mathrm{~b}$ and table 1) provided the base-flow data to which simulated flows of Opequon Creek were calibrated. Water levels measured in 470 wells provided the data for calibration of the hydraulic heads simulated with the ground-water flow model. Aquifer-test results available for more than 300 wells provided the data needed for assigning hydraulic conductivity in the model. Because such an abundant data set of base-flow, waterlevel, and aquifer hydraulic data were available for development and calibration of the model, parameter estimation was not conducted. The model was calibrated manually by varying input parameters through a reasonable range of values until model output reasonably replicated observed base-flow and water-level data.

The Zonebudget subroutine in Visual MODFLOW was used to calculate the water budgets for 34 subwatersheds in the model (fig. 12). Base-flow discharge simulated in the model was compared to long-term measured base flow for two streamflow-gaging stations, one in the headwaters of the basin near Berryville, Virginia, and another upstream from the mouth of Opequon Creek near Martinsburg, West Virginia. The comparisons were made to assess the predictive capability of the model in simulating flow. A well-calibrated model provides the flux of water into and out of the aquifer and provides a baseline for managing water availability within the watershed. Results of the Zonebudget analyses are presented for simulated average and drought hydrologic conditions (tables 6a, 6b).

Simulated stream base flow in the model for the streamgaging station on the Opequon Creek near Martinsburg was $5.01 \mathrm{~m}^{3} / \mathrm{s}$. The long-term median and mean streamflow recorded for this station are $4.05 \mathrm{~m}^{3} / \mathrm{s}$ and $6.95 \mathrm{~m}^{3} / \mathrm{s}$, respectively (Ward and others, 2000, 2001). Simulated stream base flow in the model for the streamgaging station on the Opequon Creek near Berryville was $0.90 \mathrm{~m}^{3} / \mathrm{s}$. The long-term median and mean streamflow recorded for this station are $0.54 \mathrm{~m}^{3} / \mathrm{s}$ and $1.33 \mathrm{~m}^{3} / \mathrm{s}$, respectively (U.S. Geological Survey, 2008).
Simulated base flow for three additional stations was also within the range of measured base flows. Therefore, base flows simulated by the model, both at the headwaters and at the mouth of the watershed, are considered reasonable based on the calibration data available.

Simulated and measured water levels are strongly correlated (fig. 13), with a correlation coefficient of 0.94 and a normalized root mean squared error of 5.79 percent. Simulation of spring discharge in the model proved difficult as a result of the large potential fluctuations in water levels near springs. A relatively minor change in head near a spring can result in large-magnitude errors in simulated spring discharge. Because of the inherent inaccuracy in simulating spring discharge, no attempt was made to calibrate to specific spring discharges. However, a qualitative comparison to known spring discharges indicated that simulated spring discharges were reasonable.

Several factors limited the accuracy of simulated water levels with respect to measured water levels. First, existing water-level data collected over a 40 -year period were used to develop and calibrate the model. Although the data worked well for developing the steady-state model, they varied widely over varying hydrologic conditions. Therefore, the model was calibrated to the average water levels to approximate an average base-flow condition. In addition, elevations for well measuring points were based on the elevations derived from the DEM, and there are potentially large errors associated with the land-surface elevations assigned to these wells. Finally, the average horizontal error for the well locations, based on data from the GWSI database, can be as much as \pm 10 to 35 $\mathrm{m}$, especially for the older water-level data that were collected prior to the common use of global positioning system (GPS) receivers for establishing location information for wells. An additional limiting factor is that MODFLOW calculates the water level for the center of a node; if the observation well is not located near the center of the node, the difference between the locations of the simulated and measured water levels can be substantial. This error is most pronounced in areas of steep terrain and is as much as $\pm 10 \mathrm{~m}$ at some locations. Fortunately, the areas where topographic effects are pronounced, mainly along the crest of North Mountain, are not areas of emphasis for this study. Given the limitations of assigning elevations to wells and the error associated with topographic effects, the calibration results for hydraulic heads are considered acceptable.

\section{Sensitivity Analysis}

The sensitivity of the model to variations in input parameters, including both horizontal and vertical hydraulic conductivity as well as recharge and anisotropy, was analyzed to provide a measure of the uncertainty of input-parameter values and model output. Estimates of hydraulic conductivity used in the model were based on aquifer-test data collected in the region. Sensitivity-analysis simulations were conducted by varying the input parameters and comparing the root mean squared error to that of the calibrated model. The analyses 


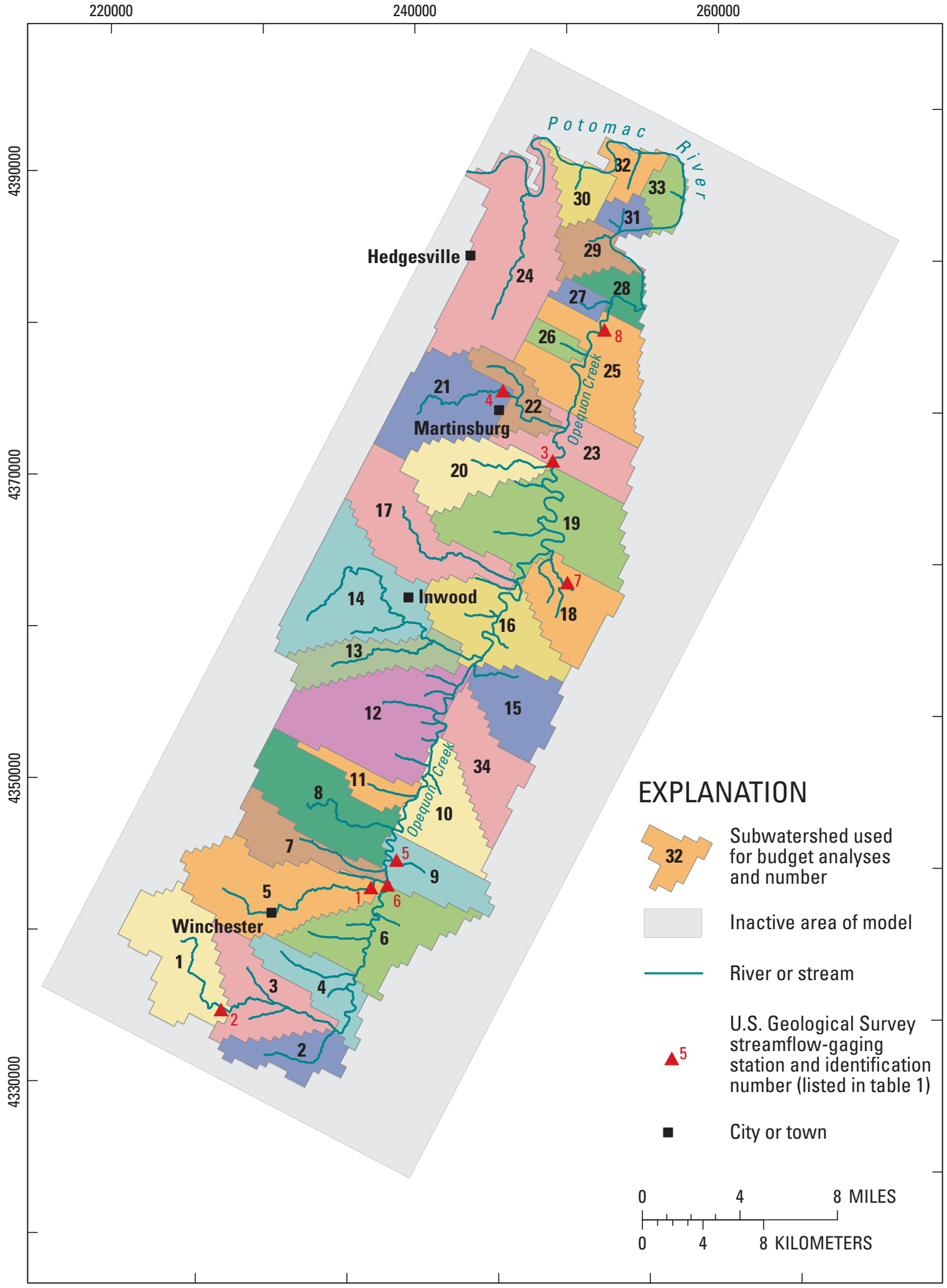

Base from U.S. Geological Survey digital data, Universal Transverse Mercator Projection, Zone 18, NAD 83.

Figure 12. Subwatersheds for which water-budget analyses were conducted in the Opequon Creek watershed area, Virginia and West Virginia. 


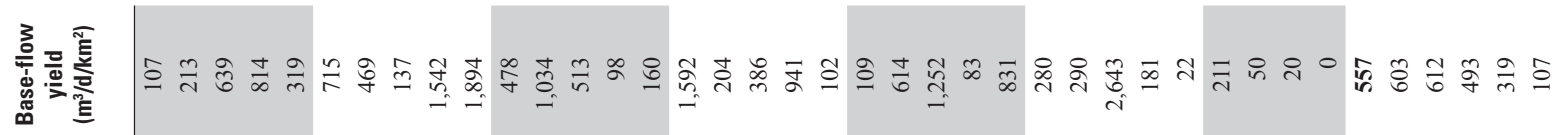

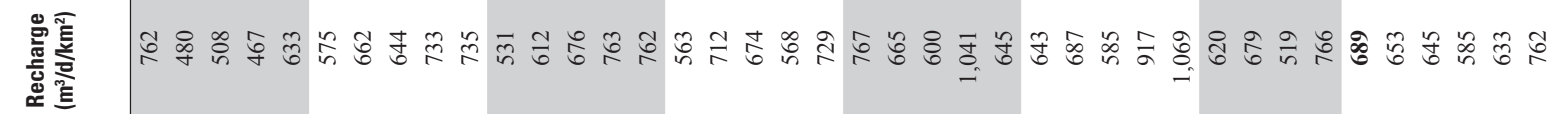

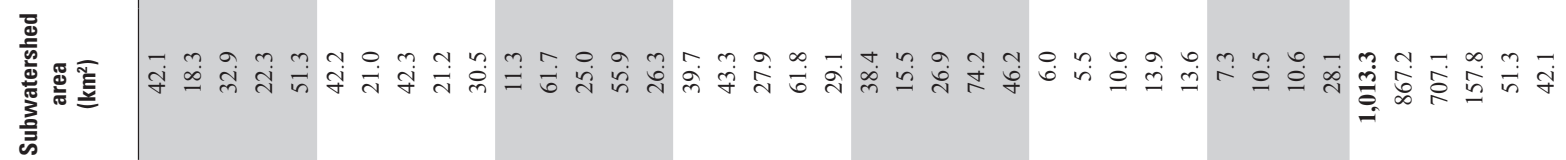

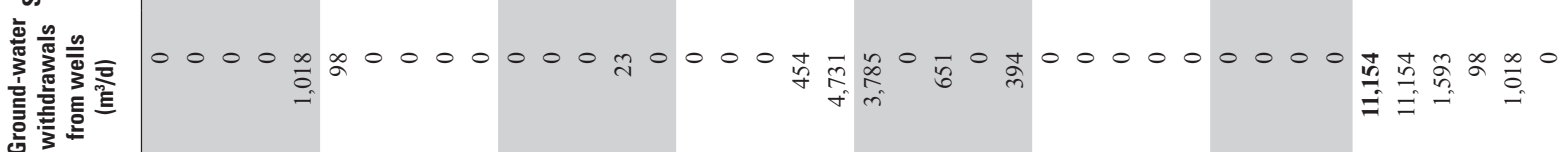

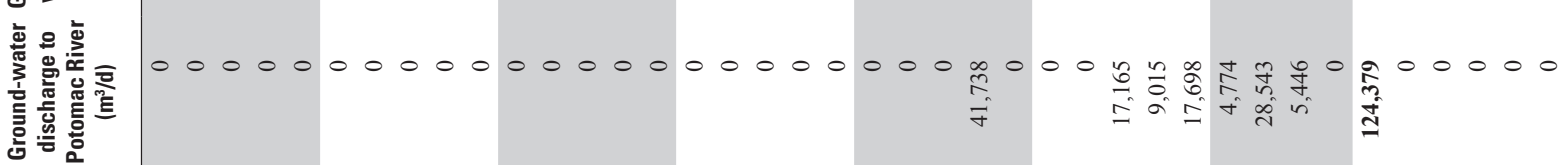

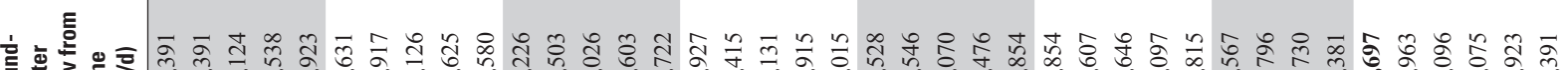

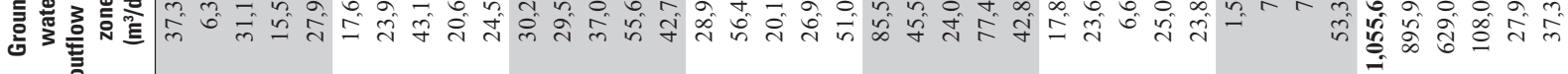

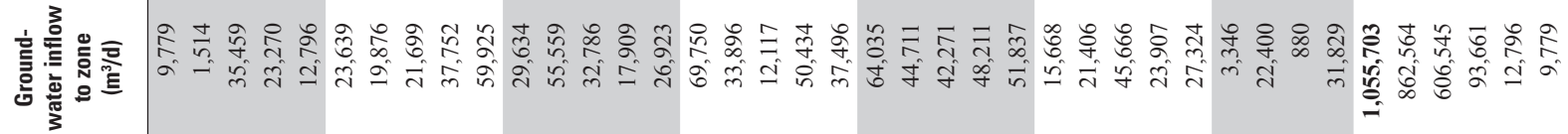

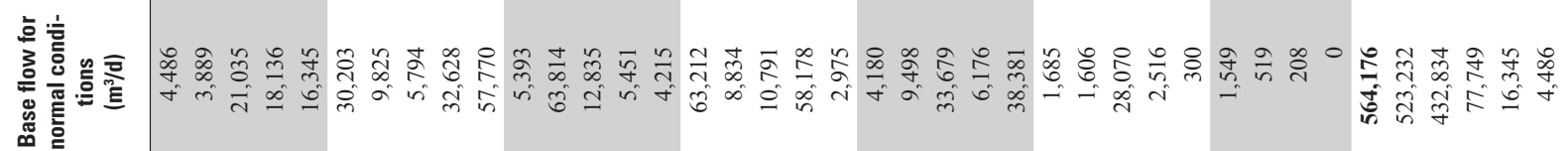

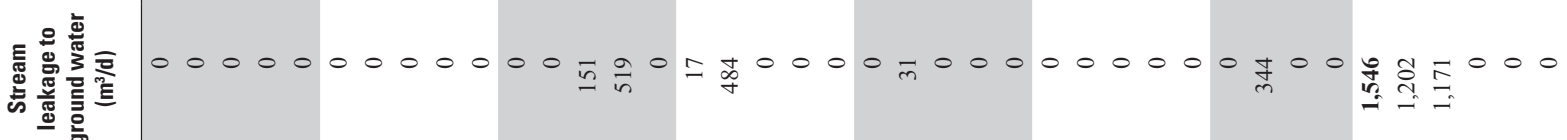

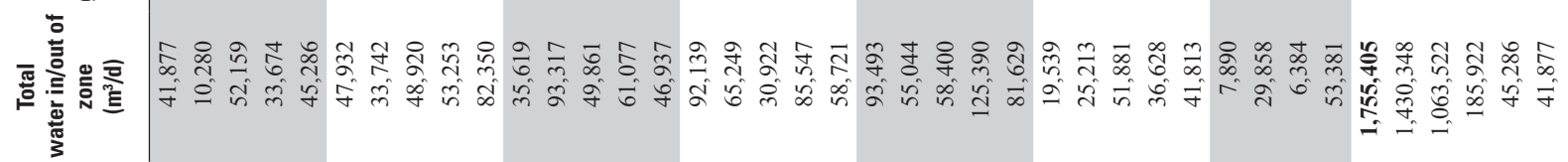

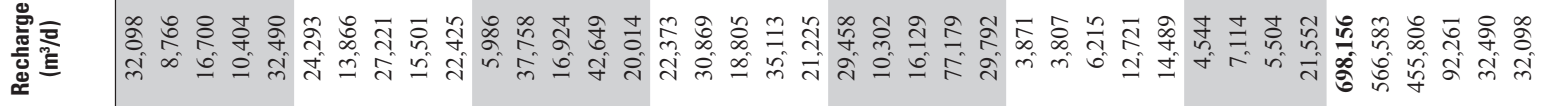
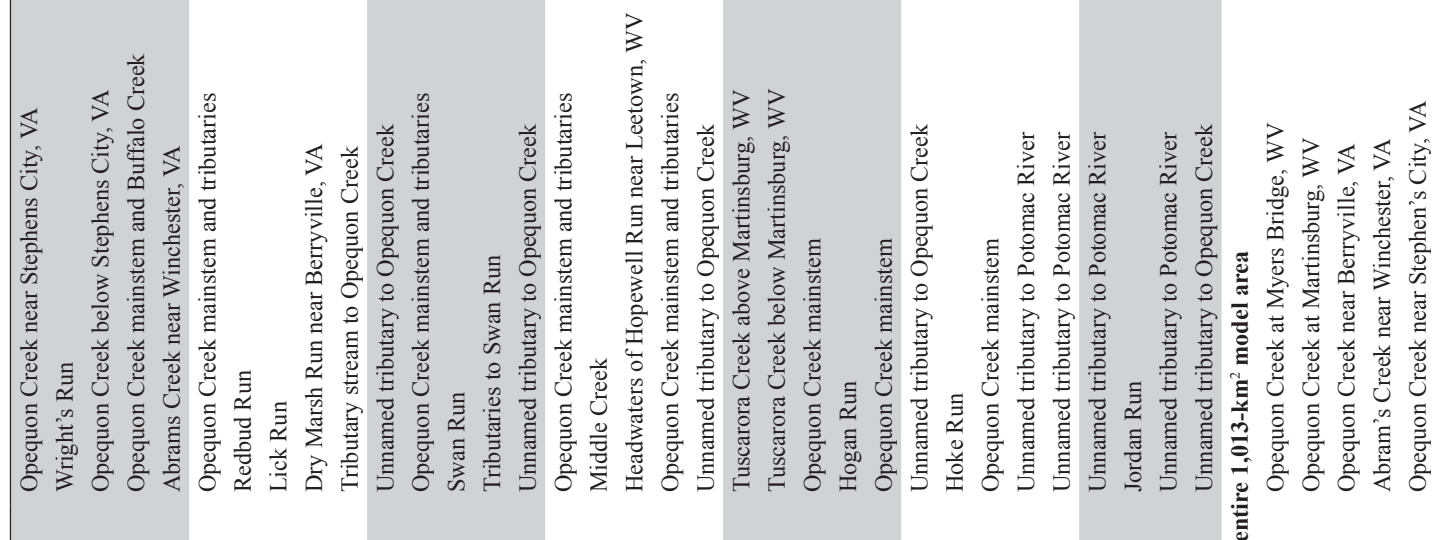


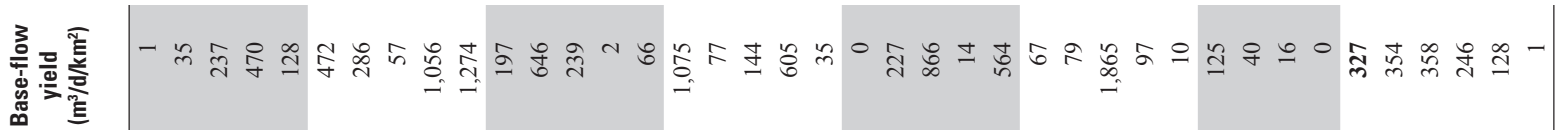

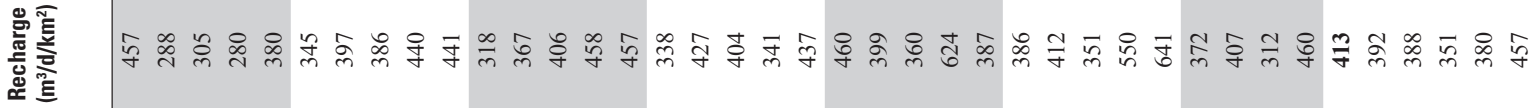

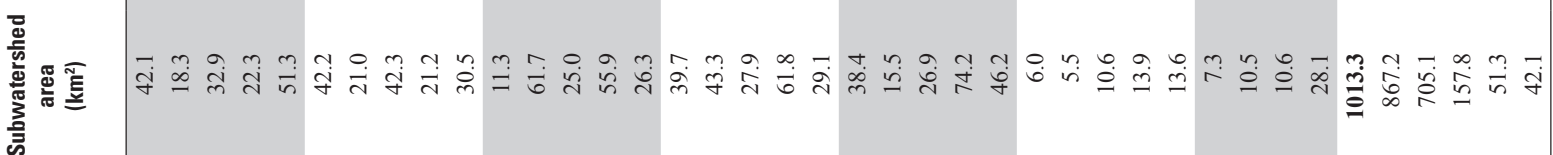

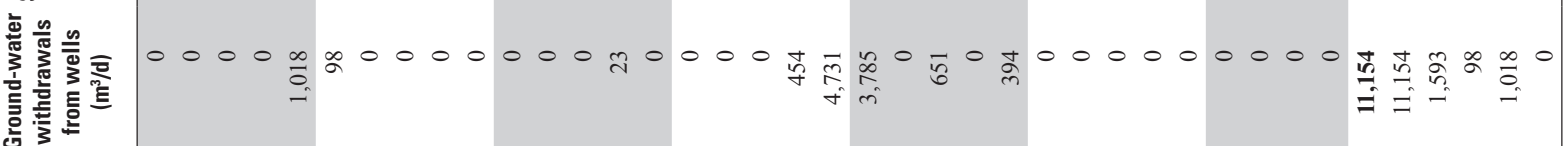

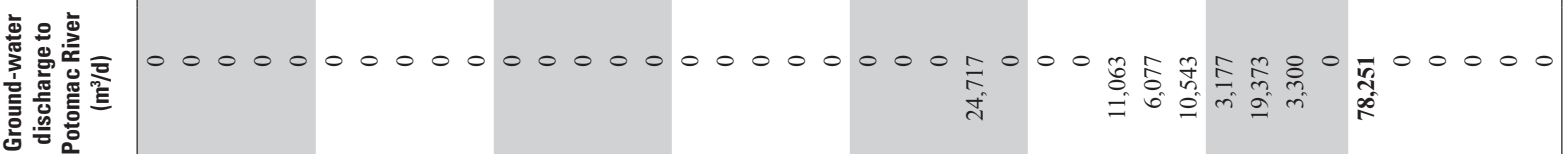

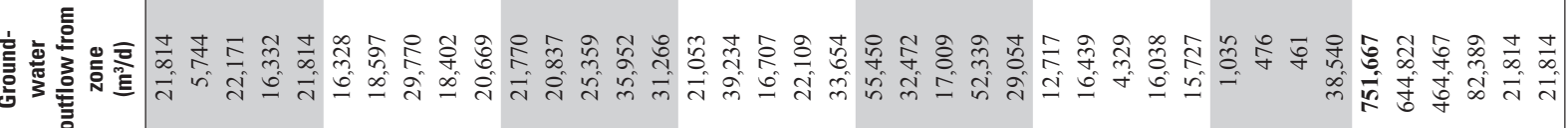

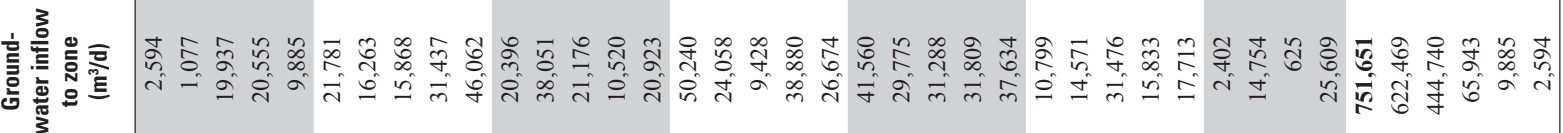

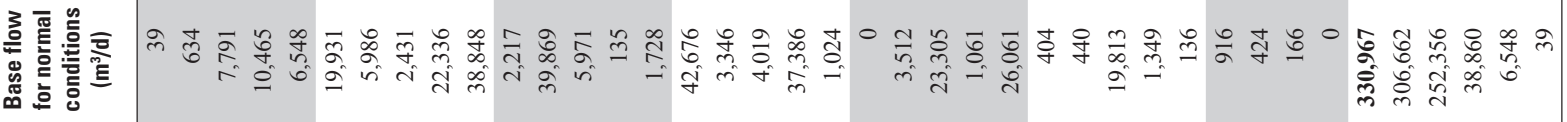

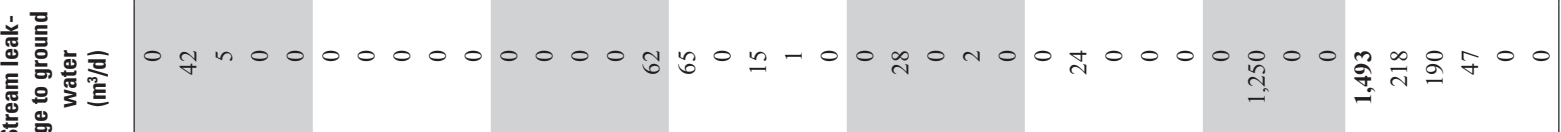

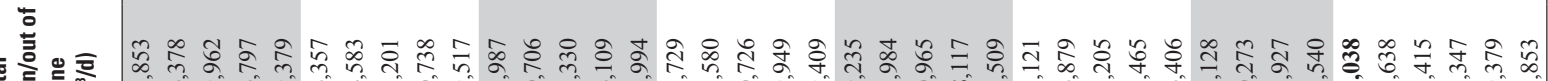

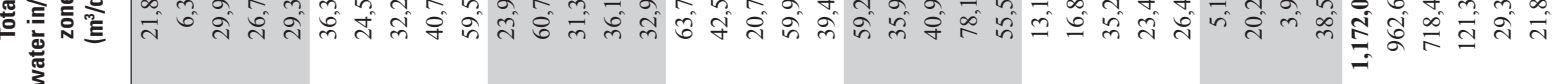

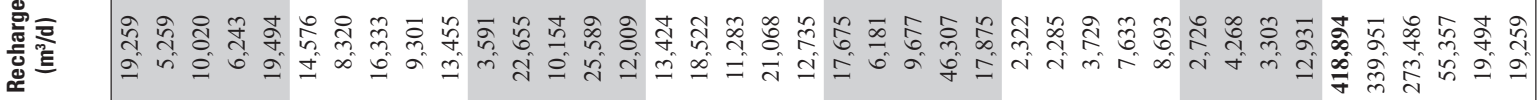

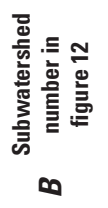
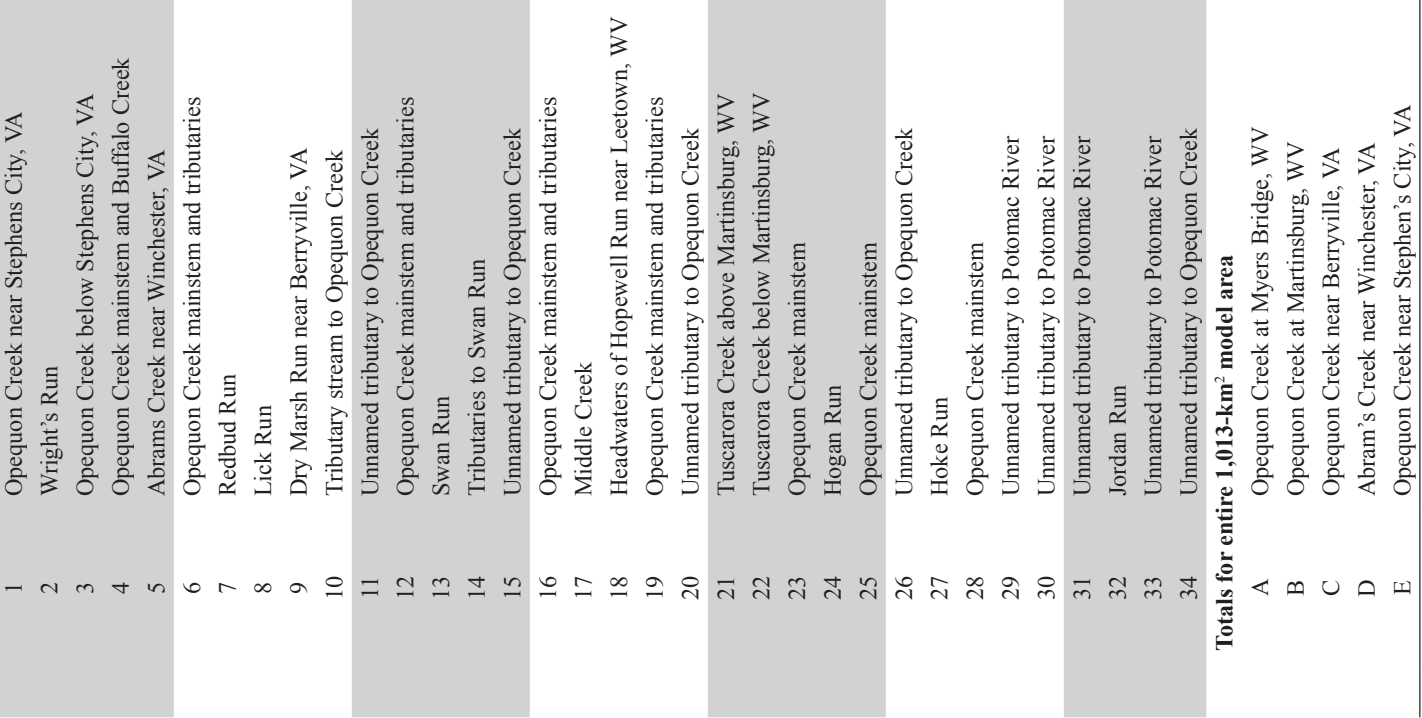

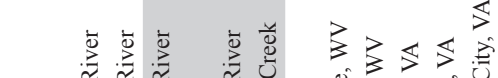

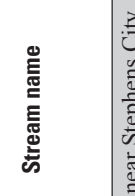




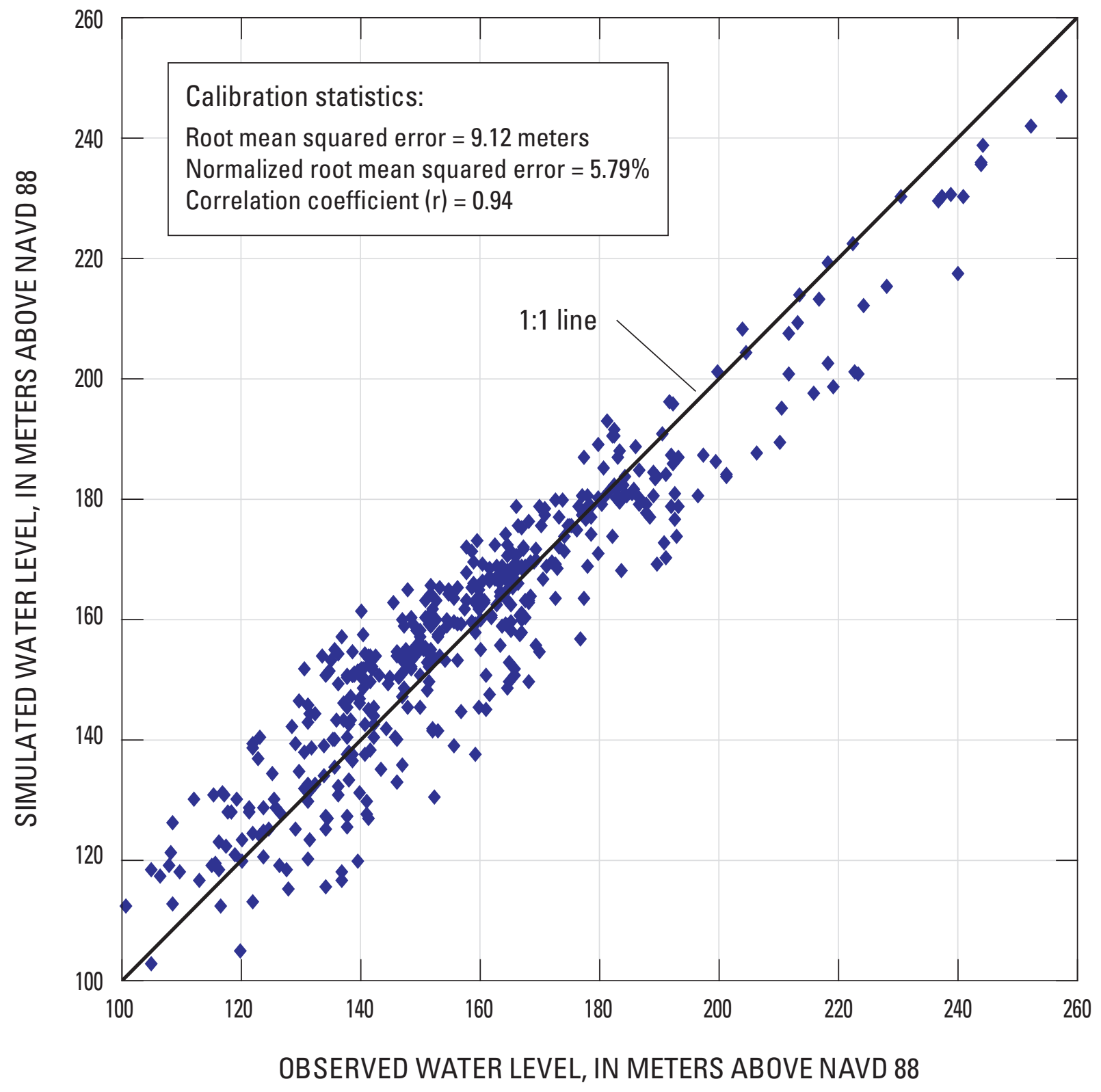

Figure 13. Relation between simulated and observed water levels in 470 observation wells in the Opequon Creek watershed area, Virginia and West Virginia. 
were conducted by multiplying the calibrated parameters by a multiplier (from 0.2 to 2.4-4.0) and examining the resultant change in the root mean squared error of the model. Using a multiplier of 1 results in a value that is equivalent to the value of the calibrated model-input parameter. Changes in potentiometric surfaces and water budgets were also assessed to ensure that realistic values were generated.

Results of the sensitivity analyses (fig. 14) show that the ground-water flow model is most sensitive to recharge and to the values of hydraulic conductivity assigned to the simulated solution conduits, indicating that ground-water flow cannot be realistically simulated without taking into consideration the conduit flow component. Realistic estimates of recharge also are needed to accurately represent base flow and assess the flux of ground water within the model. Recharge for the model was based on analyses of streamflow hydrographs for several USGS streamflow-gaging stations in the watershed and was included in the sensitivity analysis to evaluate its importance for model calibration (table 1). Data from the gaging stations provided very reasonable estimates of recharge for the model and eliminated the need to assign a subjective recharge value. Even minor variations in recharge caused the model output to deviate from the 1:1 calibration line between simulated and observed water level. Therefore, recharge is considered to be the most important parameter for quantifying water budgets in the model.

The model was also somewhat sensitive to the values assigned for hydraulic conductivity of the less permeable geologic formations such as the Conococheague Limestone and Martinsburg and Elbrook Formations. Because the low-permeability geologic units are major controls on ground-water flow, it is not surprising that minor variations in the hydraulic conductivity of these formations would affect simulated heads and the calibration of the model. The model was not sensitive to variations in the hydraulic conductivity assigned to the Silurian and Devonian siliciclastic rocks along North Mountain.

Ratios of horizontal to vertical hydraulic conductivity ranging from 1:1 to 20:1 also were evaluated. Differences in calibration statistics for the various conductivity ratios were minimal, but the 5:1 ratio provided the best fit between simulated and measured water levels and was used for all simulations. The model was also somewhat sensitive to horizontal anisotropy, with an anisotropy of 3:1 in the direction of bedrock strike providing the best fit. In a similar ground-water modeling study of Fredrick County, Virginia, the optimal anisotropy in the direction of bedrock strike was also found to be 3:1 (Burbey, 2003)

\section{Water Budgets}

A water budget is a mass balance of inputs to and outputs from a watershed. The major input to the ground-water flow model was recharge derived from precipitation. One small wastewater-treatment plant return flow provides water initially derived from the Shenandoah River, but the quantity is negligible when compared to the total water balance for the watershed. No other inputs to the watershed were evident in the study area. Outputs from the model include base flow, consumptive use of water from wells, evaporation of water from land and water surfaces, and transpiration of water by trees, grasses, and other vegetation. Precipitation for the study area was based on records (National Oceanic and Atmospheric Administration, 2002a, 2002b) collected at five National Weather Service meteorological stations (table 2). Long-term mean precipitation for two stations, the Martinsburg Regional Airport, West Virginia, and the Winchester 3ESE, Virginia, weather stations, provided data for water-budget calculations. Mean precipitation for Martinsburg for the period 1926-2007 was $960 \mathrm{~mm} / \mathrm{yr}$ and mean precipitation for Winchester for the period 1912-2007 was $957 \mathrm{~mm} / \mathrm{yr}$ (National Oceanic and Atmospheric Administration, 2008). The major output, average streamflow of the Opequon Creek near Martinsburg, was available from existing data (U.S. Geological Survey, 2008b), and was approximately $311 \mathrm{~mm} / \mathrm{yr}$. The difference between the long-term average base flow and the long-term average recharge is attributable mostly to surface runoff and evapotranspiration. The water budget can be expressed by the equation

$$
P=S R O+G W D+E T+\Delta S,
$$

where
$P \quad$ is the total precipitation,
$S R O$ is the component of streamflow that occurs as a result of surface runoff,
GWD is the ground-water discharge to the stream (stream base flow),
ET is evapotranspiration, and
$\Delta S \quad$ is the change in ground-water storage.

As long-term streamflow and precipitation data were used to develop the water budget, change in storage $(\Delta S)$ was assumed to be negligible. Therefore, the only unmeasured quantity was $E T$, which was estimated by difference. Given an average long-term measured precipitation of $958 \mathrm{~mm} / \mathrm{yr}$ (average of the values from the Martinsburg and Winchester meteorological stations), total streamflow of $311 \mathrm{~mm} / \mathrm{yr}$ (surface runoff of $101 \mathrm{~mm} / \mathrm{yr}$ and base flow (ground-water discharge) of $210 \mathrm{~mm} / \mathrm{yr}$ ), the water-budget equation was rearranged to solve for $E T$ by filling in the known terms:

$$
\begin{gathered}
E T=P-(S R O+G W D+\Delta S) \\
E T=958-(101+210)=647 \mathrm{~mm} / \mathrm{yr} .
\end{gathered}
$$

Once $E T$ has been estimated, the complete water budget equation can then be written as

$$
\begin{gathered}
P=S R O+G W D+E T+\Delta S, \\
958=101+210+647-0.0 \mathrm{~mm} / \mathrm{yr},
\end{gathered}
$$

with all terms expressed in millimeters per year. 

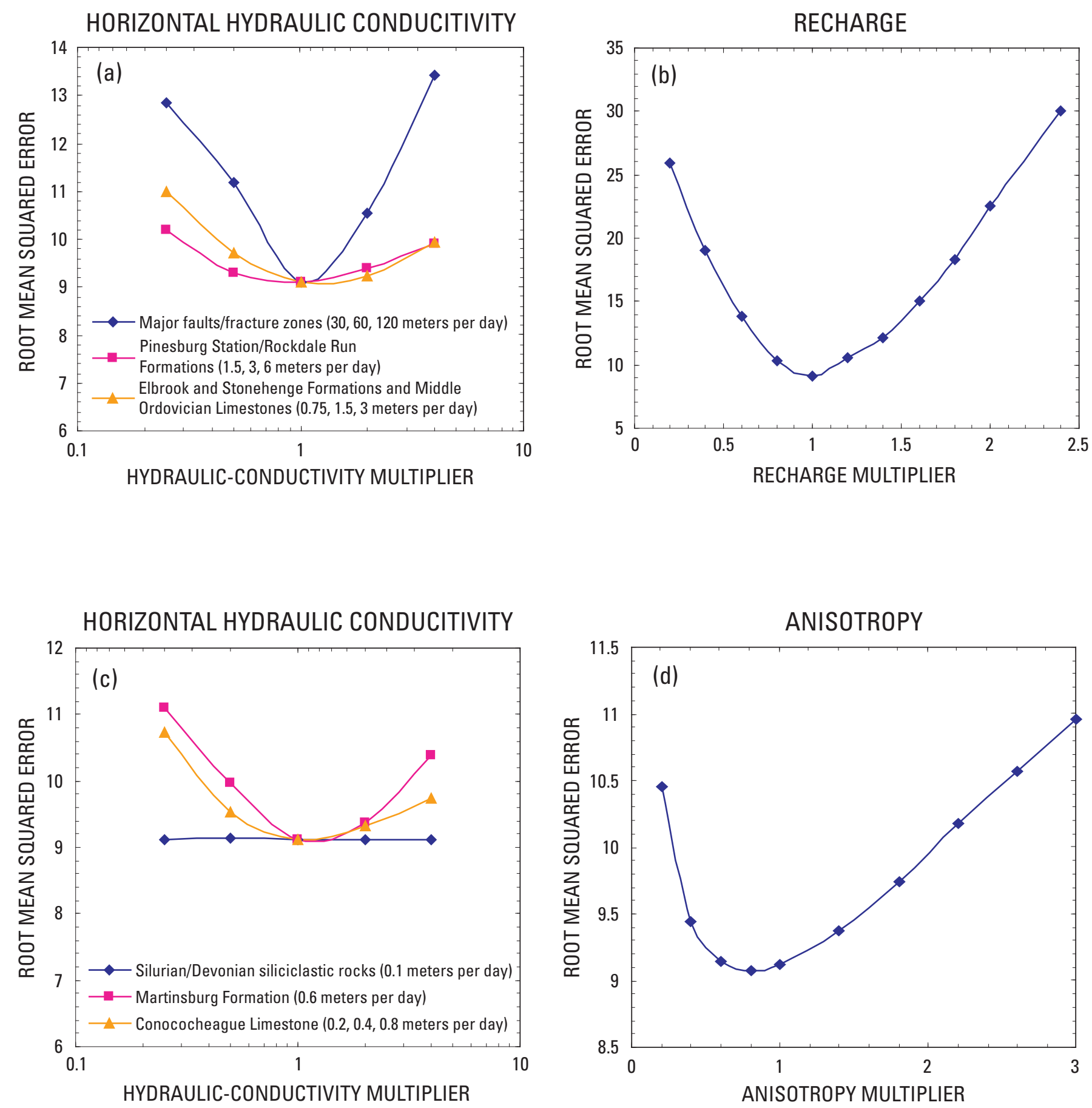

Figure 14. Results of sensitivity analyses of major input parameters for the ground-water flow model of the Opequon Creek watershed area, Virginia and West Virginia. 
The water budget presented here is approximate and may have appreciable error as a result of variations in precipitation across the watershed (table 2). Therefore, the water-budget estimate of $E T$ should be regarded as approximate only. The estimates for ground-water discharge and surface runoff are, however, well defined as they are based on historical streamflow data.

The effective mean recharge estimated by hydrograph separation of streamflow (Kozar and Mathes, 2001) for the Opequon Creek near Martinsburg streamflow-gaging station (table 1) was $241 \mathrm{~mm} / \mathrm{yr}$. This value compares favorably to the simulated ground-water recharge of $235 \mathrm{~mm} / \mathrm{yr}$ over the $707-\mathrm{km}^{2}$ drainage area of the gaging station on the Opequon Creek near Martinsburg estimated by the ground-water flow model. The minor difference between recharge $(235 \mathrm{~mm} / \mathrm{yr})$ and ground-water discharge $(210 \mathrm{~mm} / \mathrm{yr})$ may be attributable to riparian evapotranspiration and (or) to subtle differences in mathematical analyses and computations used in the two methods.

Recharge was set to 150,280 , or $390 \mathrm{~mm} / \mathrm{yr}$ on the basis of the proportion of carbonate bedrock and potential for deep weathering of the bedrock. Approximately 68 percent of precipitation is lost to evapotranspiration. Based on hydrograph separation of annual mean daily streamflow data for the Opequon Creek near Martinsburg streamflow-gaging station, approximately 68 percent of streamflow is derived from ground-water discharge and 32 percent is attributed to surface runoff. These estimates compare favorably with the water-budget estimates calculated for the Hopewell Run watershed area (Kozar and others, 2007, 2008), where $E T$ was approximately 63 percent of total precipitation but base flow accounted for 93 percent of total streamflow and only 7 percent of surface runoff. The Hopewell Run is a tributary to the Opequon Creek and the two watersheds have similar hydrogeologic settings, with the Hopewell Run watershed consisting of a much larger percentage of highly permeable carbonate bedrock than the larger Opequon Creek watershed.

Analyses of the subwatershed water budgets for average hydrologic conditions are presented in table 6a. Areas composed solely of limestone bedrock, as would be expected, have higher recharge rates than areas dominated by shale bedrock.

Areas where the bedrock is more evenly divided between carbonate and shale bedrock are intermediate with respect to recharge. Of five streamflow-gaging stations analyzed, Opequon Creek near Stephens City, Virginia, had the highest recharge rate $\left(762 \mathrm{~m}^{3} / \mathrm{d} / \mathrm{km}^{2}\right)$, and Opequon Creek near Berryville, Virginia, had the lowest recharge rate $\left(585 \mathrm{~m}^{3} / \mathrm{d}^{\mathrm{k}} \mathrm{km}^{2}\right)$. The drainage area for Opequon Creek near Stephens City is composed almost entirely of carbonate limestone and dolomite bedrock, whereas a substantial proportion of the drainage area of Opequon Creek near Berryville is non-carbonate shale of the Martinsburg Formation.

Recharge rates were highest $\left(>1,000 \mathrm{~m}^{3} / \mathrm{d} / \mathrm{km}^{2}\right)$ in the northern portion of the basin in the Hogan Run watershed near Hedgesville, W.Va., and in a few of the tributaries that drain directly to the Potomac River (table 6). These areas (zones 24 and 30 in figure 12) are dominated by numerous cross-strike faults (fig. 2a). The subwatershed budgets also indicate that a substantial amount of ground water in the small subwatersheds in the northern portion of the basin discharges directly to the Potomac River. Base flow in these steams is typically very low, as the depth to ground water can exceed $50 \mathrm{~m}$. Total recharge $\left(698,156 \mathrm{~m}^{3} / \mathrm{d}\right)$ distributed over the entire $1,013-\mathrm{km}^{2}$ watershed is $689 \mathrm{~m} / \mathrm{d} / \mathrm{km}^{2}$ (table $6 \mathrm{a}$ ). Because specific streamflow data for calibration of simulated streamflow in many of the subwatersheds were unavailable, estimates of recharge and base-flow yield for the individual subwatersheds should be regarded only as rough approximations.

Simulated base-flow yields ranged from 0 to approximately $2,643 \mathrm{~m}^{3} / \mathrm{d} / \mathrm{km}^{2}$ for average conditions and from 0 to $1,865 \mathrm{~m}^{3} / \mathrm{d} / \mathrm{km}^{2}$ for the simulated drought (table $6 \mathrm{~b}$ ). These values generally agree with the range of base-flow yields determined for the West Virginia portion of the Opequon Creek watershed in Berkeley County of -879 to $2,140 \mathrm{~m}^{3} / \mathrm{d} / \mathrm{km}^{2}$ (Evaldi and Paybins, 2006a, 2006b). However, the Berkeley County, W.Va., base-flow-yield assessment was based on channel gains and losses and was conducted when hydrologic conditions were wetter than during the 1999 drought. Therefore, computed base-flow yields were negative where discharge decreased downstream but the values presented in table 6 cannot be less than zero. Simulated base-flow yields were expected to be slightly lower than those documented in the Berkeley County channel gains and losses study. Several stream reaches did show loss of streamflow to ground water (table 6) and several streams dried up completely in the drought simulation. Although the Opequon Creek at Stevens City streamflow-gaging station was not operational during the 1999 drought, annual low flows less than $1 \mathrm{~m}^{3} / \mathrm{s}$ are common for that portion of the watershed (U.S. Geological Survey, 2008c).

Major production wells (both public supply and industrial) account for approximately 2 percent of ground-water recharge from the watershed upstream from the Opequon Creek near Martinsburg streamflow-gaging station during average flow conditions (table 6a). For a simulated drought, withdrawals as a percentage of overall ground-water recharge increase to approximately 3.2 percent (table 6b). Withdrawals from individual wells account for additional consumptive use, although quantification of the loss is difficult. A large portion of water withdrawn by individual residential wells is returned to the aquifer as septic-system return flows.

\section{Ground-Water Flow Directions}

Ground-water flow directions were analyzed by examining the hydraulic-head equipotentials in the upper layer of the model. Generally, ground water flows from topographically high areas toward Opequon Creek. The low hydraulic conductivity of the Martinsburg and Elbrook Formations and Conococheague Limestone (fig. 2) plays an integral role by retarding flow of ground water. Water is forced to travel roughly parallel to bedrock strike along a series of thrust faults (fig. 2) that 
parallel these lower permeability formations and act as drains, conveying water northward toward tributary streams that cross the thrust faults at roughly 90 degrees. Cross-strike faults allow water to cross the lower permeability bedrock and flow toward Opequon Creek. These complex geologic features are responsible for the large springs in the region. These processes are especially prominent where carbonate bedrock and thrust faults are in close proximity to the Martinsburg Formation, which is composed of low-permeability shale. Chemically aggressive water from the Martinsburg Formation enhances solution of carbonate rocks, forming conduits. There is an overall trend of flow not only toward Opequon Creek, but also from south to north in the Opequon Creek watershed area. Modeled directions of ground-water flow are outlined in figure 15. Thus, much of the ground water resident in the southern portion of the watershed is flowing toward Opequon Creek, but some ground water flows northward into West Virginia.

\section{Simulated Flow for Average Conditions}

The ground-water flow model for the Opequon Creek watershed area was developed and calibrated for average hydrologic conditions. Recharge applied in the model was apportioned with respect to the permeability of the various geologic formations. The resulting water-budget calculations (table 6a) and simulated potentiometric surface therefore reflect average conditions (fig. 15). For the model, recharge to the Opequon Creek watershed area upstream from the Martinsburg streamflow-gaging station was 455,806 m²/d $\left(646 \mathrm{~m}^{3} / \mathrm{d} / \mathrm{km}^{2}\right)$ and simulated base flow was $432,834 \mathrm{~m}^{3} / \mathrm{d}$ $\left(614 \mathrm{~m}^{3} / \mathrm{d} / \mathrm{km}^{2}\right)$. The difference between the recharge and the simulated base flow can be attributed to a number of factors, including evapotranspiration, transfer of ground water out of the watershed, or loss of streamflow to ground water. Simulated recharge over the entire $1,013-\mathrm{km}^{2}$ model area under average hydrologic conditions was $698,156 \mathrm{~m}^{3} / \mathrm{d}$ $\left(689 \mathrm{~m}^{3} / \mathrm{d} / \mathrm{km}^{2}\right)$. Mean and median measured streamflow for the Opequon Creek near Martinsburg streamflow-gaging station are 604,384 and $349,907 \mathrm{~m}^{3} / \mathrm{d}$, respectively (U.S. Geological Survey, 2008b). Therefore, the simulated base flow of $432,834 \mathrm{~m}^{3} / \mathrm{d}$ for the watershed upstream from the Opequon Creek near Martinsburg station falls between the mean and median streamflow measured at this station.

Given the drainage areas of Opequon Creek and its tributaries (table 5), it is possible to calculate the average base-flow discharge rate from the Opequon Creek watershed area or its tributaries. This was done for the simulation using the Zonebudget calculations within the Visual MODFLOW software. Base-flow discharge estimates (table 6) provide a basis for management of long-term water availability. Water availability is limited not by average conditions but instead by periods of low flow; water-use planners need to take into consideration the quantity of water available during critical periods of low flow, such as those that occur in late summer or early fall.
Examination of simulated water budgets indicates that a substantial component of discharge to the Potomac River is through direct ground-water discharge. This phenomenon has long been suspected but now has been quantified. During average conditions, simulated base-flow discharge to the Potomac River was $564,176 \mathrm{~m}^{3} / \mathrm{d}\left(6.53 \mathrm{~m}^{3} / \mathrm{s}\right)$. An additional $124,379 \mathrm{~m}^{3} / \mathrm{d}\left(1.44 \mathrm{~m}^{3} / \mathrm{s}\right)$ of ground water is also estimated to discharge to the Potomac River and represents approximately 18 percent of the total discharge to the Potomac River. This additional ground water discharges along strike-parallel faults and fracture zones and as springs along the southern margin of the Potomac River. Direct ground-water discharge to the Potomac River is difficult to measure as a result of the locks and dams on the river, ground-water and spring discharges within the river, and tributary drainage from the Maryland side of the river. Although the simulation provides only an initial estimate of ground-water discharge to the Potomac River, it does at least indicate that this discharge is a mathematically reasonable hypothesis.

\section{Simulated Flow for Drought Conditions}

In order to provide an estimate of ground-water availability during critical low-flow periods, the ground-water model was used to simulate ground-water flow conditions for a drought period. Recharge was reduced to simulate the drought that affected the Shenandoah Valley from November 1998 through February 2000. This was the fourth most severe drought on record for the region with respect to precipitation deficits and was the longest drought on record, lasting 16 months (Cornell University, 2008). The base-flow estimates generated during the simulated drought can provide water planners with estimates of water availability for critical lowflow periods.

Recharge to the model was reduced 40 percent from average values to approximate recharge during the drought. The resulting water budgets (table 6b) and potentiometric surface (fig. 16) simulate severe drought conditions and provide a baseline for consideration in future water-management issues. The recharge applied to the model for the Opequon Creek watershed area upstream from the Martinsburg streamflowgaging station was $273,486 \mathrm{~m}^{3} / \mathrm{d}$ and simulated base flow for the Opequon Creek upstream from the station during the 1999 drought was approximately $252,356 \mathrm{~m}^{3} / \mathrm{d}\left(2.95 \mathrm{~m}^{3} / \mathrm{s}\right)$. Mean and median streamflow records for the Opequon Creek near Martinsburg station for the 16-month drought period were $341,098\left(3.95 \mathrm{~m}^{3} / \mathrm{s}\right)$ and $216,551 \mathrm{~m}^{3} / \mathrm{d}\left(2.51 \mathrm{~m}^{3} / \mathrm{s}\right)$, respectively (Ward and others, 2000, 2001). Therefore, the simulated drought base-flow discharge for the Opequon Creek near Martinsburg station falls between the mean and median streamflow measured during the 16-month drought. Recharge was $388 \mathrm{~m}^{3} / \mathrm{d} / \mathrm{km}^{2}$ for the watershed upstream from the Opequon Creek near Martinsburg station, and $413 \mathrm{~m}^{3} / \mathrm{d} / \mathrm{km}^{2}$ over the entire watershed. Once again the difference between the recharge and simulated base flow can be attributed to a number of factors, including evapotranspiration by riparian 


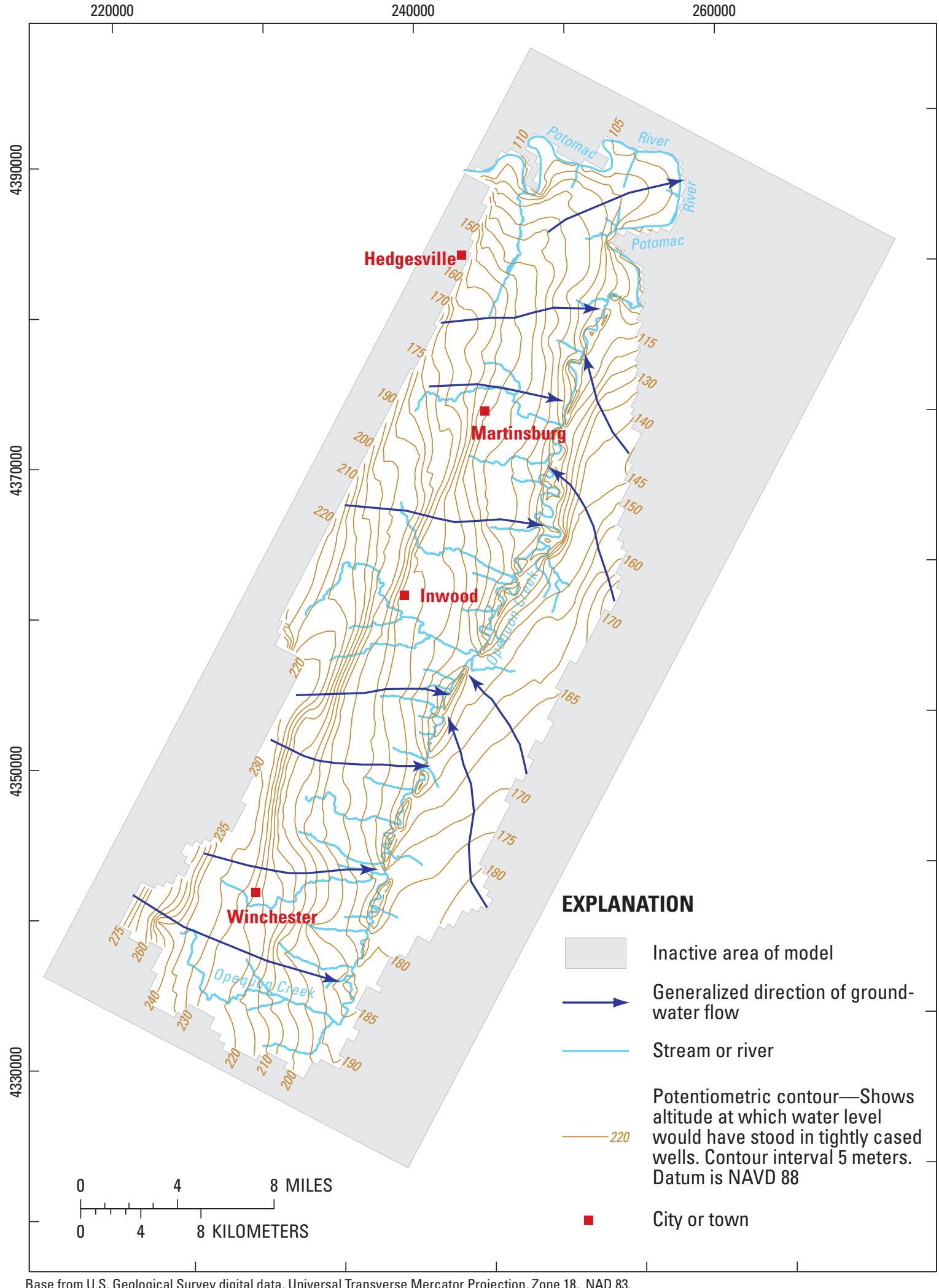

Figure 15. Simulated potentiometric surface and generalized directions of ground-water flow for average hydrologic conditions in the Opequon Creek watershed area, Virginia and West Virginia. 
vegetation, transfer of ground water out of the watershed, or loss of streamflow to ground water. Table $6 \mathrm{~b}$ provides recharge and base-flow estimates for Opequon Creek and its tributaries that can be used to obtain estimates of water availability in the Opequon Creek watershed area during critical low-flow periods. Because streamflow data for the 16-month drought were unavailable for calibration of simulated streamflow, estimates of recharge and base-flow yield for the individual subwatersheds should be regarded as rough approximations only.

\section{Limitations of the Simulations}

A major limitation of ground-water modeling in karst terranes is difficulty in accurately simulating potentiometric heads (ground-water levels). A 2- or 3-m difference between simulated and measured ground-water levels for a model of the scale described in this report is considered a very good calibration match; however, such a difference in water levels in the vicinity of springs is problematic. In addition, simulated potentiometric heads typically were slightly lower than water levels measured along North Mountain as a result of the pronounced topographic relief there.

Another major limitation of ground-water modeling in karst terranes is accurate simulation of spring discharge. It is extremely difficult to simulate spring discharge accurately in a karst aquifer such as that typified by the study area. Springs can be simulated either as withdrawal points (pumped wells), as drains, or as streams, but each approach has its limitations. If springs are simulated as withdrawals (pumped wells), a precise discharge can be specified but cones of depression are commonly observed in such an approach (Early, 2005), which is not realistic. Simulation of springs as drains does not allow a flux of water from streams back to ground water, as can occur in karst terranes. If springs are simulated as streams, then spring discharge is susceptible to small changes in nearby ground-water levels, making accurate estimation of spring discharge difficult. Because estimation of spring discharge was secondary to accurate estimation of base flow, springs were simulated as streams forming the headwaters of tributaries draining to Opequon Creek. However, water budgets resulting from a numerical simulation of ground-water flow are less affected by these limitations and provide estimates that accurately simulate the base flow measured at the various streamflow-gaging stations within the watershed.

The steady-state model of ground-water flow in the Opequon Creek watershed area was calibrated against 470 water levels retrieved from the GWSI database. These water-level data were collected under varying hydrologic conditions over a 40-year timeframe. In addition, the wells in this study were open to different depths within a given model layer, and potentially to multiple geologic formations. There is also a margin of error associated with the location and altitude of wells for which water-level measurements were available that could skew the distribution between simulated and observed water levels. Obvious outlier data were removed from the data set and the model was calibrated to the centroid of the water-level data. Therefore, the model is considered calibrated to average water-level conditions. Because ground-water level data for the 16-month actual drought period were unavailable for calibration of water levels during the simulated drought period, the resultant potentiometric surface and subwatershed water budgets should be regarded as estimates only. The simulations presented here represent average hydrologic conditions and conditions during the November 1998 through February 2000 drought, and are based on the best available data, but actual ground-water levels may be greater (higher) or less (lower) than those simulated.

As stated above, the ground-water flow model was calibrated to steady-state conditions and represents long-term average conditions. However, short-term water budgets can vary substantially from long-term steady-state conditions. Although the water-budget estimates for the four gaging stations on Opequon Creek are reasonable, budget information for the subwatersheds should be regarded as estimates only because of the lack of data specific to the subwatersheds and the hydrologic conditions simulated. Differences between simulated and actual recharge, base-flow yields, and channel gains and losses are possible.

\section{Summary and Conclusions}

This report presents results of a steady-state simulation of ground-water flow developed in 2008 for the Opequon Creek watershed area in the northern Shenandoah Valley of Virginia and West Virginia. The resulting model was used to develop a budget of available ground-water resources and to assess the potential effects of drought on water availability within the watershed. The report describes the hydrogeology of the study area, documents the development of the ground-water flow model, presents the results of water-budget analyses, and quantifies simulated streamflow under both average and drought conditions. This report was prepared in cooperation with the West Virginia Department of Health and Human Services and the West Virginia Department of Environmental Protection.

Ground-water flow in the 1,013- $\mathrm{km}^{2}$ Opequon Creek watershed area in Virginia and West Virginia was simulated using a three-dimensional finite-difference model. The steadystate ground-water flow model was developed by extrapolating the conceptual model of ground-water flow developed for the smaller watershed of Hopewell Run $\left(52 \mathrm{~km}^{2}\right)$, which is a tributary to the much larger Opequon Creek. The model for the Opequon Creek watershed area was used to develop a water budget for the watershed and assess the potential effects of drought on water availability within the watershed.

The study area is dominated by karstic carbonate rocks of Cambrian and Ordovician age. Ground water flows through diffuse fractures and small, solutionally enlarged conduits, which serve as drains for the dominant diffuse system of interconnected fractures. Shallow ground-water flow occurs in 


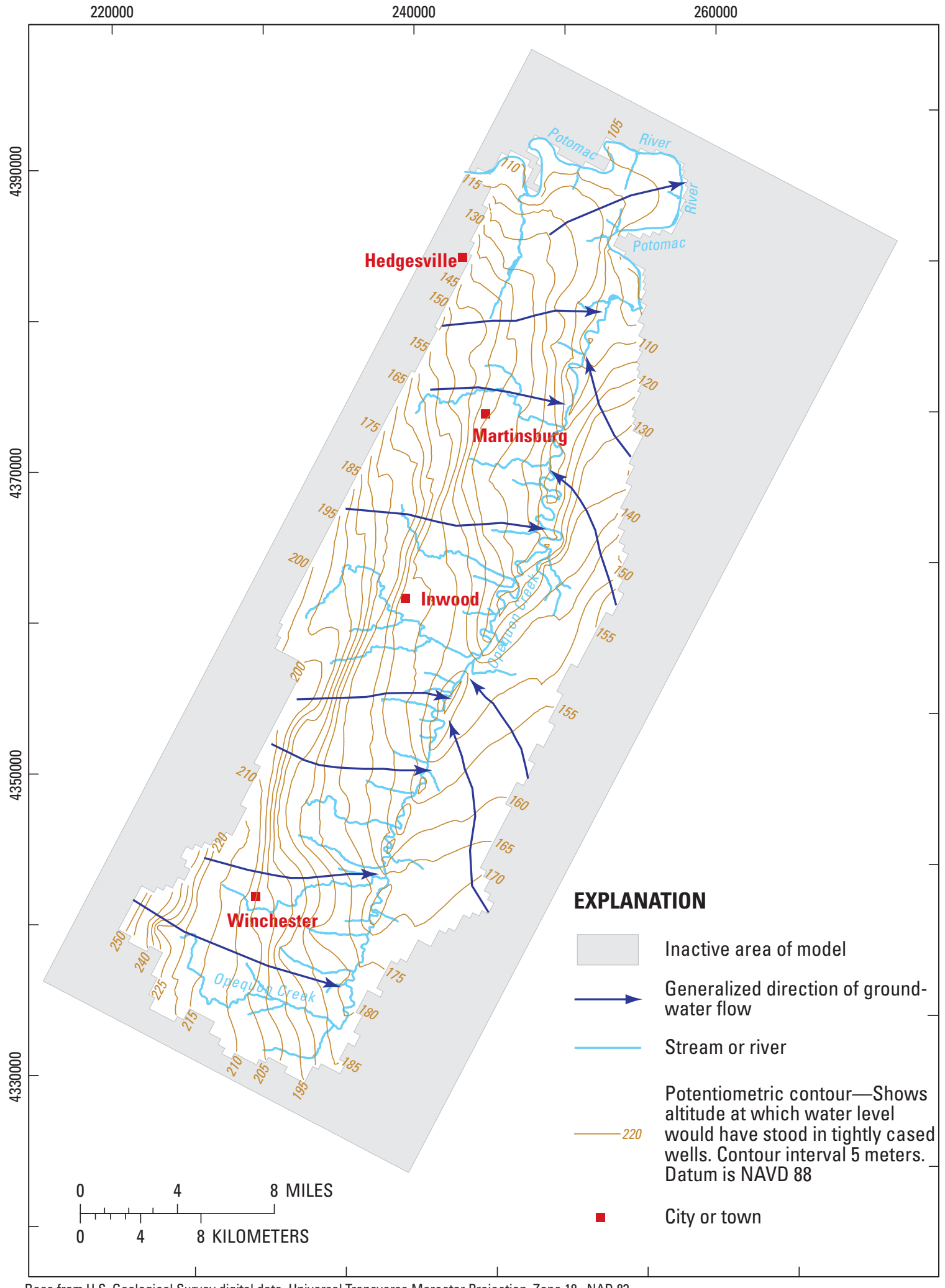

Figure 16. Simulated potentiometric surface for drought conditions (November 1998-February 2000) in the Opequon Creek watershed area, Virginia and West Virginia. 
an epikarstic zone that extends from land surface to a depth of 9 to $20 \mathrm{~m}$. Most of the residential, production, and commercial wells in the study area are completed in the interval from about 25 to $100 \mathrm{~m}$ below land surface. Hydraulic conductivity decreases with depth in the bedrock aquifer, and ground-water flow occurs primarily in the upper $100 \mathrm{~m}$ of bedrock. Solutionally enlarged conduits are less pervasive at depths below about $50 \mathrm{~m}$. Recharge is areally diffuse, occurring over a broad area with minimal focused recharge to sinkholes.

Geologic structure is a major control on ground-water flow. Strike-parallel thrust faults and cross-strike faults or fracture zones act as drains that funnel large quantities of water through the Opequon Creek watershed area. Poorly permeable bedrock such as the Conococheague Limestone and Martinsburg Formation, acts as a barrier to ground-water flow and retards its downgradient movement. This barrier effect causes ground water to flow laterally along bedding planes and thrust faults. Cross-strike faults and fracture zones allow ground water to flow through the less permeable units.

A three-layer steady-state numerical ground-water flow model was developed to represent the aquifer based on this conceptual understanding of ground-water flow. The epikarstic near-surface part of the aquifer was represented by the upper layer of the model, which extends from land surface to a depth of about $35 \mathrm{~m}$. The intermediate zone, in which most wells are completed, was represented by the middle layer of the model, and extends from 35 to $100 \mathrm{~m}$ below land surface. The less fractured, deepest part of the bedrock aquifer was represented by the lower layer of the model, which extends from 100 to approximately $185 \mathrm{~m}$ below land surface. Areally diffuse recharge was applied to the entire model at rates (average $241 \mathrm{~mm} / \mathrm{yr}$ ) based on estimates of ground-water recharge provided by analyses of streamflow at three USGS streamflow-gaging stations, increasing proportionally with the percentage of carbonate rocks and (or) depth of bedrock weathering. Estimates of hydraulic conductivity were made based on results of aquifer tests conducted as part of recent fracture-trace and lineament analysis investigations in Jefferson and Berkeley Counties, West Virginia, and on results of single- and multi-well aquifer tests conducted as part of an intensive hydrogeologic investigation of the Hopewell Run watershed. Geologic mapping, conducted as part of recent and past investigations, provided the locations of faults and identified the geologic formations that crop out in the area.

Boundary conditions for the model included river (constant-head) cells along the Potomac River at the northern boundary of the model and no-flow cells representing bedrock ridges separating watersheds along the eastern and southern boundaries of the model and along North Mountain to the west. Hydraulic conductivities assigned to the model were based on geologic formations mapped in the area and on the results of aquifer tests. Faults were represented by zones of higher hydraulic conductivity to simulate conduit drains.

The model was calibrated based on recharge estimated from streamflow data collected at long-term USGS streamflow-gaging stations, results of aquifer tests, and water-level data collected over a 40-year timeframe. The model was developed as a steady-state three-dimensional simulation. Initially the model was calibrated to average hydrologic conditions based on long-term water-level and streamflow data available for the study area. Mean and median measured streamflow for the Opequon Creek near Martinsburg, W.Va., station are 604,384 and $349,907 \mathrm{~m}^{3} / \mathrm{d}$, respectively. The simulated base flow of $432,834 \mathrm{~m}^{3} / \mathrm{d}$ for Opequon Creek near Martinsburg falls between the mean and median flow conditions measured for the watershed. Simulated subwatershed base-flow yield for average conditions ranged from 0 to $2,643 \mathrm{~m}^{3} / \mathrm{d} / \mathrm{km}^{2}$, and was estimated to be $557 \mathrm{~m}^{3} / \mathrm{d} / \mathrm{km}^{2}$ over the entire Opequon Creek watershed area.

The drought of November 1998 through February 2000 was simulated by reducing recharge in the initial model by 40 percent to values of 90,168 , and $234 \mathrm{~mm} / \mathrm{yr}$, rates that approximate the recharge during the prolonged 16-month drought. Mean and median measured streamflow for the Opequon Creek near Martinsburg streamflow-gaging station during the 16-month drought were 341,098 and $216,551 \mathrm{~m}^{3} / \mathrm{d}$, respectively. The simulated drought base-flow discharge for the Opequon Creek near Martinsburg station of $252,356 \mathrm{~m}^{3} / \mathrm{d}$ falls between the mean and median streamflow measured during the 16-month drought. Recharge over the entire watershed during the simulated drought was $413 \mathrm{~m}^{3} / \mathrm{d} / \mathrm{km}^{2}$, and was $388 \mathrm{~m}^{3} / \mathrm{d} / \mathrm{km}^{2}$ at the Martinsburg station. Simulated subwatershed base-flow yield for drought conditions ranged from 0 to $1,865 \mathrm{~m}^{3} / \mathrm{d} / \mathrm{km}^{2}$ and was $327 \mathrm{~m}^{3} / \mathrm{d} / \mathrm{km}^{2}$ over the entire Opequon Creek watershed area.

Water budgets for the simulation indicate a substantial component of discharge to the Potomac River through direct ground-water discharge. This phenomenon has long been suspected but has now been quantified. During average conditions, approximately $564,176 \mathrm{~m}^{3} / \mathrm{d}\left(6.53 \mathrm{~m}^{3} / \mathrm{s}\right)$ of base flow discharges to the Potomac River. An additional 124,379 $\mathrm{m}^{3} / \mathrm{d}$ $\left(1.44 \mathrm{~m}^{3} / \mathrm{s}\right)$ of ground water is also estimated to discharge directly to the Potomac River, and represents approximately 18 percent of the total discharge to the Potomac River.

Analyses of head equipotential lines with respect to geologic structures such as thrust and cross-strike faults illustrate that surface and ground water over a very broad area are funneled along the faults, especially where the faults are in close proximity to low-permeability bedrock such as the Conococheague Limestone and Martinsburg Formation. These structural and lithologic controls are responsible for many of the large springs in the Opequon Creek watershed area. Ground water discharges to the Potomac River through numerous strike-parallel faults or fracture zones. Although this process was suspected, it had not been fully documented. Although the simulation provides only an initial estimate of ground-water discharge to the Potomac River, it does at least indicate that this discharge is a mathematically reasonable hypothesis.

Although the water budget and potentiometric surfaces estimated by the model are reasonable, the accuracy of the model has some limitations. Therefore, water-budget information for the subwatersheds should be regarded as estimates 
only because of the lack of calibration data specific to the subwatersheds and the hydrologic conditions simulated. Differences between simulated and actual recharge, base-flow yields, and channel gains and losses are possible. In addition, it is difficult to accurately estimate spring discharge; therefore, the model was calibrated to base-flow stream discharge rather than spring flow.

\section{References Cited}

Beiber, P.B., 1961, Ground-water features of Berkeley and Jefferson Counties, West Virginia: West Virginia Geological Survey Bulletin 21, 81 p.

Boughton, C.J., and McCoy, K.J., 2006, Hydrogeology, aquifer geochemistry, and ground-water quality in Morgan County, West Virginia: U.S. Geological Survey Scientific Investigations Report 2006-5198, 56 p.

Burbey, T.J., 2003, Water management model-Frederick County Sanitation Authority: Blacksburg, Virginia, Virginia Polytechnic Institute and State University, $11 \mathrm{p}$.

Cornell University, 2008, West Virginia drought periods: Accessed April 18, 2008, at url http://www.nrcc.cornell.edu/ drought/WV_drought_periods.html

Early, J.S., 2005, A regional scale steady-state groundwater flow model of a steeply-dipping karst aquifer, Shenandoah Valley of West Virginia-Virginia: Unpublished master's thesis, Morgantown, West Virginia, West Virginia University, $105 \mathrm{p}$.

Dean, S.L., Lessing, P., and Kulander, B.R., 1990, Geology of the Berryville, Charles Town, Harpers Ferry, Middleway, and Round Hill quadrangles, Berkeley and Jefferson Counties, West Virginia: West Virginia Geologic and Economic Survey, Map-W.Va.35, scale 1:24,000, 1 sheet.

Evaldi, R.D., and Paybins, K.S., 2006a, Base-flow yields of watersheds in the Berkeley County area, West Virginia: U.S. Geological Survey Data Series 216, 4 p.

Evaldi, R.D., and Paybins, K.S., 2006b, Channel gains and losses in the Opequon Creek watershed of West Virginia, July 25-28, 2005: U.S. Geological Survey Data Series 179, $7 \mathrm{p}$.

Fenneman, N.M., 1938, Physiography of Eastern United States: New York, McGraw-Hill, 534 p.

Frazier, D.A., Jascott, B.J., and McGowan, M.J., 1988, Construction of experimental research ponds at the National Fisheries Center, Leetown, West Virginia: Denver, Colorado, Merrick \& Company, Report submitted to the U.S. Fish and Wildlife Service, $22 \mathrm{p}$.
Gary, M., McAfee, Robert, Jr., and Wolf, C., 1973, Glossary of geology: Washington, D.C., American Geological Institute, 805 p., 1 app.

Graeff, G.D., Jr., 1953, Ground-water conditions in a typical limestone area near Inwood, West Virginia: U.S. Geological Survey Open-File Report 53-78, 6 p.

Harbaugh, A.W., Banta, E.R., Hill, M.C., and McDonald, M.G., 2000, MODFLOW-2000, the U.S. Geological Survey modular ground-water model-User guide to modularization concepts and the ground-water flow process: U.S. Geological Survey Open-File Report 00-92, 121 p.

Harlow, G.E., Jr., Orndorff, R.C., Nelms, D.L., Weary, D.J., and Moberg, R.M., 2005, Hydrogeology and ground-water availability in the carbonate aquifer system of Frederick County, Virginia: U.S. Geological Survey Scientific Investigations Report 2005-5161, $30 \mathrm{p}$

Harris, A.G., Stamm, N.R., Weary, D.J., Repetski, J.E., Stamm, R.G., and Parker, R.A., 1994, Conodont color alteration index (CAI) map and conodont-based age determination for the Winchester 30' X 60' quadrangle and adjacent areas, Virginia, West Virginia, and Maryland: U.S. Geological Survey Miscellaneous Field Studies Map MF-2239, scale 1:100,000.

Hobba, W.A., Jr., 1981, Ground-water hydrology of Jefferson County, West Virginia: West Virginia Geological and Economic Survey Environmental Geology Bulletin EGB-16, $21 \mathrm{p}$.

Hobba, W.A., Jr., 1976, Ground-water hydrology of Berkeley County, West Virginia: West Virginia Geological and Economic Survey Environmental Geology Bulletin 13, $21 \mathrm{p}$.

Hobba, W.A., Jr., Friel, E.A., and Chisholm, J.L., 1972, Water resources of the Potomac River basin, West Virginia: West Virginia Geologic and Economic Survey, River Basin Bulletin $3,110 \mathrm{p}$.

Hoover, D.B., Frischknecht, F.C., and Tippens, C., 1976, Audio-magnetotelluric soundings as a reconnaissance exploration technique in Long Valley, California: Washington, D.C., American Geophysical Union, Journal of Geophysical Research, v. 81, no. 5, p. 801-809.

Jeffords, R.M., 1945a, Water supply at Martinsburg, West Virginia: U.S. Geological Survey unnumbered report, 8 p.

Jeffords, R.M., 1945b, Water supply at the Newton D. Baker Hospital near Martinsburg, West Virginia: U.S. Geological Survey unnumbered report, $12 \mathrm{p}$.

Jones, W.K., 1997, Karst hydrology atlas of West Virginia: Karst Waters Institute Special Publication no. 4, 111 p. 
Jones, W.K., 1991, The carbonate aquifer of the northern Shenandoah Valley of Virginia and West Virginia: in Kastning, E.H., and Kastning, K.M., eds., Proceedings Appalachian Karst Symposium: Huntsville, Alabama, National Speleological Society, p. 217-222.

Jones, W.K., and Deike, G.H., III, 1981, A hydrogeologic study of the watershed of the National Fisheries Center at Leetown, West Virginia: Frankford, West Virginia, Environmental Data, unpublished report prepared for the U.S. Fish and Wildlife Service, $84 \mathrm{p}$.

Kozar, M.D., McCoy, K.J., Weary, D.J., Field, M.S., Pierce, H.A., Schill, W.B., and Young, J.A., 2008, Hydrogeology and water quality of the Leetown area, West Virginia: U.S. Geological Survey Open-File Report 2007-1358, 212 p.

Kozar, M.D., Weary, D.J., Paybins, K.S., and Pierce, H.A., 2007, Hydrogeologic setting and ground-water flow in the Leetown area, West Virginia: U.S. Geological Survey Scientific Investigations Report 2006-5066, 80 p.

Kozar, M.D., and Mathes, M.V., 2001, Aquifer characteristics data for West Virginia: U.S. Geological Survey WaterResources Investigations Report 01-4036, 74 p.

Kozar, M.D., Hobba, W.A., and Macy, J.A., 1991, Geohydrology, water availability, and water quality of Jefferson County, West Virginia, with emphasis on the carbonate area: U.S. Geological Survey Water-Resources Investigations Report 90-4118, 93 p.

Lindgren, R.J., Dutton, A.R., Hovorka, S.D., Worthington, S.R.H., and Painter, S., 2005, Conceptualization and simulation of the Edwards aquifer, San Antonio region, Texas: in Kuniansky, E.L., ed., U.S. Geological Survey Karst Interest Group Proceedings, Rapid City, South Dakota, September 12-15, 2005: U.S. Geological Survey Scientific Investigations Report 2005-5160, p. 48-57.

McCoy, K.J., and Kozar, M.D., 2007a, Relation of chlorofluorocarbon ground-water age dates to water quality in aquifers of West Virginia: U.S. Geological Survey Scientific Investigations Report 2006-5221, 36 p.

McCoy, K.J., and Kozar, M.D., 2007b, Use of sinkhole and specific capacity distributions to assess vertical gradients in a karst aquifer: Environmental Geology, DOI 10.1007/ s00254-007-0889-1, $15 \mathrm{p}$.

McCoy, K.J., Podwysocki, M.H., Crider, E.A., and Weary, D.J., 2005a, Fracture trace map and single-well aquifer test results in a carbonate aquifer in Berkeley County, West Virginia: U.S. Geological Survey Open-File Report 2005-1040, 1 pl.
McCoy, K.J., Podwysocki, M.H., Crider, E.A., and Weary, D.J., 2005b, Fracture trace map and single-well aquifer test results in a carbonate aquifer in Jefferson County, West Virginia: U.S. Geological Survey Open-File Report 2005-1407, 1 pl.

National Oceanic and Atmospheric Administration, U.S. Department of Commerce, 2002, Monthly station normals of temperature, precipitation, and heating and cooling degree days 1971-2000, for the State of Virginia: National Oceanic and Atmospheric Administration-Climatography of the United States publication No. 81, section 44, 24 p.

National Oceanic and Atmospheric Administration, U.S. Department of Commerce, 2002, Monthly station normals of temperature, precipitation, and heating and cooling degree days 1971-2000, for the State of West Virginia: National Oceanic and Atmospheric Administration Climatography of the United States publication No. 81, section $46,23 \mathrm{p}$.

National Oceanic and Atmospheric Administration, U.S. Department of Commerce, 2008, Historical climate summaries: Southeast Regional Climate Center online data accessed November 5, 2008, at url http://www.sercc.com/ climateinfo/historical/historical.html

Orndorff, R.C., Epstein, J.B., and McDowell, R.C., 1999, Geologic map of the Middletown Quadrangle, Frederick, Shenandoah, and Warren Counties, Virginia: U.S. Geological Survey Geologic Quadrangle Map 1803, 1 pl.

Orndorff, R.C.,1992, Tectonic significance of cross-strike faults in the central Appalachian Great Valley of Maryland and West Virginia: Southeastern Geology, v. 32, no. 4, p. 197-214.

Pollock, D.W., 1998, MODPATH—Documentation of computer programs to compute and display pathlines using results from U.S. Geological Survey modular three-dimensional finite-difference ground-water flow model: U.S. Geological Survey Open-File Report 89-381, 188 p.

Putnam, L.D., and Long, A.J., 2005, Simulating ground-water flow in the karstic Madison aquifer using a porous media model: in Kuniansky, E.L., ed., U.S. Geological Survey Karst Interest Group Proceedings, Rapid City, South Dakota, September 12-15, 2005: U.S. Geological Survey Scientific Investigations Report 2005-5160, p. 46.

Quinn, J.J., Tomasko, D.D., and Kuiper, J.A., 2005a, The role of MODFLOW in numerical modeling of karst flow systems: in Kuniansky, E.L., ed., U.S. Geological Survey Karst Interest Group Proceedings, Rapid City, South Dakota, September 12-15, 2005: U.S. Geological Survey Scientific Investigations Report 2005-5160, p. 58-62. 
Quinn, J.J., Tomasko, D.D., and Kuiper, J.A., 2005b, Modeling complex flow in a karst aquifer: in Sedimentary Geology, v. 184, issues 3-4, p. 343-351.

Rutledge, A.T., 1998, Computer programs for describing the recession of ground-water discharge and for estimating mean ground-water recharge and discharge from streamflow records-Update: U.S. Geological Survey Water-Resources Investigations Report 98-4148, 43 p.

Shultz, R.A., Hobba, W.A., and Kozar, M.D., 1995, Geohydrology and ground-water quality of Berkeley County, West Virginia, with emphasis on the carbonate area: U.S. Geological Survey Water-Resources Investigations Report 93-4073, 88 p.

Southworth, S., Drake, A.A., Jr., Brezinski, D.K., Wintsch, R.P., Kunk, M.J., Aleinikoff, J.N., Naeser, C.W., and Naeser, N.D., 2006, Central Appalachian Piedmont and Blue Ridge tectonic transect, Potomac River corridor: Geological Society of America field trip guidebook 8.

Taylor, L.E., 1974, Bedrock geology and its influence on ground-water resources in the Hedgesville and Williamsport 7-1/2 minute quadrangles, Berkeley County, West Virginia: unpublished master's thesis, Toledo, Ohio, University of Toledo, 82 p.

Unger, T., Davis, R.K., Brahana, J.V., and Thoma, G., 2003, Structural controls to successfully model groundwater flow within the mantled karst of the Savoy Experimental Watershed, Northwest Arkansas: 2003 Annual Geological Society of America meeting abstract, Seattle, Washington, Paper no. $103-13,1$ p.

U.S. Geological Survey, 2008a, Water data report 2007Opequon Creek near Berryville, Virginia: U.S. Geological Survey Water Data Report accessed July 15, 2008, at http://wdr.water.usgs.gov/wy2007/pdfs/01615000.2007.pdf
U.S. Geological Survey, 2008b, Water Data Report 2007-Opequon Creek near Martinsburg, West Virginia: U.S. Geological Survey Water Data Report accessed July 15, 2008, at http://wdr.water.usgs.gov/wy2007/pdfs/01616500.2007.pdf

U.S. Geological Survey, 2008c, Water Data Report 2007-Opequon Creek near Stephens City, Virginia: U.S. Geological Survey Water Data Report accessed July 15, 2008, at http://wdr.water.usgs.gov/wy2007/pdfs/01614830.2007.pdf

Ward, S.M., Taylor, B.C., and Crosby, G.R., 2000, Water resources data for West Virginia, water year 1999: U.S. Geological Survey Water Data Report W.VA.-99-1, 305 p.

Ward, S.M., Taylor, B.C., and Crosby, 2001, Water resources data for West Virginia, water year 2000: U.S. Geological Survey Water Data Report W.VA.-00-1, 262 p.

Ward, S.M., Taylor, B.C., and Crosby, 2006, Water resources data for West Virginia, water year 2005: U.S. Geological Survey Water Data Report W.VA.-05-1, 278 p.

Waterloo Hydrogeologic, Inc., 2004, Visual MODFLOW, v. 4.0, User's manual: Waterloo, Ontario, Canada, Waterloo Hydrogeologic, Inc., 567 p.

White, W.B., 2002, Karst hydrology: Recent developments and open questions: Engineering Geology, v. 65, p. 85-105.

Wolfe, W.J., Haugh, C.J., Webbers, Ank, and Diehl, T.H., 1997, Preliminary conceptual models of the occurrence, fate, and transport of chlorinated solvents in karst regions of Tennessee: U.S. Geological Survey Water-Resources Investigations Report 97-4097, 80 p.

Yager, R.M., Southworth, Scott, and Voss, C.I., 2008, Simulation of ground-water flow in the Shenandoah Valley, Virginia and West Virginia, using variable-direction anisotropy in hydraulic conductivity to represent bedrock structure: U.S. Geological Survey Scientific Investigations Report 2008-5002, 54 p. 
Appendixes 
Appendix 1. Water levels and map coordinates for wells used in calibration of the ground-water flow model of the Opequon Creek watershed area, Virginia and West Virginia.

[USGS, U.S. Geological Survey; UTM, Universal Transverse Mercator projection; m, meters; NAVD 88, North American Vertical Datum of 1988]

\begin{tabular}{|c|c|c|c|c|c|}
\hline $\begin{array}{c}\text { Report identification } \\
\text { number }\end{array}$ & $\begin{array}{l}\text { USGS local } \\
\text { well number }\end{array}$ & $\begin{array}{l}\text { UTM Easting } \\
(\mathrm{m})\end{array}$ & $\begin{array}{l}\text { UTM Northing } \\
\text { (m) }\end{array}$ & $\begin{array}{c}\text { Observed water } \\
\text { level } \\
\text { (m above NAVD 88) }\end{array}$ & $\begin{array}{c}\text { Simulated water } \\
\text { level }\end{array}$ \\
\hline 1 & $45 \mathrm{~W} 15$ & 224695 & 4332978 & 213.3 & 213.9 \\
\hline 2 & $45 \times 2$ & 224593 & 4335510 & 217.9 & 219.1 \\
\hline 3 & $45 \times 3$ & 219458 & 4339287 & 252.1 & 242.0 \\
\hline 4 & $45 X 6$ & 221816 & 4343063 & 257.1 & 247.3 \\
\hline 6 & $45 \times 8$ & 225916 & 4342605 & 222.2 & 222.5 \\
\hline 7 & $45 \times 12$ & 221181 & 4336346 & 230.3 & 230.2 \\
\hline 8 & $45 \times 13$ & 219716 & 4336217 & 243.5 & 235.7 \\
\hline 9 & $45 \times 14$ & 220960 & 4339322 & 243.6 & 236.0 \\
\hline 13 & $45 \times 20$ & 223411 & 4342232 & 238.5 & 230.6 \\
\hline 14 & $45 Y 2$ & 229466 & 4349961 & 211.5 & 200.4 \\
\hline 15 & $45 \mathrm{Y} 3$ & 229580 & 4350760 & 218.0 & 202.3 \\
\hline 16 & 46W 33 & 230276 & 4329512 & 182.3 & 190.1 \\
\hline 17 & 46W108 & 232627 & 4334216 & 184.0 & 183.5 \\
\hline 18 & 46W178 & 231079 & 4331051 & 183.0 & 186.8 \\
\hline 19 & 46W188 & 232038 & 4333216 & 186.6 & 184.4 \\
\hline 20 & $46 \times 1$ & 236386 & 4343011 & 164.6 & 171.8 \\
\hline 21 & $46 \times 13$ & 235636 & 4340011 & 173.0 & 176.6 \\
\hline 28 & $46 \times 28$ & 238061 & 4339250 & 179.8 & 180.0 \\
\hline 29 & $46 \times 31$ & 239984 & 4342149 & 170.7 & 178.2 \\
\hline 30 & $46 \times 33$ & 233855 & 4338527 & 192.9 & 173.2 \\
\hline 31 & $46 \times 34$ & 234088 & 4338303 & 192.6 & 176.3 \\
\hline 32 & $46 \times 35$ & 235573 & 4339581 & 170.7 & 177.1 \\
\hline 33 & $46 \times 38$ & 234242 & 4337897 & 192.0 & 178.4 \\
\hline 34 & $46 \times 39$ & 234386 & 4337892 & 186.5 & 178.6 \\
\hline 35 & $46 \times 42$ & 234086 & 4338242 & 188.4 & 176.5 \\
\hline 36 & $46 \times 48$ & 240055 & 4342116 & 169.8 & 178.4 \\
\hline 37 & $46 \times 50$ & 239955 & 4346318 & 161.5 & 168.1 \\
\hline 38 & $46 X 54$ & 239414 & 4340193 & 181.3 & 181.1 \\
\hline 39 & $46 \times 59$ & 235176 & 4338483 & 166.1 & 178.3 \\
\hline 40 & $46 \times 72$ & 239368 & 4340966 & 186.5 & 179.7 \\
\hline
\end{tabular}


Appendix 1. Water levels and map coordinates for wells used in calibration of the ground-water flow model of the Opequon Creek watershed area, Virginia and West Virginia._Continued

[USGS, U.S. Geological Survey; UTM, Universal Transverse Mercator projection; m, meters; NAVD 88, North American Vertical Datum of 1988]

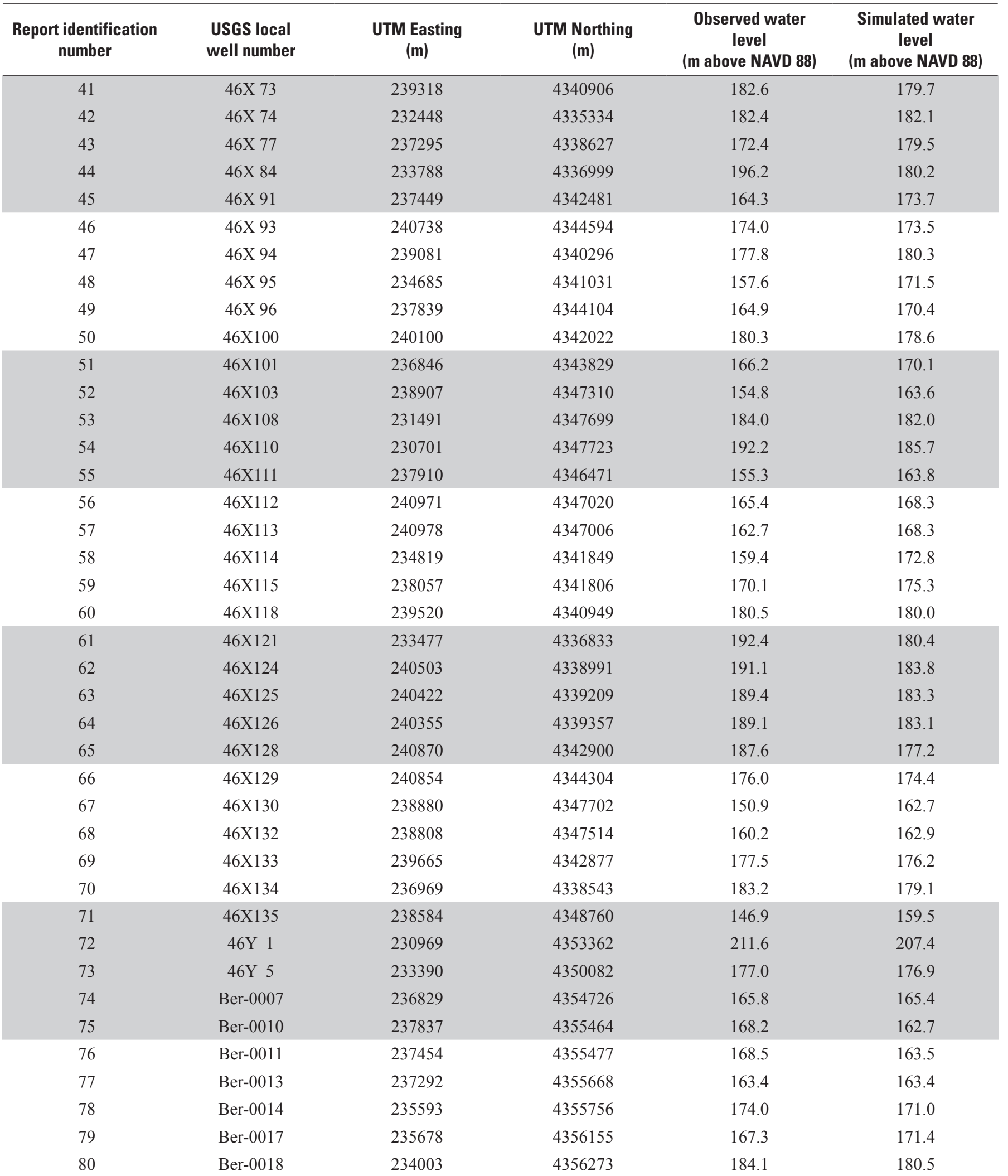


Appendix 1. Water levels and map coordinates for wells used in calibration of the ground-water flow model of the Opequon Creek watershed area, Virginia and West Virginia.-Continued

[USGS, U.S. Geological Survey; UTM, Universal Transverse Mercator projection; m, meters; NAVD 88, North American Vertical Datum of 1988]

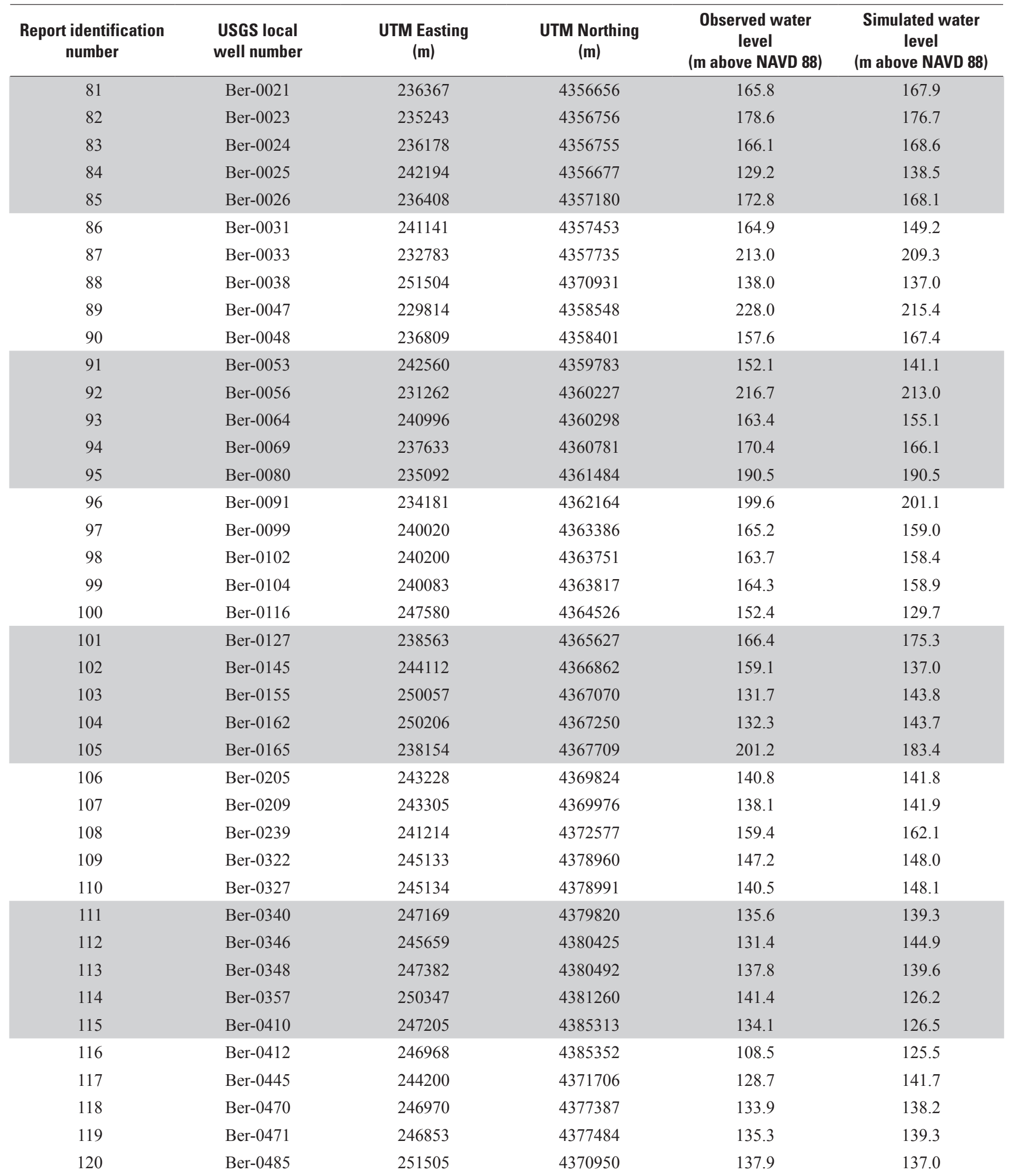


Appendix 1. Water levels and map coordinates for wells used in calibration of the ground-water flow model of the Opequon Creek watershed area, Virginia and West Virginia._Continued

[USGS, U.S. Geological Survey; UTM, Universal Transverse Mercator projection; m, meters; NAVD 88, North American Vertical Datum of 1988]

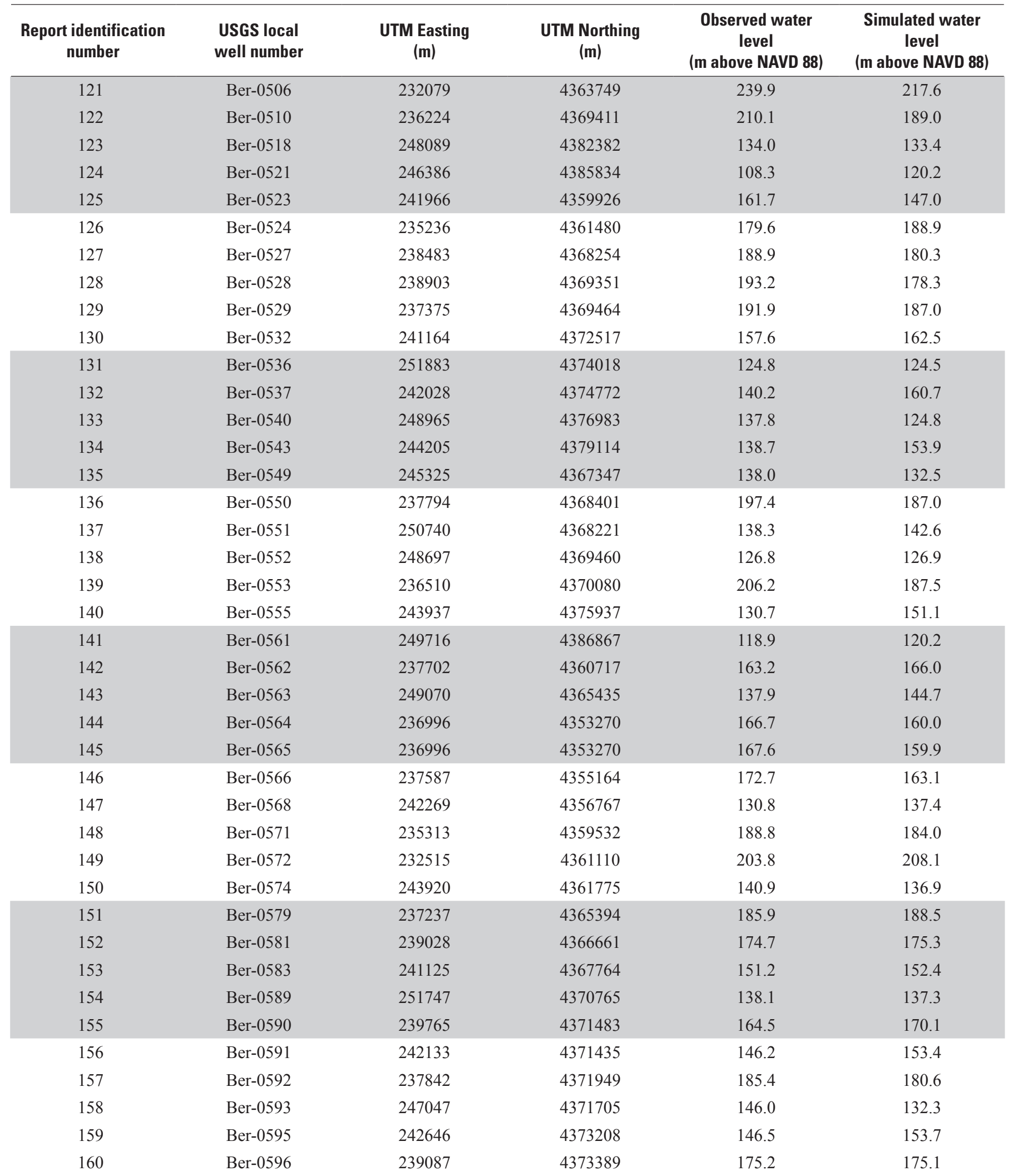


Appendix 1. Water levels and map coordinates for wells used in calibration of the ground-water flow model of the Opequon Creek watershed area, Virginia and West Virginia._Continued

[USGS, U.S. Geological Survey; UTM, Universal Transverse Mercator projection; m, meters; NAVD 88, North American Vertical Datum of 1988]

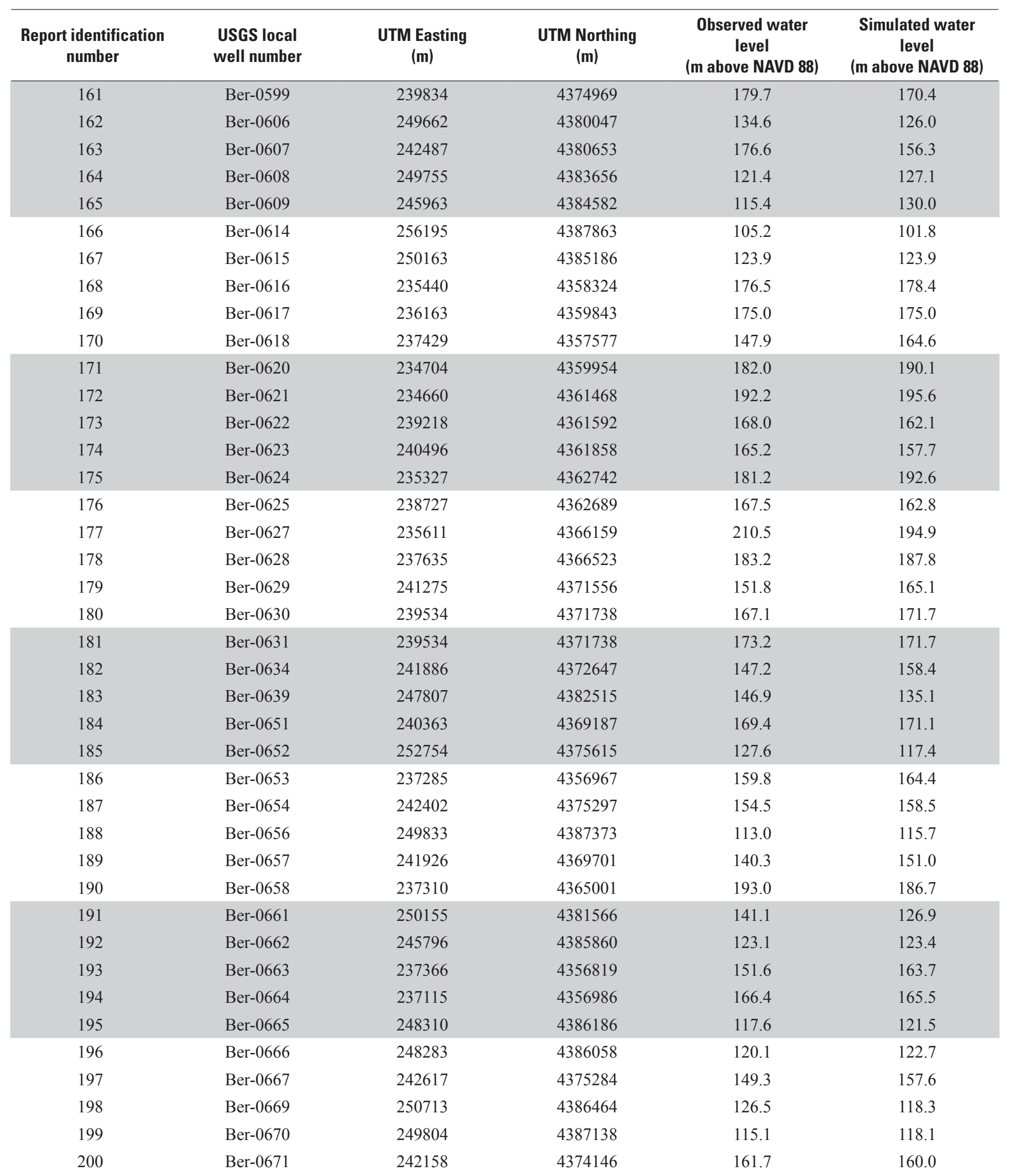


Appendix 1. Water levels and map coordinates for wells used in calibration of the ground-water flow model of the Opequon Creek watershed area, Virginia and West Virginia.-Continued

[USGS, U.S. Geological Survey; UTM, Universal Transverse Mercator projection; m, meters; NAVD 88, North American Vertical Datum of 1988]

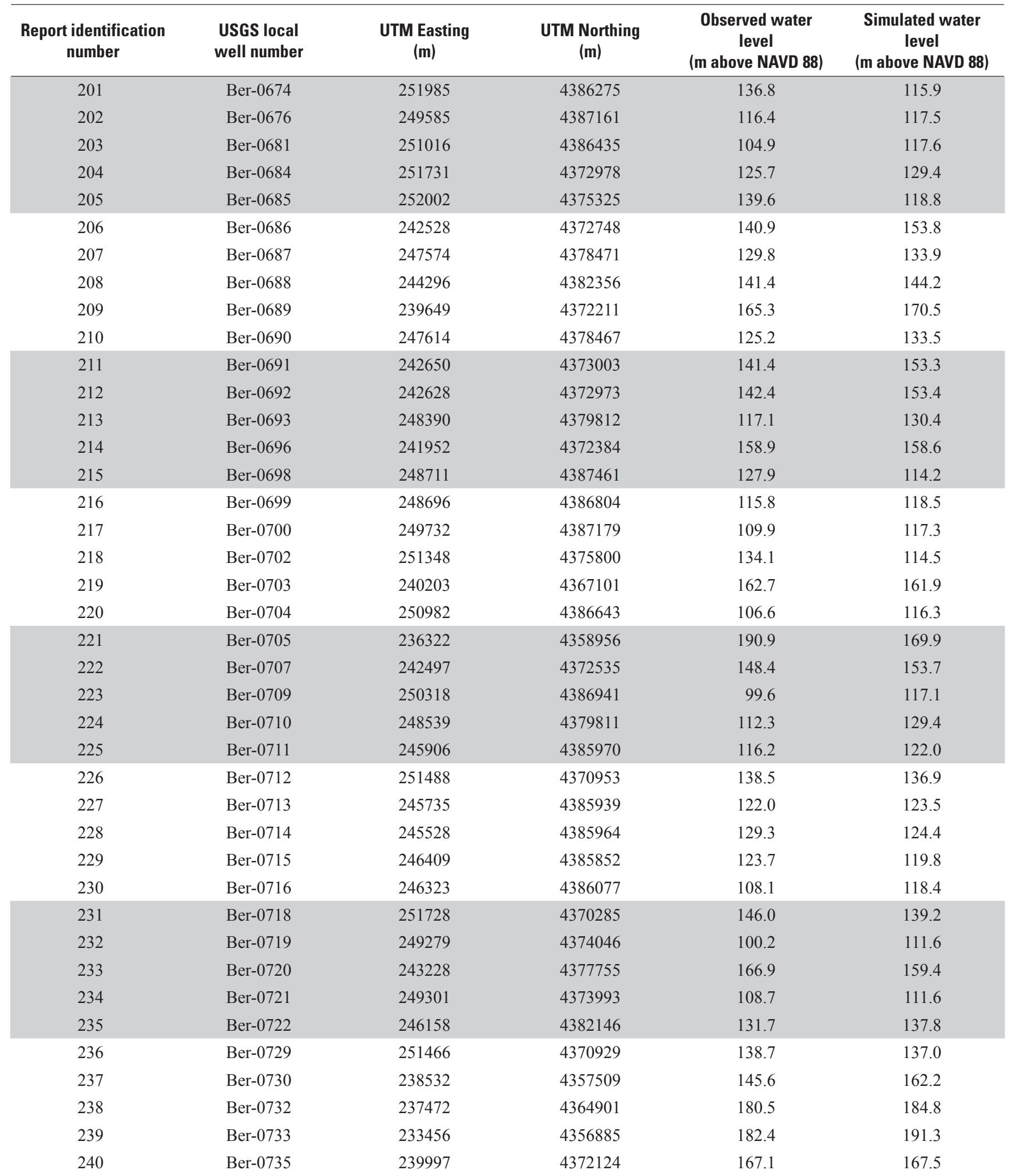


Appendix 1. Water levels and map coordinates for wells used in calibration of the ground-water flow model of the Opequon Creek watershed area, Virginia and West Virginia.-Continued

[USGS, U.S. Geological Survey; UTM, Universal Transverse Mercator projection; m, meters; NAVD 88, North American Vertical Datum of 1988]

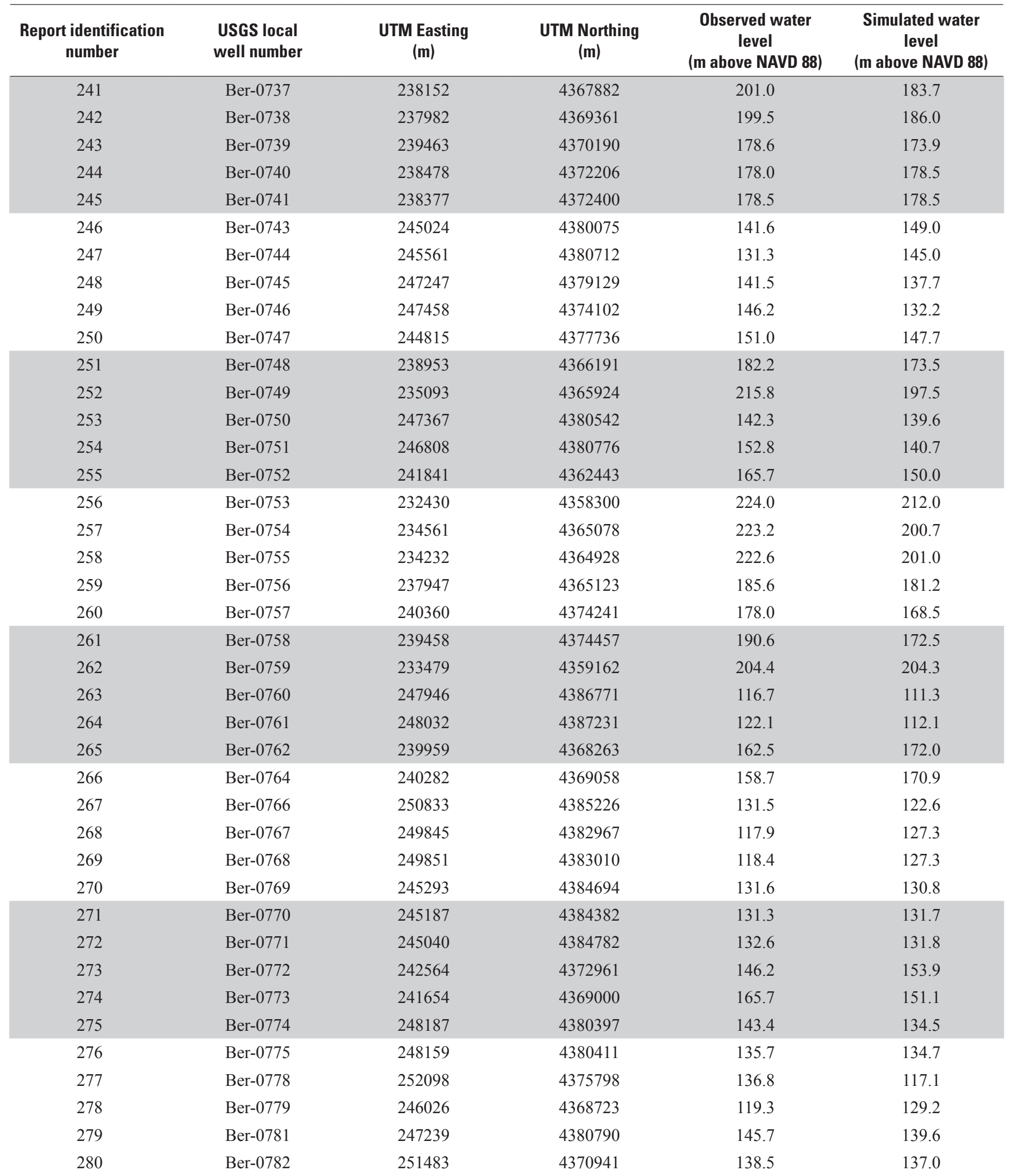


Appendix 1. Water levels and map coordinates for wells used in calibration of the ground-water flow model of the Opequon Creek watershed area, Virginia and West Virginia._Continued

[USGS, U.S. Geological Survey; UTM, Universal Transverse Mercator projection; m, meters; NAVD 88, North American Vertical Datum of 1988]

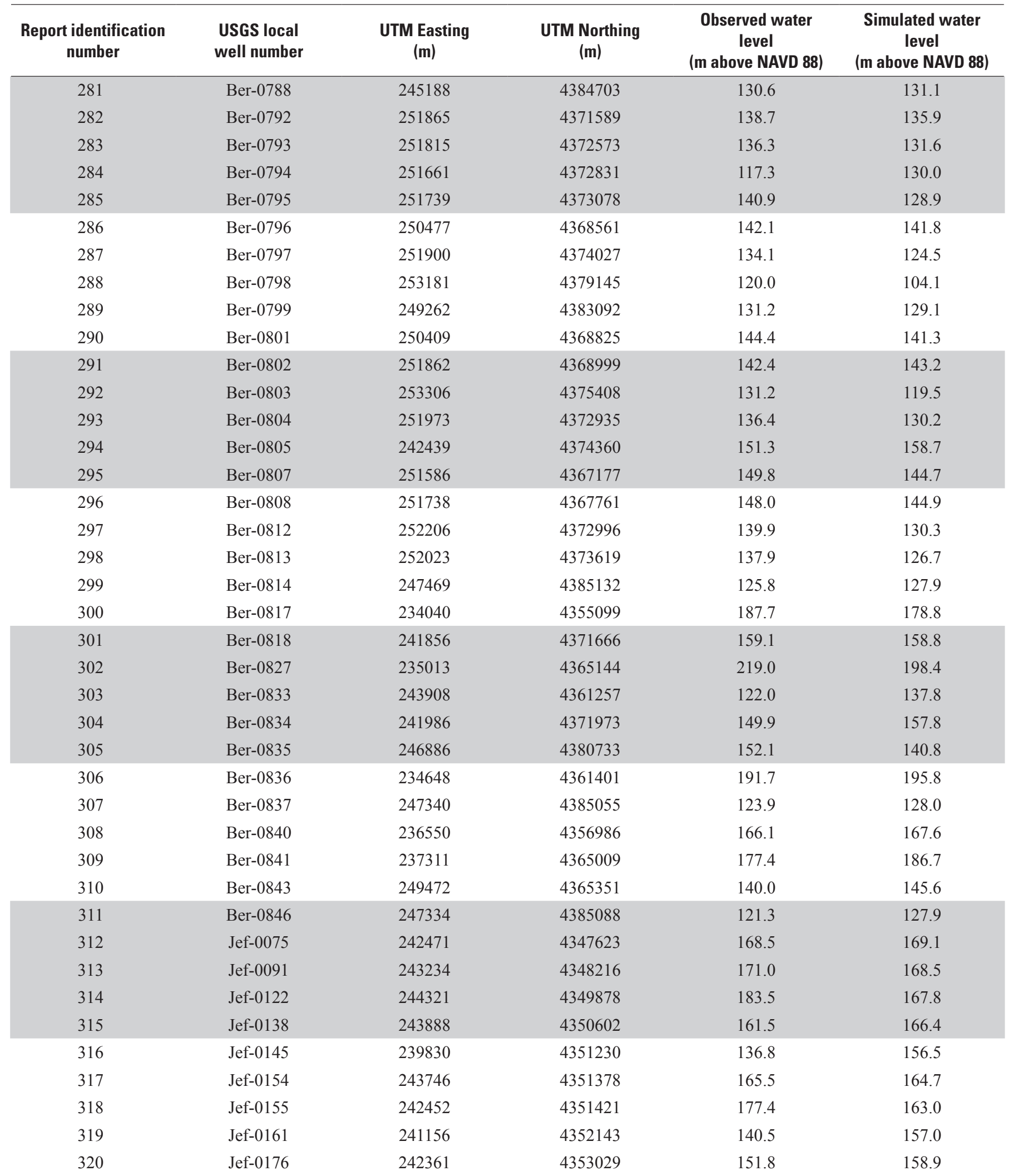


Appendix 1. Water levels and map coordinates for wells used in calibration of the ground-water flow model of the Opequon Creek watershed area, Virginia and West Virginia.-Continued

[USGS, U.S. Geological Survey; UTM, Universal Transverse Mercator projection; m, meters; NAVD 88, North American Vertical Datum of 1988]

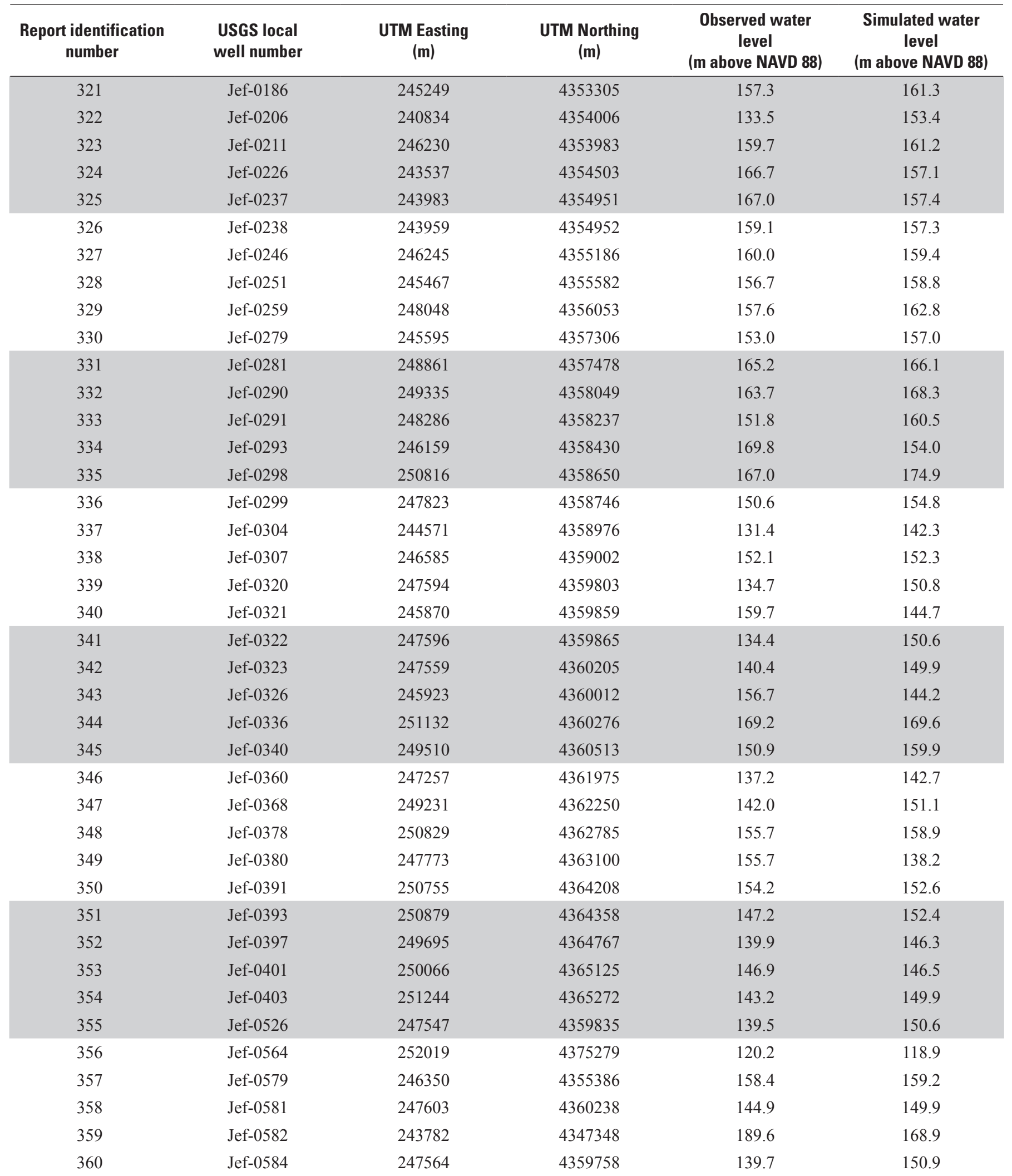


Appendix 1. Water levels and map coordinates for wells used in calibration of the ground-water flow model of the Opequon Creek watershed area, Virginia and West Virginia._Continued

[USGS, U.S. Geological Survey; UTM, Universal Transverse Mercator projection; m, meters; NAVD 88, North American Vertical Datum of 1988]

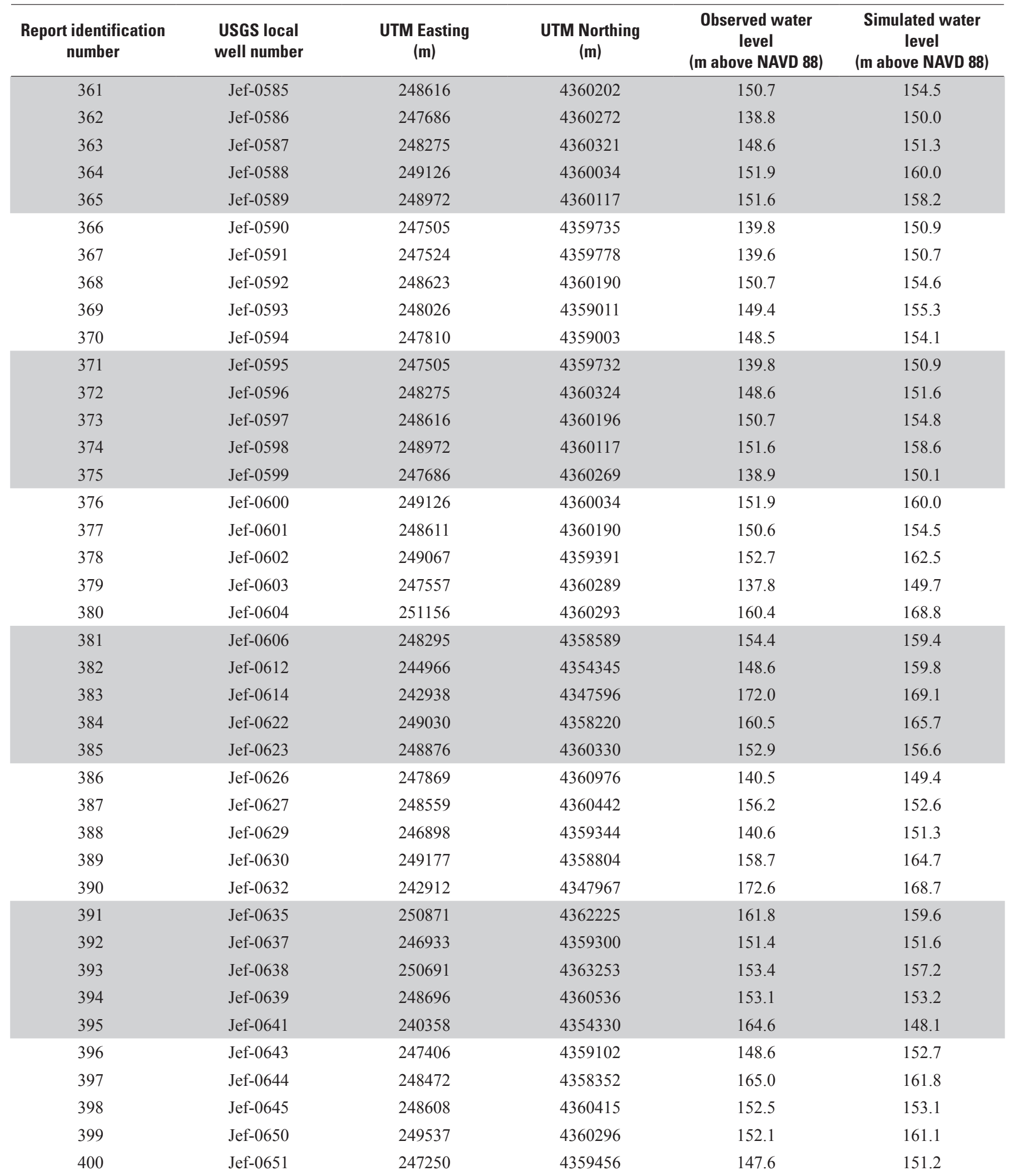


Appendix 1. Water levels and map coordinates for wells used in calibration of the ground-water flow model of the Opequon Creek watershed area, Virginia and West Virginia.-Continued

[USGS, U.S. Geological Survey; UTM, Universal Transverse Mercator projection; m, meters; NAVD 88, North American Vertical Datum of 1988]

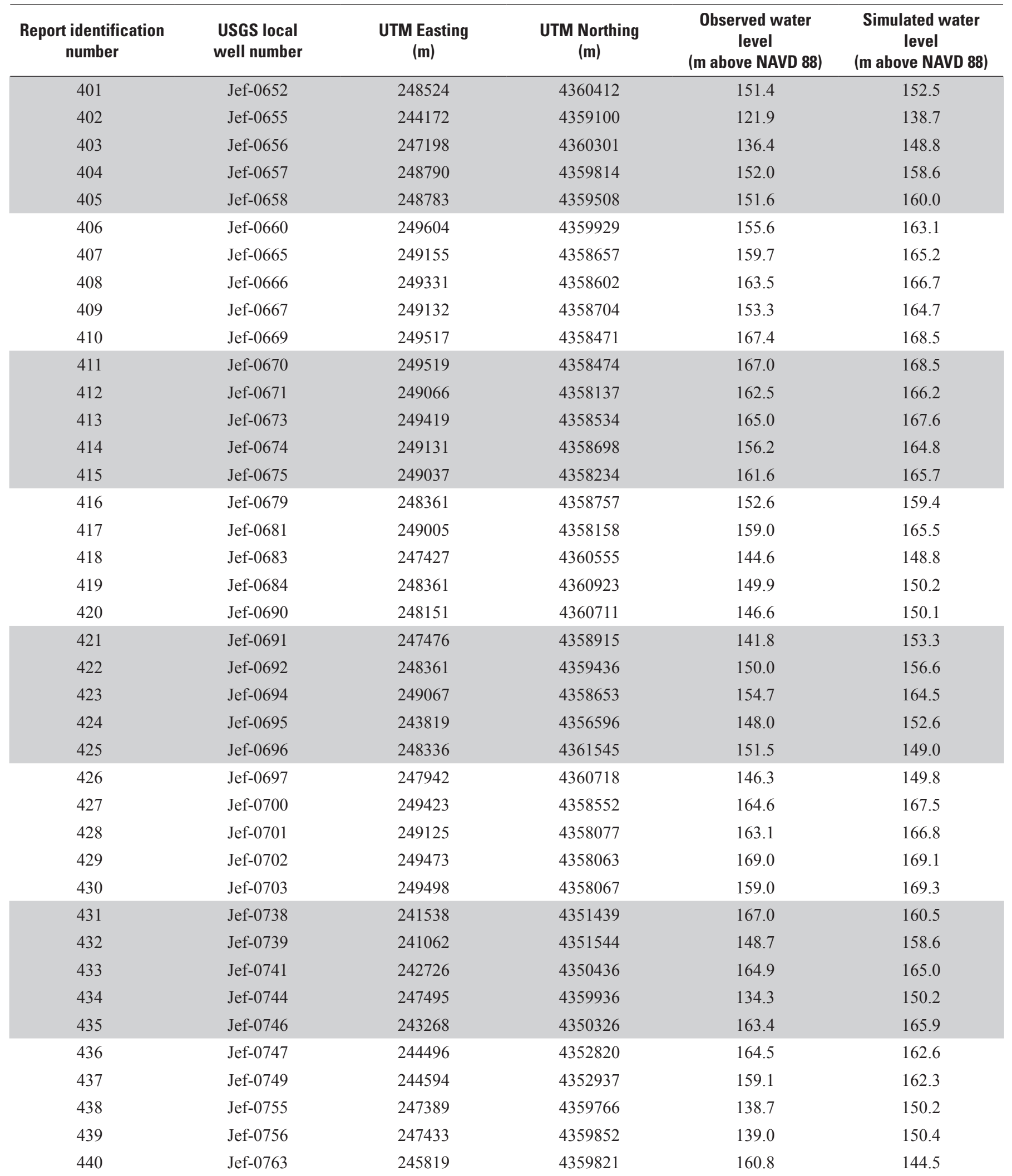


Appendix 1. Water levels and map coordinates for wells used in calibration of the ground-water flow model of the Opequon Creek watershed area, Virginia and West Virginia._Continued

[USGS, U.S. Geological Survey; UTM, Universal Transverse Mercator projection; m, meters; NAVD 88, North American Vertical Datum of 1988]

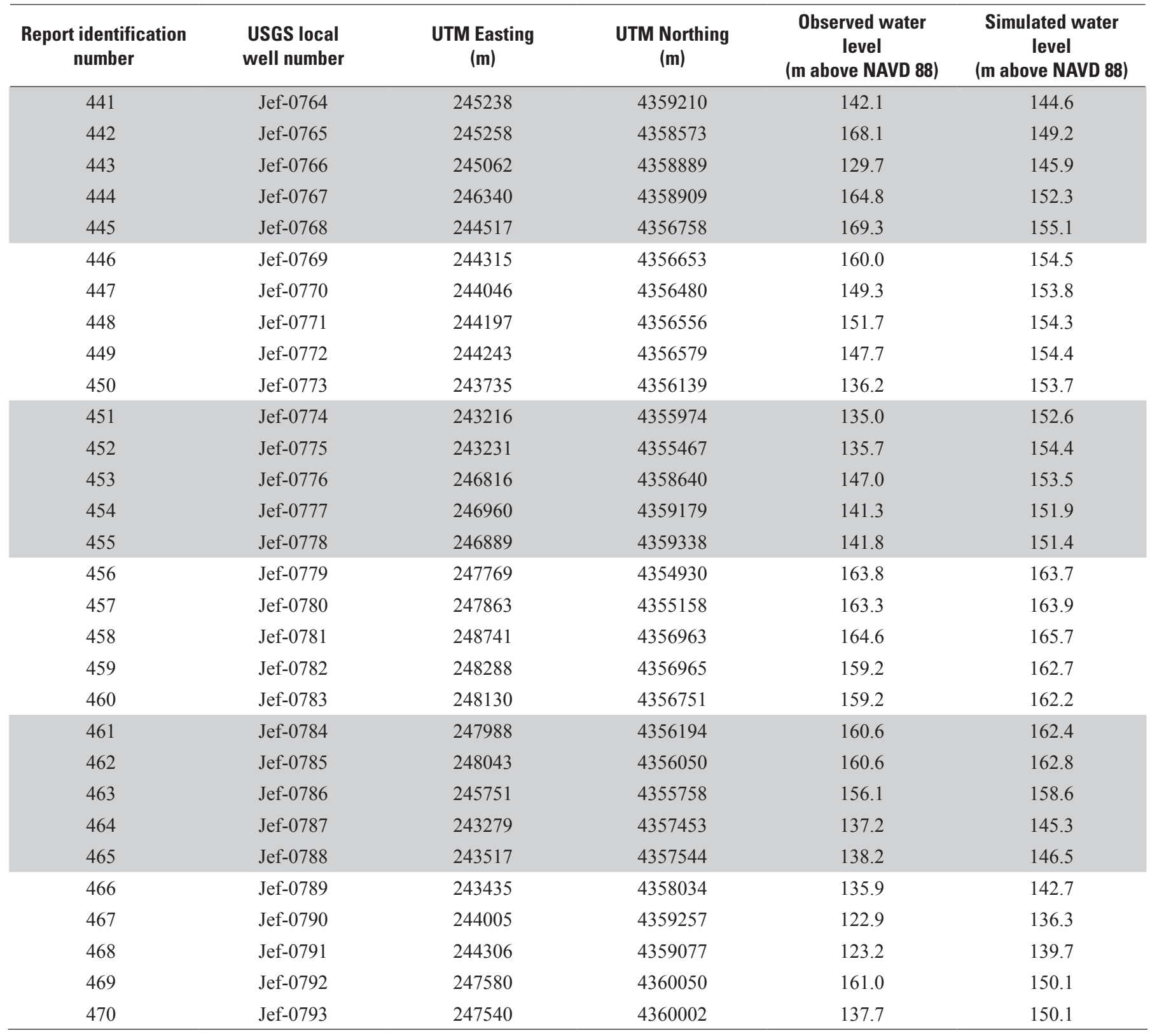


Appendix 2. Data for springs in the Opequon Creek watershed area, Virginia and West Virginia.

[UTM, Universal Transverse Mercator projection; NGVD 29, National Geodetic Vertical Datum of 1929; $\mathrm{m}^{3} / \mathrm{d}$, cubic meters per day; na, no data available]

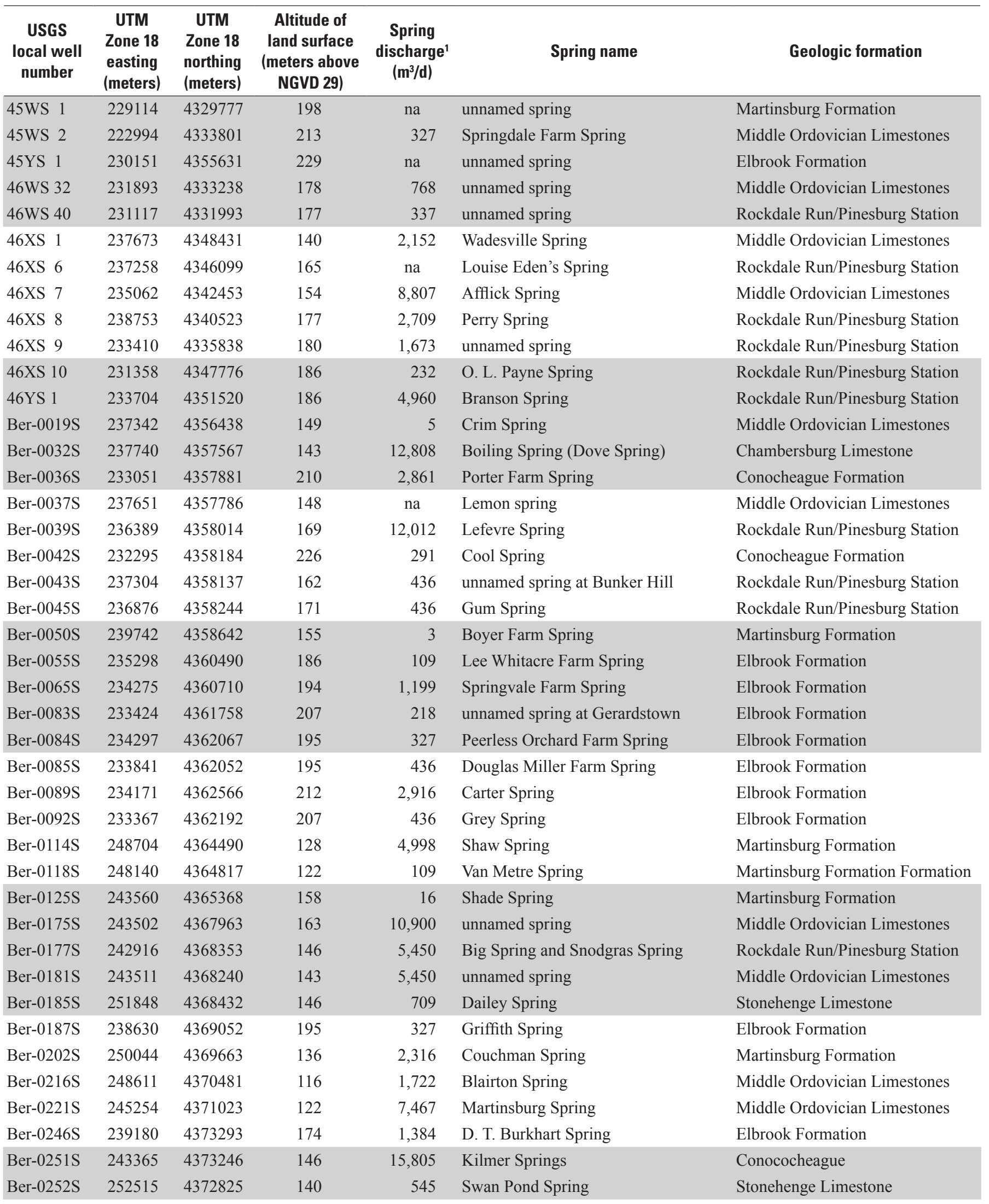


Appendix 2. Data for springs in the Opequon Creek watershed area, Virginia and West Virginia.—Continued

[UTM, Universal Transverse Mercator projection; NGVD 29, National Geodetic Vertical Datum of 1929; m³/d, cubic meters per day; na, no data available]

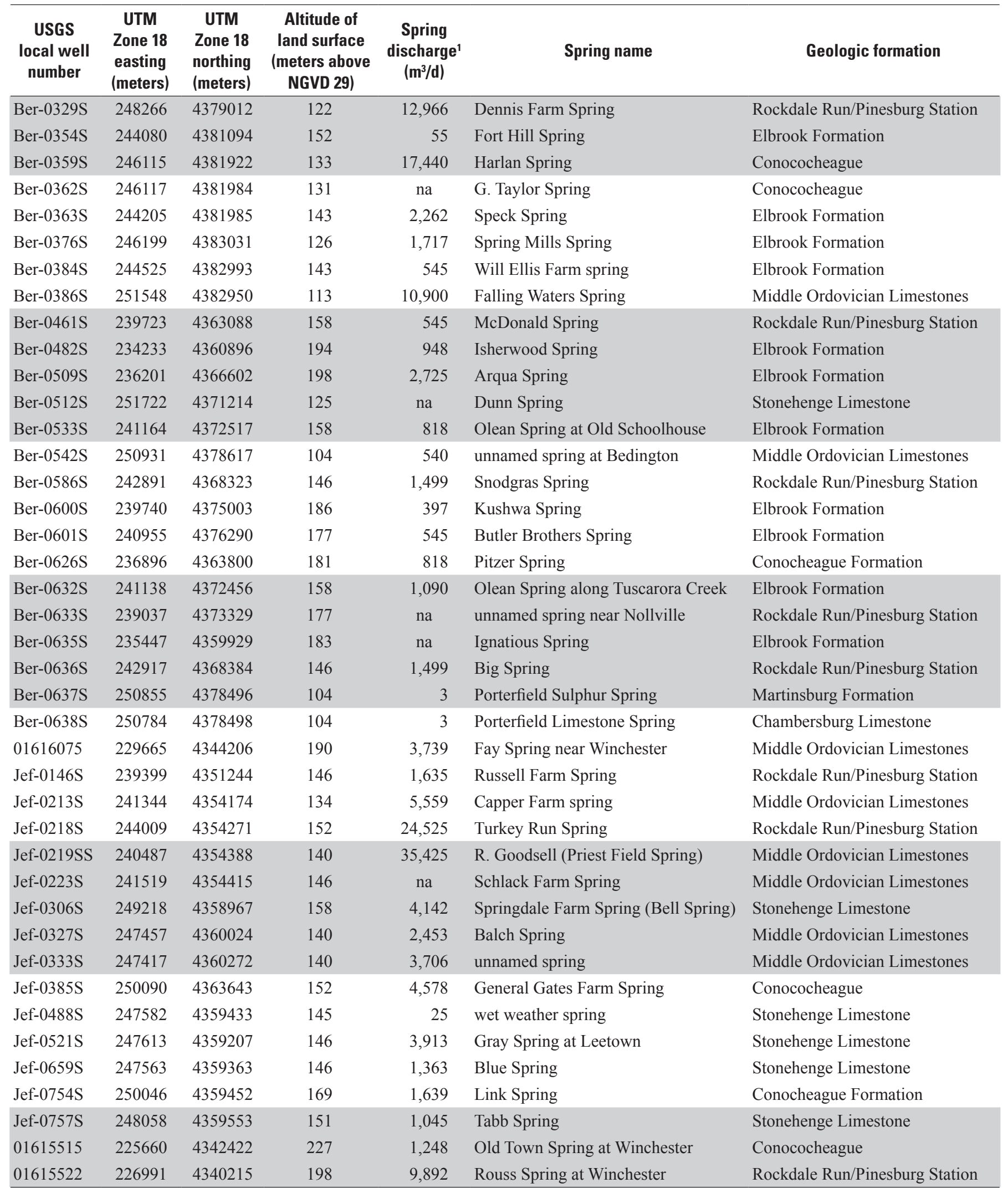

\footnotetext{
${ }^{1}$ Average (mean) discharge is presented for sites with more than one measured discharge.
} 

For additional information, write to:

Director

U.S. Geological Survey

West Virginia Water Science Center

11 Dunbar Street

Charleston, WV 25301

or visit our Web site at:

http://wv.usgs.gov/

Document prepared by the West Trenton Publishing Service Center 
